
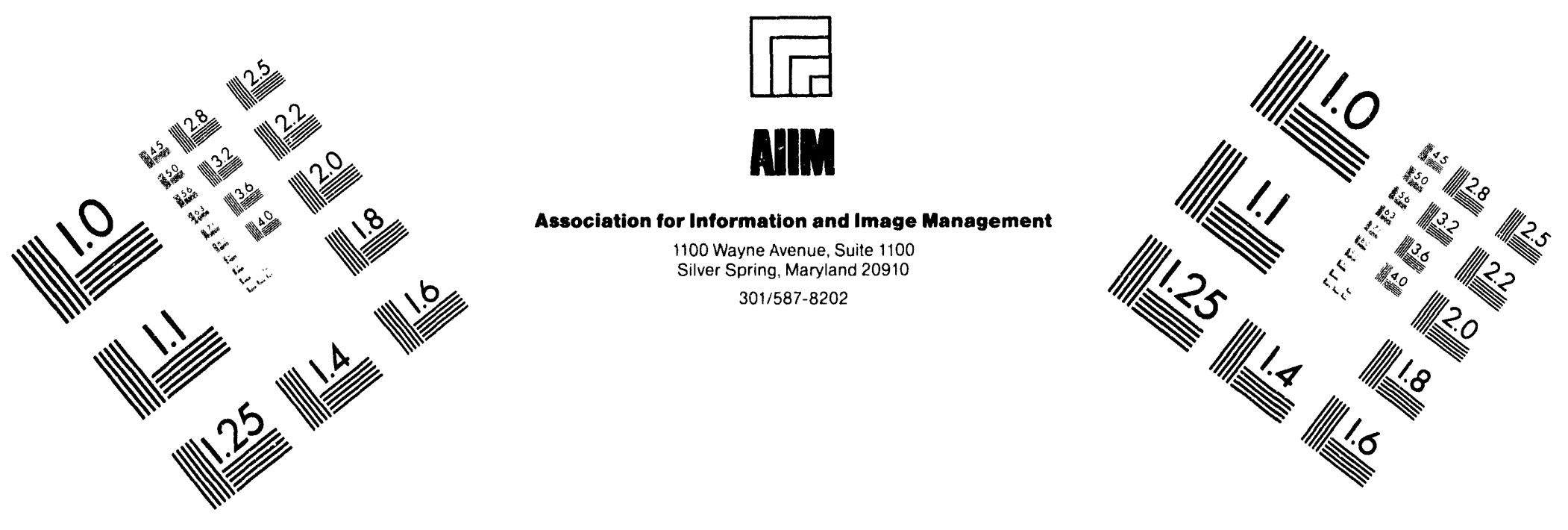

\title{
Centimeter
}

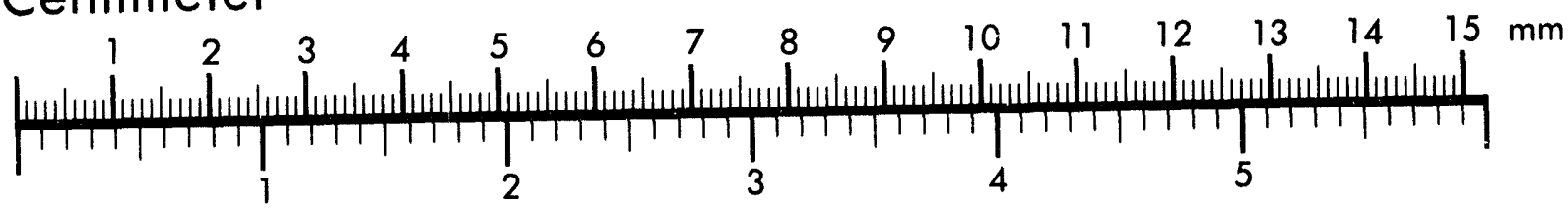
Inches
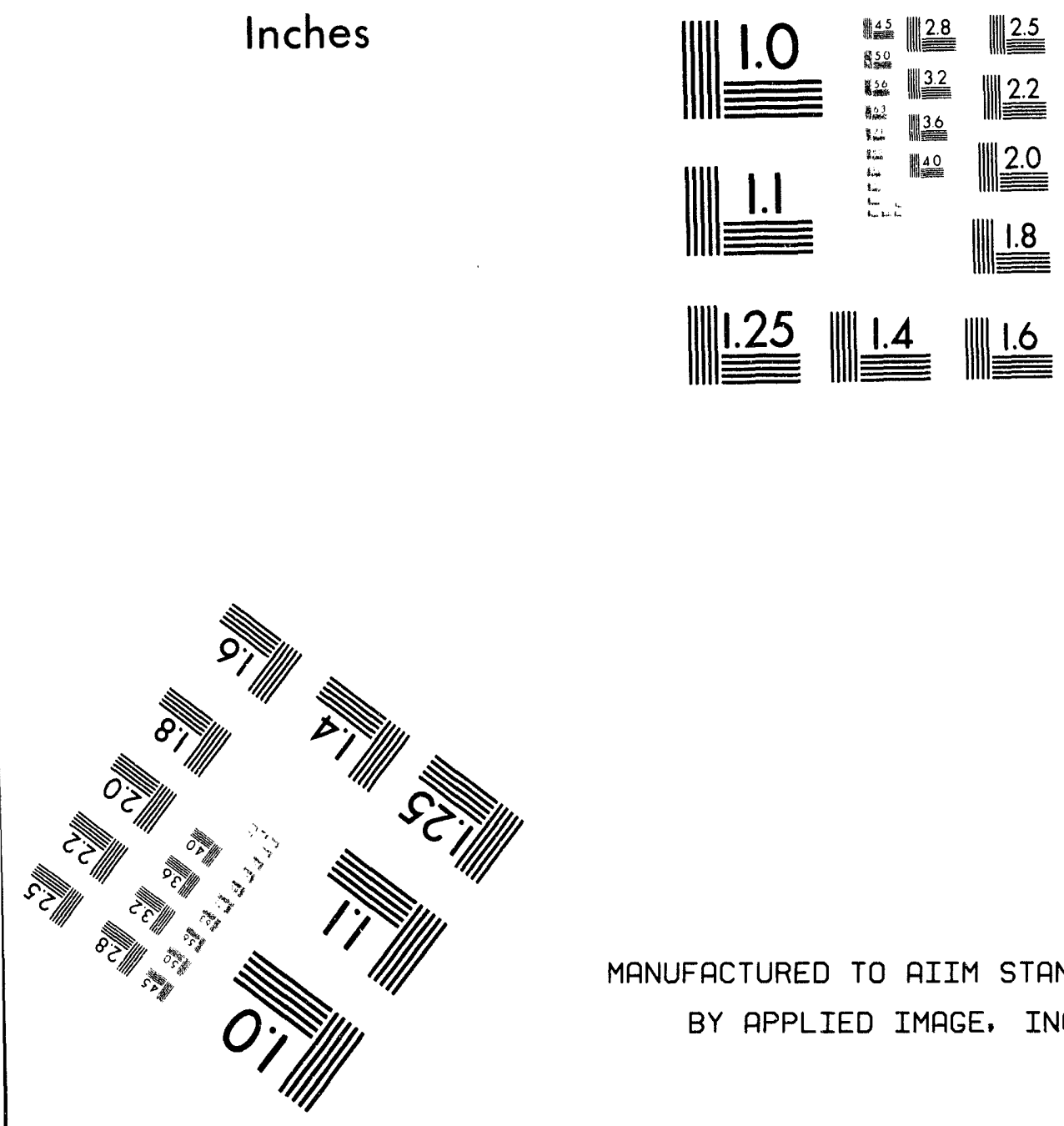

MANUFACTURED TO AIIM STANDARDS

BY APPLIED IMAGE, INC.

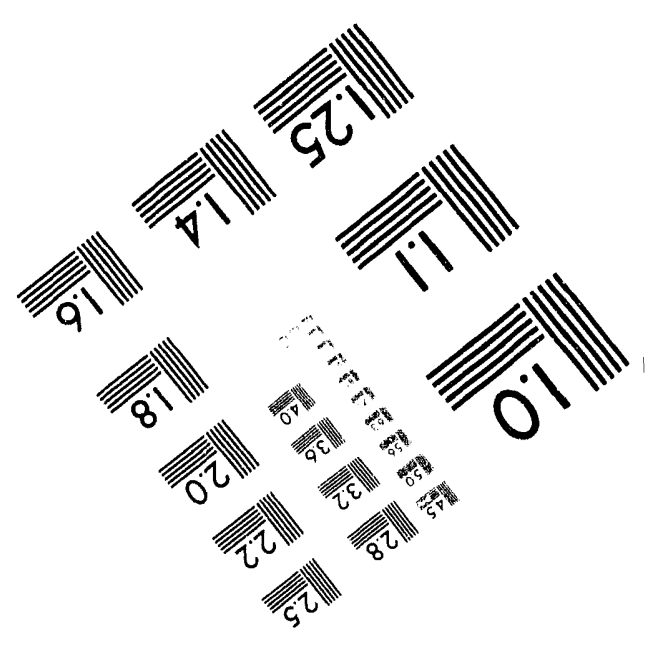



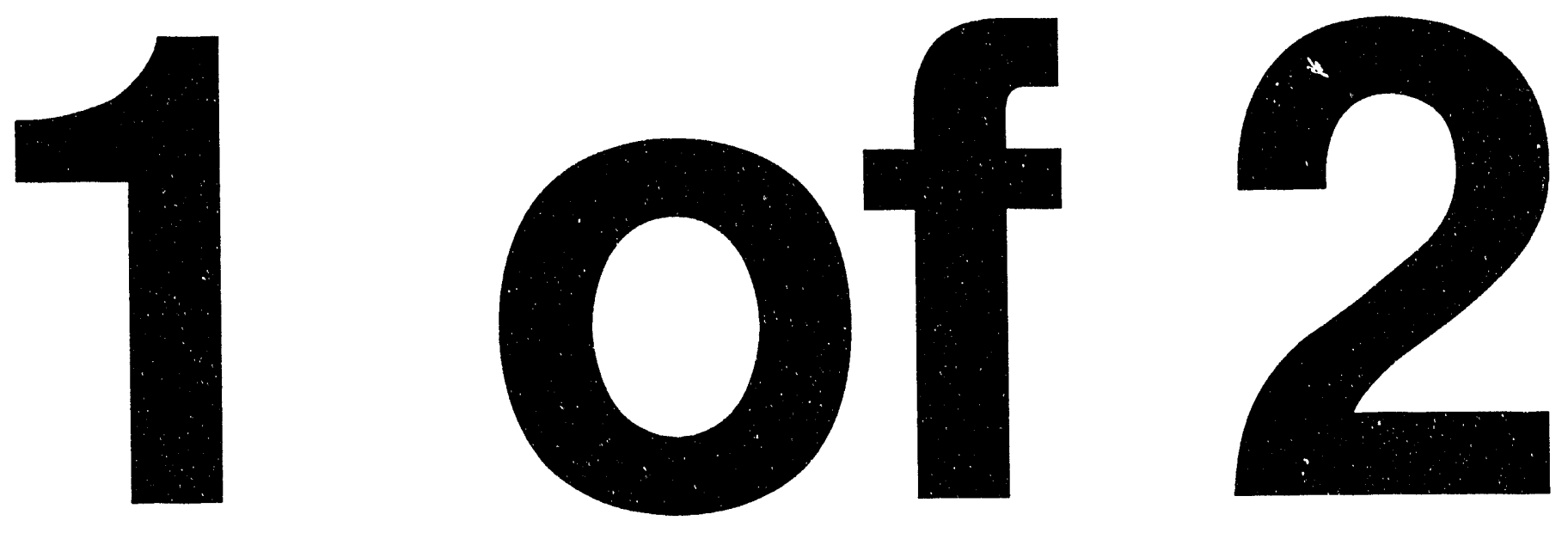


\section{FEASIBILITY STUDY FOR THE \\ UNITED HECKATHORN SUPERFUND SITE \\ RICHMOND, CALIFORNIA}
A. H. Lincoff ${ }^{(a)}$
G. P. Costan
M. S. Montgomery
P. J. White

July 1994

Prepared for the

U. S. Environmental Protection Agency

under a Related Services Agreement

with the U.S. Department of Energy

Contact DE-AC06-76RL0 1830

Pacific Northwest Laboratory

Richland, Washington 99352

(a) U.S. Environmental Protection Agency

Region IX

San Francisco, California. 


\section{SUMMARY}

The United Heckathorn Superfund Site in Richmond, California, was used to formulate pesticides from approximately 1947 to 1966 . Soils at the site and sediments in the harbor were contaminated with various chlorinated pesticides, primarily DDT, as a result of these activities. The U.S. Environmental Protection Agency (EPA) listed the site on the Superfund National Priorities List (NPL) in 1990. This document is part of the Remedial Investigation and Feasibility Study (RI/FS) phase of the Superfund response, which will provide the basis for selection of a final remedy that will protect human health and the environment and achieve compliance with federal and state environmental laws.

Several response actions have already been taken to clean up the most contaminated areas of the site. At the time of site listing in 1990, a visible deposit of pesticide residue containing up to $100 \%$ DDT was present on the Lauritzen Channel embankment. . Under an EPA removal order, a group of Potentially Responsible Parties (PRPs) excavated this deposit and transported it offsite to a permitted disposal facility. During subsequent actions through 1993, all known additional soil deposits containing high levels of pesticides were removed, as were piles of contaminated soils generated in earlier actions.

The RI of the site included soil, sediment, air and groundwater sampling that characterized site conditions and the nature and extent of contamination. Most of the investigation of upland areas was performed under state orders prior to NPL listing. EPA's investigations focused on completing the site characterization with human health and ecological risk assessments, offsite soil screening, and extensive marine sediment characterization.

The results of the human health and ecological risk assessments indicate that the upland conditions at the site do not pose a threat to surrounding communities, and that the upland and embankment soil removal actions reduced the concentrations of contaminants of concern in soils to acceptable levels for current and expected future industrial uses. The remaining unacceptable site risks are confined to marine exposure pathways.

DDT concentrations at the northern end of the Lauritzen Channel are six orders of magnitude greater than the concentrations at the mouth of Richmond Harbor. Lauritzen Channel sediments are acutely toxic to sensitive marine organisms. DDT and dieldrin bioaccumulate in channel organisms to the highest levels found in the California State Mussel Watch Program. Fish-eating birds, including 
endangered brown pelicans, have been observed feeding in the most contaminated areas of the site, and DDT levels in fish exceed acceptable levels for consumption by birds by two orders of magnitude. DDT and dieldrin levels in fish in the Lauritzen Channel are also unacceptable for human consumption. Finally, the DDT and dieldrin concentrations in Lauritzen Channel surface water violate EPA ambient water quality criteria and state water quality objectives and, because of transport, also cause violations in the Santa Fe Channel.

The purpose of this FS is to develop remedial alternatives that address the remaining unacceptable site risks. This is accomplished by identifying remedial action objectives; identifying potential technologies to meet the objectives; screening the technologies based on effectiveness, implementability, and cost; and developing and analyzing remedial alternatives.

The primary remedial action objective identified for the site is the attainment of the EPA water quality criteria and the equivalent state objectives for bay waters, which are applicable, or relevant and appropriate requirements (ARARs) of federal and state environrnental laws. This objective is expected to be achieved by the remediation of contaminated sediment in the Lauritzen Channel and Parr Canal. Another remedial action objective is to prevent the erosion and transport of upland soils into the Lauritzen Channel.

The potential technologies identified for meeting the remedial objective included various methods of treatment, containment by capping or consolidation in confined disposal facilities, and removal and offsite disposal. Treatment and capping in-situ were determined not to be practicable, and the following four alternatives were developed for detailed analysis: 1) no action; 2) dredging with consolidation at the Port of Richmond's drydocks; 3) dredging with consolidation in a confined disposal facility in the Lauritzen Channel; and 4) dredging with offsite disposal by rail.

The no action alternative is presented for comparison with the other alternatives. Additional components of the three dredging alternatives include monitoring programs to demonstrate the longterm effectiveness of the remedy, paving of upland areas at the former Heckathorn location to prevent erosion and stormwater runoff to the marine environment, and a deed restriction or notice limiting future site uses to the current commercial or port classification without further study. Prior to dredging, silt curtains would be erected to seal off the excavation areas from the rest of the harbor in order to minimize short-term environmental impacts. The four alternatives were then analyzed in detail using the evaluation criteria established in the National Oil and Hazardous Substance 
Contingency Plan. The no action alternative would not protect human health or the environment, or achieve compliance with ARARs, and so is not eligible for selection as the proposed action.

Consolidation of contaminated sediments at the Port of Richmond's drydocks would be expected to provide long-term protection of human health and the environment, and achieve compliance with ARARs. The facility would require a partnership between the parties performing the remedy and the City of Richmond to accomplish the dual purpose of waste containment and upgrading the obsolete port facility to provide additional shipping capacity. The facility could be constructed at a reasonable cost; however, this alternative might be difficult to implement because of long-term maintenance and liability concerns. The concentration of wastes in the shoreline facility would exceed state hazardous waste levels, and perpetual maintenance would be required. Agreements among numerous parties would have to be reached to assign liabilities associated with the proposed facility. Assuming agreements could be reached, the remediation action could be accomplished in 6 to 12 months, although it would take about four years for the sediments to consolidate sufficiently for capping and use. The estimated total cost of this alternative is $\$ 5.6$ million, assuming that the City of Richmond would not require additional compensation or purchase of the facility itself. This estimate also assumes that no additional environmental mitigation would be required for the bay fill associated with the facility. If mitigation were required, it could significantly increase the cost of this alternative.

Consolidation of contaminated sediments in a confined disposal facility in the Lauritzen Channel would also be expected to provide long-term protection of human health and the environment, and achieve compliance with the water quality ARARs. The concentration of wastes in the shoreline facility would exceed state hazardous waste levels, and perpetual maintenance would be required. It is likely, however, that the project would not comply with laws regulating bay fill unless it were determined that it were necessary to protect the environment and no practicable alternatives were available. A confined disposal facility could be constructed at a reasonable cost. However, if the configuration chosen negatively affected other properties, agreements would have to be reached regarding loss of shoreline and access. This remedial action could be accomplished in approximately one year, although it would take several years for the sediments in the facility to consolidate. The estimated cost for this alternative is $\$ 4.3$ to $\$ 13$ million, depending on the configuration chosen. 
These estimates assume that no additional environmental mitigation would be required for the bay fill associated with the facilities. If additional mitigation were required, it could significantly increase costs.

Finally, dredging with offsite disposal would also be expected to provide long-term protection of human health and the environment, and to achieve compliance with the water quality ARARs. This alternative would require no bay fill and would not require perpetual maintenance of a shoreline disposal facility. Rail transportation is available at the Lauritzen Channel shoreline, and watertight rail cars would be used to ensure that there would be no releases between the site and the disposal facility. This remedial action could be accomplished in approximately two months, at an estimated cost of $\$ 6.8$ million.

EPA will use this use this FS to prepare a Proposed Plan for public comment, which will recommend one of the above remedial alternatives for the site. After considering state and community acceptance, EPA will issue a Record of Decision containing the final remedy selection. 


\section{CONTENTS}

SUMMARY $\ldots \ldots \ldots \ldots \ldots \ldots \ldots \ldots \ldots \ldots \ldots \ldots \ldots \ldots \ldots \ldots \ldots$

LIST OF ACRONYMS $\ldots \ldots \ldots \ldots \ldots \ldots \ldots \ldots \ldots \ldots \ldots \ldots \ldots \ldots$

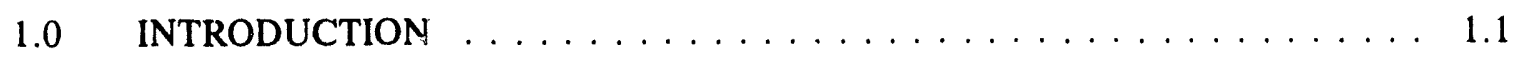

1.1 PURPOSE AND SCOPE $\ldots \ldots \ldots \ldots \ldots \ldots \ldots \ldots \ldots \ldots$

1.2 ORGANIZATION $\ldots \ldots \ldots \ldots \ldots \ldots \ldots \ldots \ldots \ldots \ldots$

1.3 SITE DESCRIPTION $\ldots \ldots \ldots \ldots \ldots \ldots \ldots \ldots \ldots$

1.3.1 Upland and Embankment Areas . . . . . . . . . . . 1.5

1.3.2 Marine Areas . . . . . . . . . . . . . . . . . 1.5

1.4 SITE HISTORY $\ldots \ldots \ldots \ldots \ldots \ldots \ldots \ldots$

1.4 .1 Site Use Activities . . . . . . . . . . . . . 1.10

1.4 .2 Previous Investigations $\ldots \ldots \ldots \ldots \ldots \ldots \ldots \ldots \ldots \ldots$

1.4 .3 Site Remediation Activities $\ldots \ldots \ldots \ldots \ldots \ldots$

1.5 NATURE AND EXTENT OF CONTAMINATION $\ldots \ldots \ldots \ldots$

1.5.1 Distribution of Chemicals in the Upland Area $\ldots \ldots \ldots \ldots 1.14$

1.5.2 Distribution of Chemicals in Marine Sediment $\ldots \ldots \ldots \ldots 1.16$

1.6 CONTAMINANT FATE AND TRANSPORT $\ldots \ldots \ldots \ldots \ldots \ldots$

1.6.1 Fate and Transport of Pesticides in the Upland Area $\ldots \ldots \ldots 1.23$

1.6.2 Marine Sediment Fate and Transport . . . . . . . . . 1.25

1.7 BASELINE RISK ASSESSMENT $\ldots \ldots \ldots \ldots \ldots \ldots \ldots$

1.7.1 Human Health Risk Assessment . . . . . . . . . . . . . . 1.27

1.7 .2 Ecological Assessment . . . . . . . . . . . . . . . . . . . . 1.29

1.8 TREATABILITY TESTING $\ldots \ldots \ldots \ldots \ldots \ldots \ldots \ldots \ldots$

1.9 REMEDIAL INVESTIGATION SUMMARY $\ldots \ldots \ldots \ldots \ldots \ldots \ldots$ 


\section{CONTENTS (contd)}

2.0 REMEDIAL ACTION OBJECTIVES $\ldots \ldots \ldots \ldots \ldots \ldots \ldots \ldots$

2.1 APPLICABLE OR RELEVANT AND APPROPRIATE

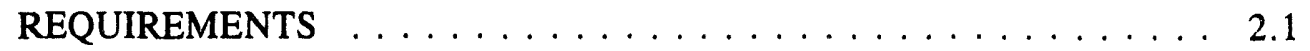

2.1.1 Chemical-Specific Requirements . . . . . . . . . . . 2.2

2.1.2 Location-Specific Requirements . . . . . . . . . . 2.10

2.1.3 Action-Specific Requirements . . . . . . . . . . . . . . . 2.12

2.2 REMEDIAL ACTION GOALS $\ldots \ldots \ldots \ldots \ldots \ldots \ldots$

2.2 .1 Marine Area $\ldots \ldots \ldots \ldots \ldots \ldots \ldots \ldots . \ldots \ldots$

2.2.2 Upland/Embankment Areas . . . . . . . . . . . . . 2.15

2.3 VOLUME OF MARINE SEDIMENT REQUIRING REMEDIATION . . . 2.15

3.0 IDENTIFICATION AND SCREENING OF TECHNOLOGIES $\ldots \ldots \ldots \ldots \ldots .1$

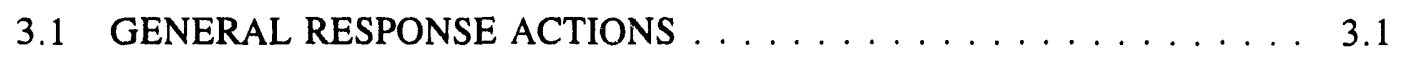

3.1 .1 Institutional Controls $\ldots \ldots \ldots \ldots \ldots \ldots \ldots \ldots \ldots \ldots$

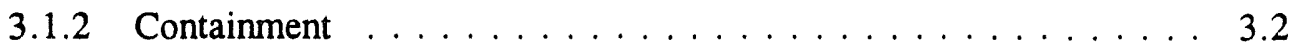

3.1 .3 Removal . . . . . . . . . . . . . . . 3.2

3.1 .4 Treatment $\ldots \ldots \ldots \ldots \ldots \ldots \ldots \ldots \ldots \ldots \ldots \ldots$

3.1 .5 Disposal . . . . . . . . . . . . . . . 3.3

3.2 SCREENING CRITERIA $\ldots \ldots \ldots \ldots \ldots \ldots \ldots \ldots \ldots \ldots$

3.2 .1 Effectiveness $\ldots \ldots \ldots \ldots \ldots \ldots \ldots \ldots \ldots \ldots$

3.2 .2 Implementability $\ldots \ldots \ldots \ldots \ldots \ldots \ldots \ldots$

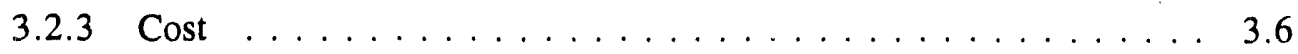

3.3 SCREENING OF REMEDIAL TECHNOLOGIES AND

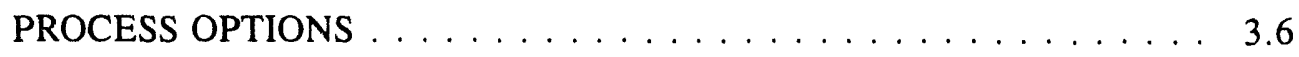

3.3 .1 Institutional Controls $\ldots \ldots \ldots \ldots \ldots \ldots \ldots$

viii 
CONTENTS (contd)

3.3.2 Containment $\ldots \ldots \ldots \ldots \ldots \ldots \ldots \ldots \ldots \ldots$

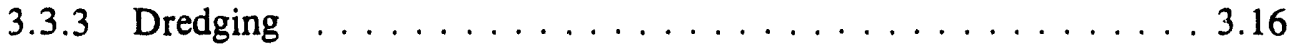

3.3.4 Treatment . . . . . . . . . . . . . . . . . . 3.19

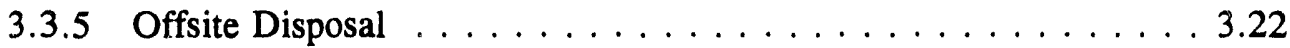

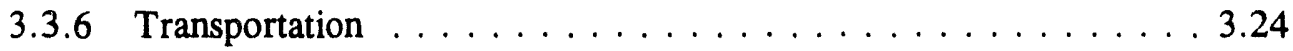

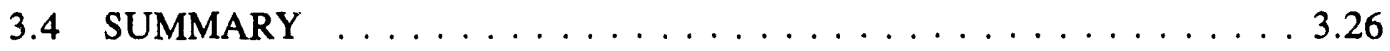

4.0 DETAILED EVALUATION OF REMEDIAL ALTERNATIVES . . . . . . . . 4.1

4.1 EVALUATION CRITERIA $\ldots \ldots \ldots \ldots \ldots \ldots \ldots \ldots \ldots$

4.1.1 Overall Protection of Human Health and the Environment . . . . 4.2

4.1 .2 Compliance with ARARs $\ldots \ldots \ldots \ldots . \ldots \ldots . \ldots \ldots$

4.1.3 Long-Term Effectiveness and Permanence . . . . . . . . . . 4.3

4.1.4 Reduction of Toxicity, Mobility, or Volume through Treatment . . 4.3

4.1.5 Short-Term Effectiveness $\ldots \ldots \ldots \ldots \ldots \ldots$

4.1 .6 Implementability $\ldots \ldots \ldots \ldots \ldots \ldots \ldots \ldots$

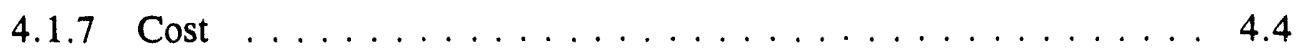

4.2 COMMON ELEMENTS $\ldots \ldots \ldots \ldots \ldots \ldots \ldots \ldots \ldots$

4.2.1 Dredging $\ldots \ldots \ldots \ldots \ldots \ldots \ldots \ldots \ldots \ldots \ldots \ldots \ldots$

4.2 .2 Monitoring $\ldots \ldots \ldots \ldots \ldots \ldots \ldots \ldots \ldots \ldots \ldots \ldots$

4.2 .3 Paving of Upland Area $\ldots \ldots \ldots \ldots \ldots \ldots \ldots$

4.2 .4 Institutional Controls $\ldots \ldots \ldots \ldots \ldots \ldots \ldots$

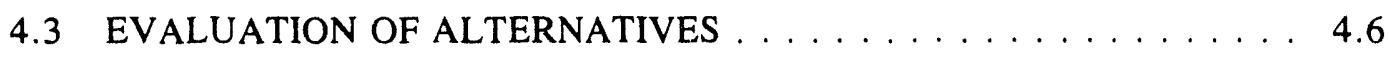

4.3.1 Alternative 1: No Action with Monitoring $\ldots \ldots \ldots . . \ldots$ 


\section{CONTENTS (contd)}

4.3.2 Alternative 2: Dredging with Containment at the Point

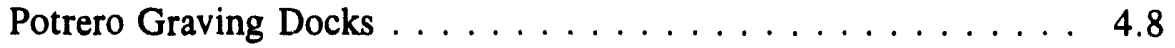

4.3.3 Alternative 3: Dredging with Containment at Lauritzen Canal . . . . . . . . . . . . . . . . . . . 4.15

4.3.4 Alternative 4: Dredging with Offsite Disposal . . . . . . 4.25 4.4 COMPARATIVE ANALYSIS OF REMEDIAL ALTERNATIVES . . . . 4.27

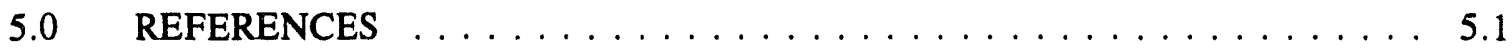
APPENDIX: COST ESTIMATES $\ldots \ldots \ldots \ldots \ldots \ldots \ldots \ldots \ldots$ A.1 


\section{FIGURES}

1.1 Site Location Map $\ldots \ldots \ldots \ldots \ldots \ldots \ldots \ldots \ldots \ldots \ldots$

1.2 Map of Richmond Harbor $\ldots \ldots \ldots \ldots \ldots \ldots \ldots \ldots \ldots \ldots$

$1.3 \quad$ Map of the Lauritzen Channel $\ldots \ldots \ldots \ldots \ldots \ldots \ldots \ldots \ldots$

1.4 Shoreline Features in Richmond Harbor $\ldots \ldots \ldots \ldots \ldots \ldots \ldots \ldots$

1.5 Upland Soils with Pesticide Concentrations Exceeding $1 \mathrm{ppm} \ldots \ldots \ldots \ldots 1.15$

1.6 Average Total DDT in Younger Bay Mud, Inner Richmond Harbor $\ldots \ldots \ldots$

2.1 Elevation of the Mudline and Older Bay Mud Contact in the Lauritzen Channel . 2.16

2.2 Cross-Sections of the Lauritzen Channel Showing Total DDT Concentrations . 2.17

$2 .{ }^{2} \quad$ Cross-Section Locations $\ldots \ldots \ldots \ldots \ldots \ldots \ldots \ldots \ldots \ldots \ldots \ldots$

3.1 Proposed Location of Confined Disposal Facility at the Parr Canal . . . . . . . 3.13

3.2 Cross-Section of Proposed Confined Disposal Facility at the Parr Canal . . . . . 3.14

$4.1 \quad$ Limit of Proposed Asphalt Cap for Upland Soils $\ldots \ldots \ldots \ldots \ldots$. . . . . . 4.7

4.2 Configuration of Graving Docks Under Alternative $2 \ldots \ldots \ldots \ldots$

4.3 Cross-Section of Graving Docks Under Alternative $2 \ldots \ldots \ldots \ldots \ldots .11$

4.4 Configuration of Sheetpile Wall, Alternative $3 \ldots \ldots \ldots \ldots \ldots .17$

4.5 Cross-Section of the East Bank of the Lauritzen Channel, Alternative $3 \ldots \ldots$. . . 48

4.6 Cross-Section of Proposed Anchored Bulkhead Along Wharf, Alternative 3 . . . 4.19

4.7 Configuration of Rock Dam, Alternative $3 \ldots \ldots \ldots \ldots \ldots$

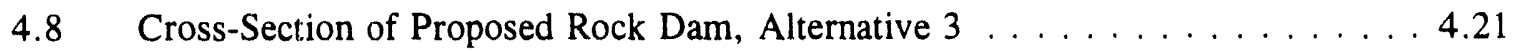

\section{TABLES}

$1.1 \quad$ Remedial Investigation Reports $\ldots \ldots \ldots \ldots \ldots \ldots \ldots \ldots$

1.2 Mean Upland Soil Concentrations for Potential Contaminants of Concern . . . . 1.16 


\section{TABLES (contd)}

1.3 Estimated Volume of Younger Bay Mud and Average DDT Concentration . . . 1.22

1.4 Physical and Chemical Properties of DDT and Dieldrin $\ldots \ldots \ldots \ldots \ldots$

$2.1 \quad$ EPA Ambient Water Quality Criteria $\ldots \ldots \ldots \ldots \ldots \ldots$

2.2 State of California Hazardous Waste Limits $\ldots \ldots \ldots \ldots \ldots$

2.3 National Academy of Sciences Saltwater Action Levels $\ldots \ldots \ldots \ldots$

2.4 Food and Drug Administration Action Levels $\ldots \ldots \ldots \ldots \ldots$

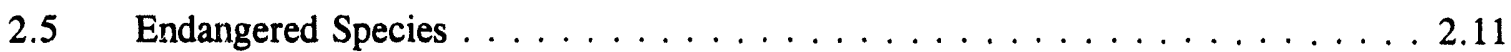

$2.6 \quad$ Remedial Action Goals $\ldots \ldots \ldots \ldots \ldots \ldots \ldots \ldots \ldots$

3.1 Characteristics of Younger Bay Mud in the Lauritzen Channel and Parr Canal . . 3.5

3.2 Initial Screening of Process Options for Marine Sediment . . . . . . . . . 3.27

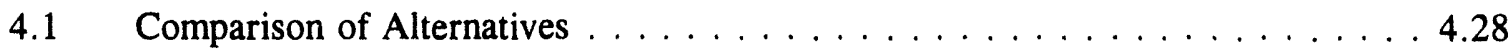




\section{LIST OF ACRONYMS}

\begin{tabular}{|c|c|}
\hline ARAR & Applicable or Relevant and Appropriate Requirement \\
\hline $\mathrm{BCDC}$ & Bay Conservation and Development Commission \\
\hline CDF & Confined Disposal Facility \\
\hline CDFG & California Department of Fish and Game \\
\hline CDHS & California Department of Health Services \\
\hline CERCLA & Comprehensive Environmental Response, Compensation, and Liability Act \\
\hline CFR & Code of Federal Regulations \\
\hline $\mathrm{COC}$ & Contaminant of Concern \\
\hline CZMA & Coastal Zone Management Act \\
\hline DDT & Dichlorodiphenyltrichloroethane \\
\hline DTSC & California Department of Toxic Substances Control \\
\hline EPA & U.S. Environmental Protection Agency \\
\hline FDA & Food and Drug Administration \\
\hline FS & Feasibility Study \\
\hline FWS & U.S. Fish and Wildlife Service \\
\hline GAC & Granular Activated Carbon \\
\hline $\mathrm{HI}$ & Hazard Index \\
\hline HLA & Harding Lawson Associates \\
\hline HWCL & Hazardous Waste Control Law \\
\hline IRIS & Integrated Risk Information System \\
\hline LRTC & Levin Richmond Terminal Corporation \\
\hline LTMS & Long Term Management Strategy \\
\hline MSL & Battelle/Marine Sciences Laboratory \\
\hline
\end{tabular}




\begin{tabular}{|c|c|}
\hline NAS & National Academy of Sciences \\
\hline NCP & National Oil and Hazardous Substance Contingency Plan \\
\hline NOAA & National Oceanographic and Atmospheric Administration \\
\hline NPL & National Priorities List \\
\hline PAH & Polynuclear Aromatic Hydrocarbon \\
\hline PCB & Polychlorinated Biphenyl \\
\hline PRP & Potentially Responsible Party \\
\hline RCRA & Resource Conservation and Recovery Act \\
\hline RI & Remedial Investigation \\
\hline RME & Reasonable Maximum Estimates \\
\hline ROD & Record of Decision \\
\hline SARA & Superfund Amendments and Reauthorization Act \\
\hline SFRWQCB & San Francisco Regional Water Quality Control Board \\
\hline SPP & Suspended Particulate Phase \\
\hline STLC & Soluble Threshold Limit Concentration \\
\hline TBC & To Be Considered \\
\hline TTLC & Total Threshold Limit Concentration \\
\hline USACE & U.S. Army Corps of Engineers \\
\hline WET & Waste Extraction Test \\
\hline
\end{tabular}




\subsection{INTRODUCTIRN}

The United Heckathorn Superfund Site is located in Richmond, California (Figure 1.1). The site was used by several operators, including United Heckathorn, to process and package pesticides, primarily dichlorodiphenyltrichloroethane (DDT), from the 1940s to the 1960s. These activities resulted in the contamination of upland soils and marine sediment in the adjacent waterways. The site was placed on the National Priorities List (NPL) in 1990. This document is part of the Remedi.3l Investigation and Feasibility Study (RI/FS) phase of the Superfund response process, which will provide the basis for selection of a final remedy that will protect human health and the environment and achieve compliance with federal and state environmental laws.

Several response actions have already been taken to clean up the most contaminated areas of the site. At the time of site listing in 1990, a visible deposit of pesticide residue containing up to $100 \%$ DDT was present on the Lauritzen Channel embankment. Under a U.S. Environmental Protection Agency (EPA) emergency removal order, a group of Potentially Responsible Parties (PRPs) excavated this deposit and transported it offsite to a permitted disposal facility. During subsequent actions through 1993, all known additional soil deposits containing high levels of pesticides were removed, as were piles of contaminated soils generated in earlier actions.

The RI of the site began in 1985 and consists of studies of soil, sediment, biota, air, and groundwater. Most of the upland area investigations were performed under state orders prior to the NPL listing. EPA's investigations, conducted since 1990, have focused on completing the site characterization and include offsite soil screening, extensive marine sediment sampling, and human health and ecological risk assessments. All documents containing RI sampling results are listed in Table 1.1. EPA's human health risk assessment (ICF Technology 1994), ecological assessment (EPA 1994), and marine RI (White et al. 1994) summarize current site conditions for all media. The human health and ecological risk assessments indicate that the upland conditions at the site do not pose a threat to surrounding communities and that the upland and embankment soil removal actions have reduced the concentrations of contaminants of concern (COCs) in soils to acceptable levels for current and expected future industrial uses. The unacceptable risks which currently exist at the site are confined to marine exposure pathways. 


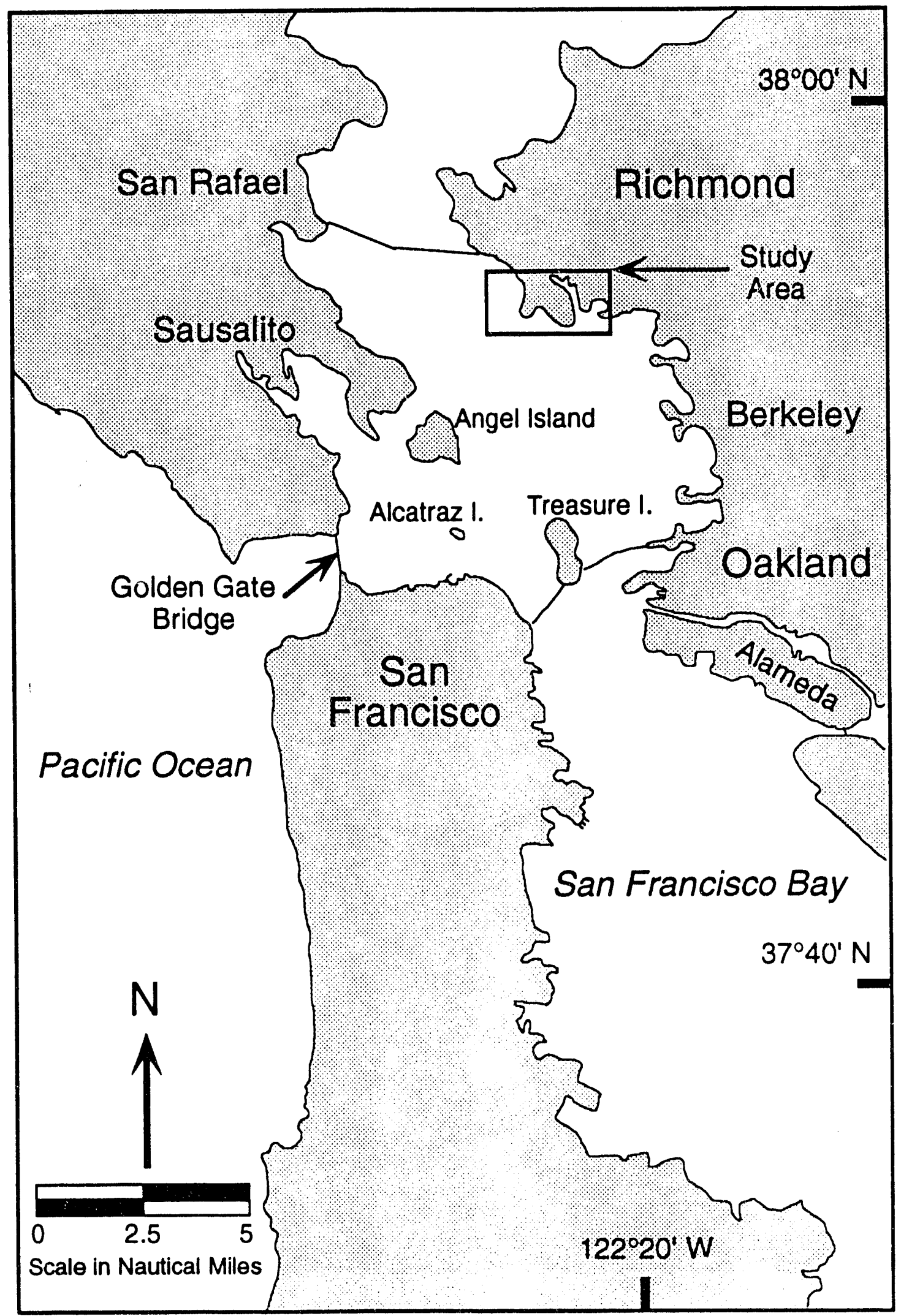

FIGURE 1.1. Site Location Map 
TABLE 1.1. Remedial Investigation Reports

\begin{tabular}{|c|c|c|}
\hline Date & Author & Title \\
\hline 06-Nov-86 & HLA & $\begin{array}{l}\text { Revised Draft Site Characterization and Remedial } \\
\text { Action Plan, Former United Heckathorn Site, } \\
\text { Richmond, California }\end{array}$ \\
\hline 17-May-90 & Levine-Fricke & $\begin{array}{l}\text { Remedial Investigation, United Heckathorn Site, } \\
\text { Richmond, California }\end{array}$ \\
\hline 11-Jan-91 & Levine-Fricke & $\begin{array}{l}\text { Interim Remedial Actions Performed Along the } \\
\text { Embankment, United Heckathorn Site, Richmond, } \\
\text { California }\end{array}$ \\
\hline 31-May-91 & Levine-Fricke & $\begin{array}{l}\text { Removal of Pesticide-Affected Soil, United } \\
\text { Heckathorn Site, Richmond, California }\end{array}$ \\
\hline 03-Feb-93 & Levine-Fricke & $\begin{array}{l}\text { "Hot-Spot" Soil Investigation Report, United } \\
\text { Heckathorn Site, Richmond, California }\end{array}$ \\
\hline May-94 & EPA & $\begin{array}{l}\text { Ecological Risk Assessment of the Marine Sediments } \\
\text { at the United Heckathorn Site }\end{array}$ \\
\hline 08-July-93 & Levine-Fricke & $\begin{array}{l}\text { Removal of Hot-Spot Soils From the United } \\
\text { Heckathorn Site, Richmond, California }\end{array}$ \\
\hline 09-July-93 & Weston & Final Report for the United Heckathorn Site \\
\hline May-?4 & ICF Technology & $\begin{array}{l}\text { Human Health Risk Assessment for the United } \\
\text { Heckathorn Superfund Site, Richmond, California }\end{array}$ \\
\hline Feb-94 & White et al. & $\begin{array}{l}\text { Remedial Investigation of Marine Sediment at the } \\
\text { United Heckathorn Superfund Site }\end{array}$ \\
\hline
\end{tabular}

\section{$1.1 \quad$ PURPOSE AND SCOPE}

The sbjective of this FS is to identify and provide a detailed analysis of a range of alternatives for site remediation. This is accomplished using the following steps:

- formulation of remedial action objectives for the site based on protection of human health and the environment and applicable or relevant and appropriate requirements (ARARs) of federal and state law

- identification of areas of the site or volumes of contaminated media requiring remediation in order to achieve the remedial action objectives

- identification, development, screening, and evaluation of a range of alternatives capable of achieving the remedial action objectives. 
- identification, development, screening, and evaluation of a range of alternatives capable of achieving the remedial action objectives.

The results of this FS will be used by the EPA in consultation with the state of California to propose preferred remedial actions for the United Heckathorn site. The preferred alternative will be presented in a Proposed Plan for Remedial Action. After the Proposed Plan is reviewed by the public, EPA plans to respond to public comments and select a remedy in a Record of Decision (ROD).

This FS was conducted in accordance with the Comprehensive Environmental Response, Compensation, and Liability Act of 1980 (CERCLA), as amended by the Superfund Amendments and Reauthorization Act of 1986 (SARA). Implementation of the CERCLA remediation process is outlined in Title 40 of the Code of Federal Regulations (40 CFR) Part 300, National Oil and Hazardous Substance Contingency Plan (NCP). The process used to evaluate remedial alternatives is consistent with the Guidance for Conducting Remedial Investigations and Feasibility Studies Under CERCLA (EPA 1988).

\subsection{ORGANIZATION}

Section 1.0 of this report presents background information about the United Heckathorn site, consisting of a site description, site history, summary of previous investigations, discussion of the nature and extent of contamination and contaminant fate and transport, and a summary of the human health and ecological risk assessments of the site.

In Section 2.0, ARARs, remedial action objectives, and the areas exceeding remediation goals are defined. Section 3.0 identifies and describes possible general response actions and associated remedial technologies that could be applied at the United Heckathorn site. The response actions and technologies are screened on the basis of effectiveness, implementability, and cost.

Remedial alternatives based upon options that were retained through the screening process are presented and developed in Section 4.0. The remedial alternatives are evaluated in detail, using seven of the nine evaluation criteria specified in the NCP. The final two criteria, state and community acceptance, will be evaluated after comments are received on the proposed plan. The alternatives are also compared and contrasted to identify strengths and weaknesses. References are provided in Section 5.0, and breakdowns of the cost estimates for each alternative are provided in the appendix. 


\subsection{SITE DESCRIPTION}

The United Heckathorn site is located in Richmond Harbor, on the east side of San Francisco Bay (Figures 1.1 and 1.2). The location of the former United Heckathorn facility (Figure 1.3) is currently being used as a marine shipping terminal owned and operated by the Levin Richmond Terminal Corporation (LRTC). The area of contamination at the site includes the northern five acres of the terminal and marine sediments in harbor channels including the Lauritzen, which is immediately adjacent to the location of the former Heckathorn facility, the Santa Fe, the Parr Canal, and the Inner Harbor Channel.

\subsubsection{Upland and Embankment Areas}

The Richmond Harbor area was originally intertidal marshlands. Dredge and fill activities began prior to 1917 (CH2M Hill 1988), and no wetland or undisturbed areas remain within inner Richmond Harbor. The upland area is $7 \mathrm{ft}$ to $11 \mathrm{ft}$ above mean lower low water (MLLW) and is generally level. Upland soils consist of approximately $10 \mathrm{ft}$ of sandy, gravelly fill over the original intertidal bay mud and marsh. The bay muds are divided into two distinct geologic units: a softer layer referred to as "younger bay mud," which overlies a firmer, drier "older bay mud" (Goldman 1969). These units are described further in Section 1.3.2. The younger bay mud beneath the upland soils is roughly $20 \mathrm{ft}$ thick, and the underlying older bay mud in the Richmond shoreline area is approximately $50 \mathrm{ft}$ thick (Goldman 1969). Shallow groundwater occurs within some parts of the fill, particularly near the shoreline. The groundwater is saline and its elevation fluctuates with the tidal cycle. A freshwater aquifer may be present at depth underneath the bay mud (Goldman 1969).

The east bank of the Lauritzen Channel consists of a pile-supported pier over riprap and some vertical sheetpiling. The west bank is armored with riprap and has a small pier. The tidal zone ranges from approximately $-2 \mathrm{ft}$ to $+7 \mathrm{ft}$ MLLW. Shoreline features throughout the harbor are shown in Figure 1.4.

\subsubsection{Marine Areas}

The Lauritzen Channel and Parr Canal were originally natural channels in a saltwater marsh, which were widened and deepened by dredging as the adjacent land was filled. The Lauritzen Channel is approximately $1800 \mathrm{ft}$ long and varies in width from about $120 \mathrm{ft}$ at its north end to about $350 \mathrm{ft}$ at its south end. Its depth ranges from approximately $-10 \mathrm{ft}$ to $-40 \mathrm{ft}$ MLLW. Portions of the 


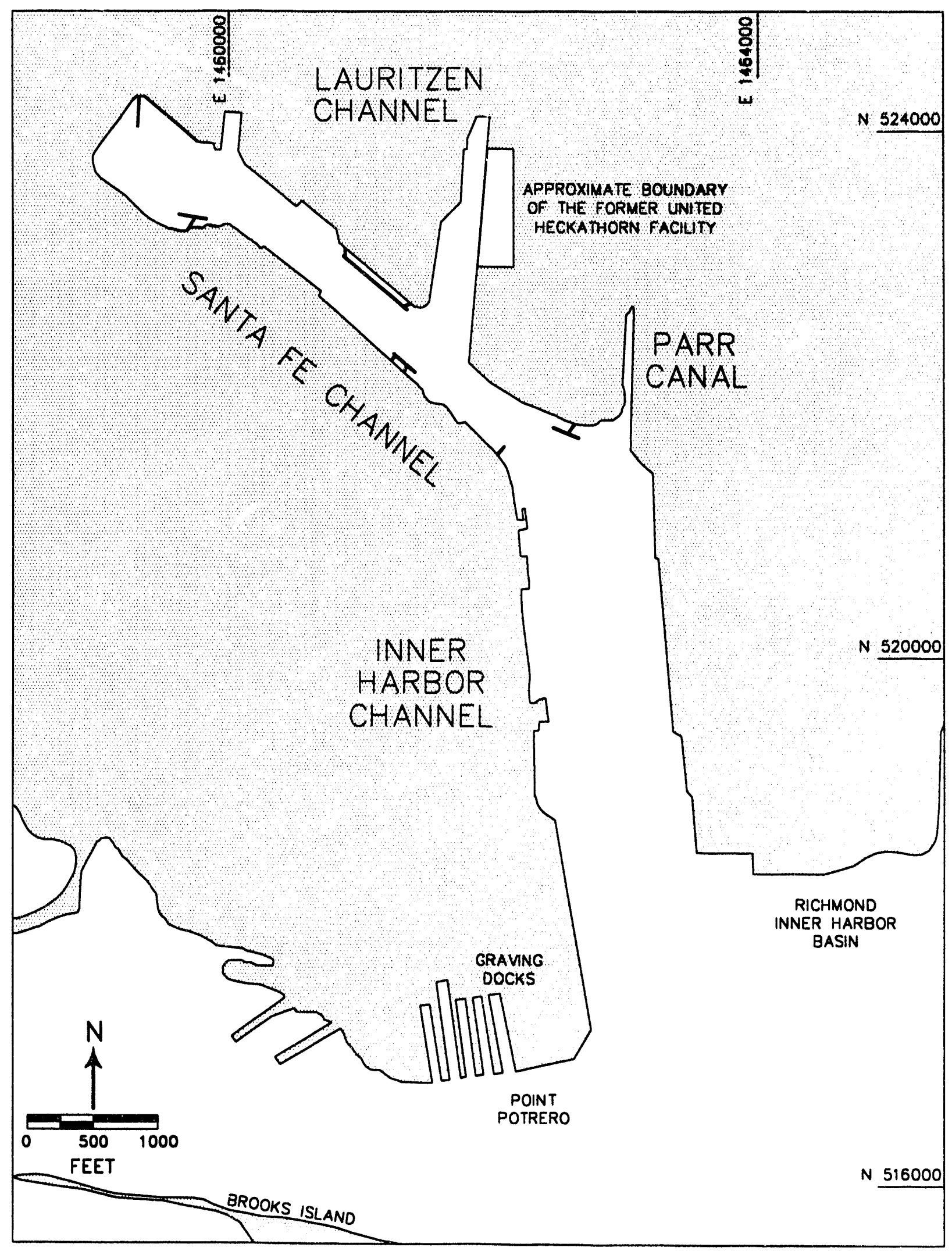

FIGURE 1.2. Map of Richmond Harbor 


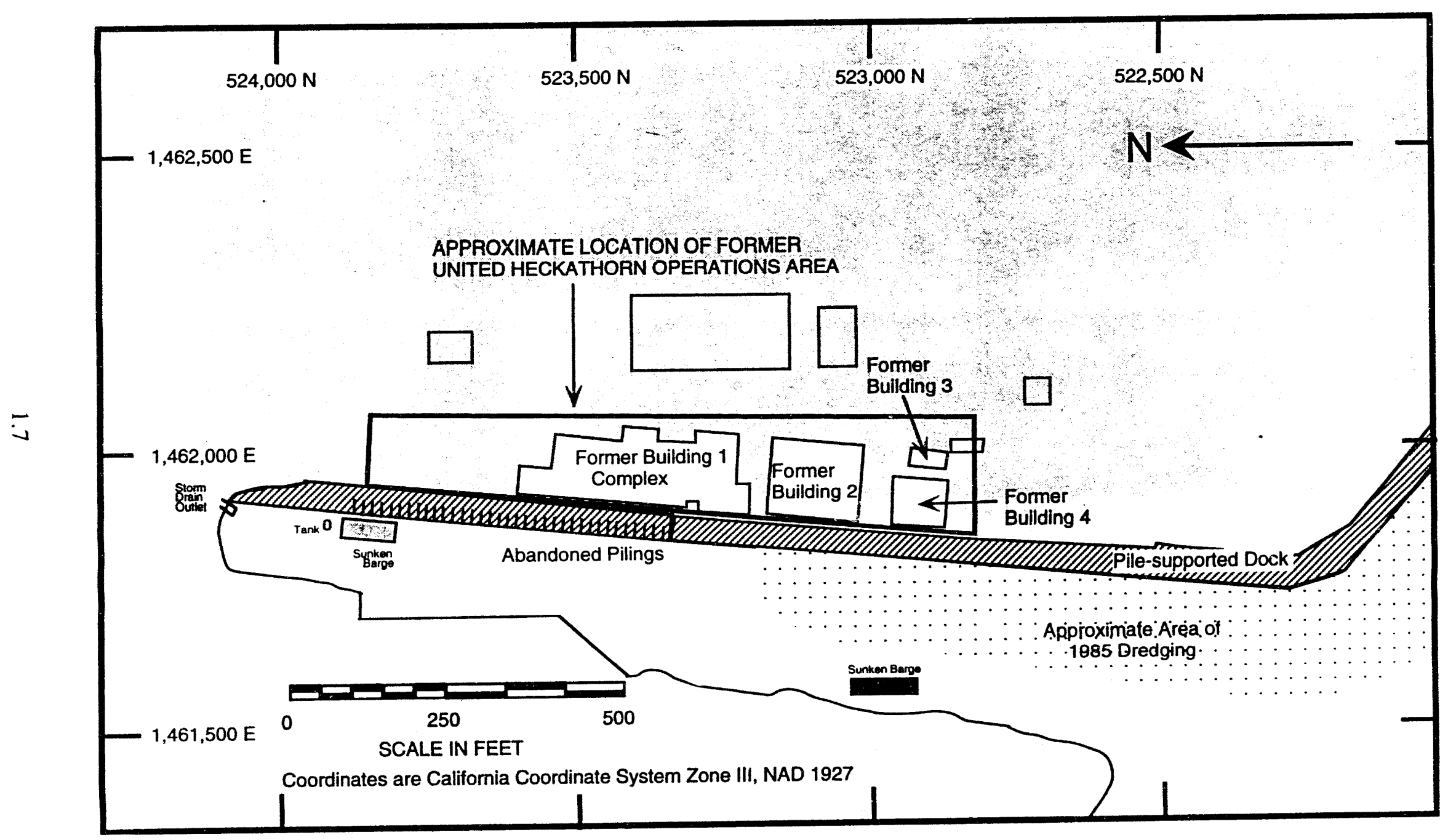

FIGURE 1.3. Map of the Lauritzen Channel 


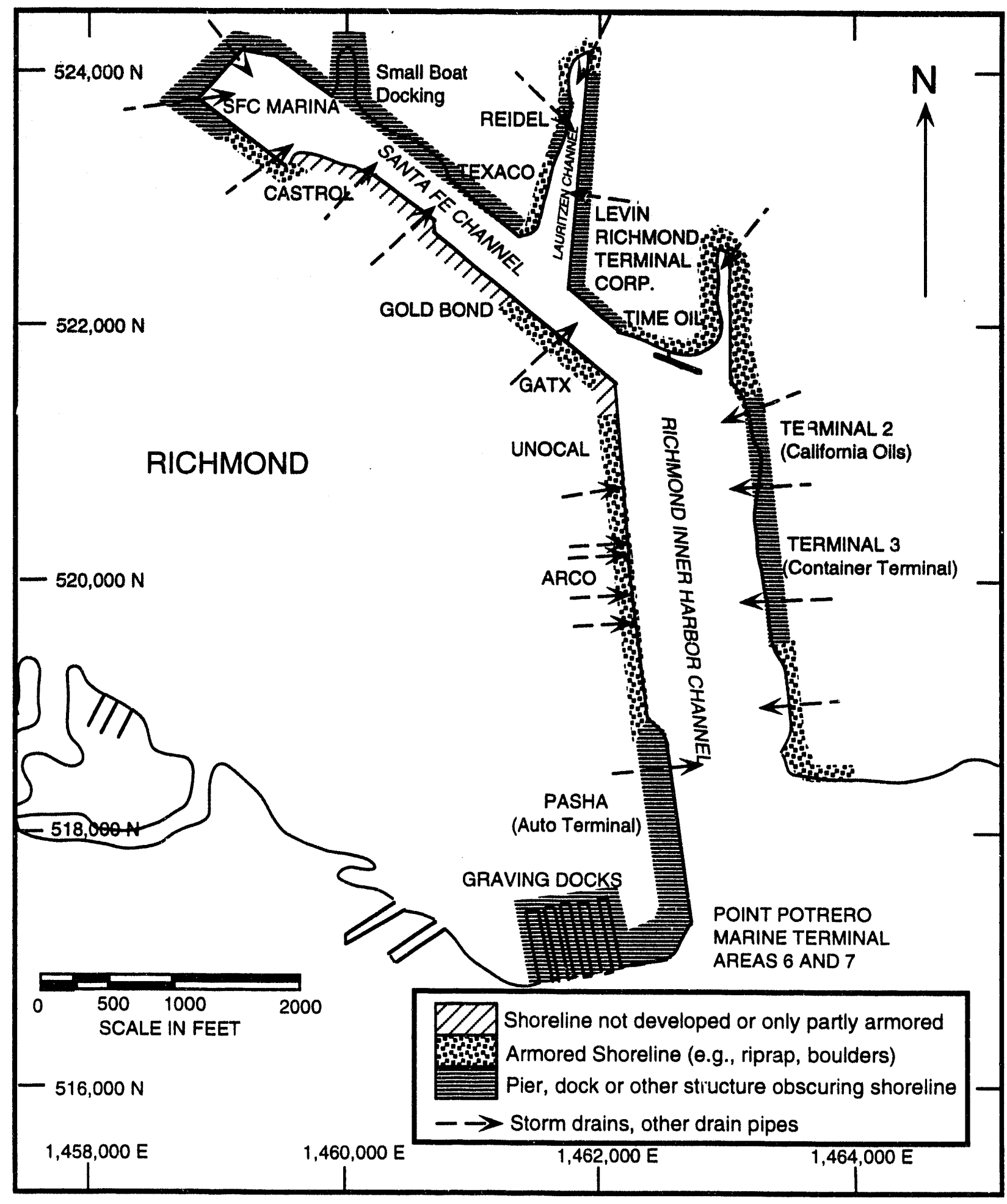

FIGURE 1.4. Shoreline Features in Richmond Harbor 
channel have been periodically dredged; the most recent maintenance dredging occurred in December 1984 and January 1985 and reached a depth of approximately $-41 \mathrm{ft}$ MLLW. It is not known when the northern and western portions of the channel were last dredged. Submerged debris in the northern part of the channel include a sunken barge and one metal tank, $5 \mathrm{ft}$ in diameter and $5 \mathrm{ft}$ high (Figure 1.3). Another sunken barge is located on the west side of the channel. A 5-ft diameter, reinforced concrete culvert enters the north end of the channel and provides stcrm drainage for the area north of the site.

The south end of the Lauritzen Channel enters the Santa Fe Channel (Figure 1.2). The Santa Fe Channel is approximately $4000 \mathrm{ft}$ long and $300 \mathrm{ft}$ wide. Approximately half of its length is maintained at a depth of $-35 \mathrm{ft}$ MLLW by the U.S. Army Corps of Engineers (USACE). The head of the channel and berth areas are maintained by the Port of Richmond or private owners; bathymetric maps provided by USACE indicate a depth of about $-32 \mathrm{ft}$ MLLW. The Santa Fe Channel connects at its east end with the Inner Harbor Channel, which flows into San Francisco Bay. The Inner Harbor Channel is maintained by USACE to a depth of -35 $\mathrm{ft}$ MLLW; a proposed deepening project will increase its depth to $-38 \mathrm{ft}$ MLLW. The Inner Harbor Channel terminates at Point Potrero. Five former drydocks, known as the graving docks, are located at Point Potrero.

The Parr Canal extends north from the north end of the Inner Harbor Channel. The Parr Canal is approximately $750 \mathrm{ft}$ long and $100 \mathrm{ft}$ wide. It is less than $10 \mathrm{ft}$ deep, and its shores are armored with riprap. A storm sewer discharges through a large culvert into the head of the canal. Aerial photographs indicate that it was much wider until at least 1958 and was filled to its present width prior to 1968 .

Marine sediment throughout inner Richmond Harbor consists of two geologic units: the younger bay mud and the underlying older bay mud (Goldman 1969). The ycunger bay mud is typically composed of black or dark gray, very soft to soft clay, silt, and fine-grained sand with a high water content. The silty clays are plastic and highly compressible. The younger bay mud has been forming in an estuarine environment since the last retreat of glacial ice (from about 15,000 to 18,000 years ago). The younger bay mud is up to $130 \mathrm{ft}$ thick in San Francisco Bay (Goldman 1969) and is generally less than $10 \mathrm{ft}$ thick in inner Richmond Harbor. The underlying older bay mud consists of relatively dry, firm to hard silts and clays with variable amounts of sand. The marine portions of the older bay mud are finer-grained and generally olive or gray in color. It is believed the older bay mud was deposited in shallow marine and terrestrial environments during the 
interglacial epoch immediately preceding the fornation of the Wisconsi: ice sheet and was exposed and subjected to erosion during the first Wisconsonian glacial advance (Goldman 1969). While exposed, the older bay mud sediments desiccated and consolidated. The older bay mud is up to $200 \mathrm{ft}$ thick, and appears to be approximately $50 \mathrm{ft}$ thick in the Richmond area. The older bay mud is suspected to be largely unaffected by anthropogenic contamination because of its pre-industrial age, low water content, and consolidated character. Engineering tests of older bay mud sediment collected near Point Potrero yielded a hydraulic conductivity value of $1 \times 10^{-4} \mathrm{~cm} / \mathrm{sec}$. The older bay muc in Richmond Harbor is underlain by interbedded sandstone and shale bedrock of the Franciscan Formation (Helley and Lojoie 1979).

\subsection{SITE HISTORY}

An operational history of the former United Heckathorn site is provided in a technical memorandum prepared for the California Department of Health Services (CDHS) (CH2M Hill 1988). Other reports provide additional information about site history and operations, hazardous materials used on the site, and spills and unauthorized releases (CH2M Hill 1987; Harding Lawson Associates [HLA] 1984, 1986a, 1986b; Levine-Fricke 1990).

\subsubsection{Site Use Activities}

The first industrial use of the United Heckathorn site is believed to have occurred in the early 1940s, when World War II shipbuilding operations were conducted in the area. Following the war, the shipyard and most of the supporting structures were demolished. The graving docks at Point Potrero remain from this era. Parr Richmond Terminal Company, Parr Terminal Company, and/or Parr Industrial Corporation owned and leased the site from the mid- to late-1940s until 1981. The site was used from approximately 1947 to 1966 by several operators, including the Parr Richmond Terminal Company, the Universal Pigment and Chemical Company, R.J. Prentiss Company, Heckathorn and Company, United Heckathorn, United Chemetrics, and Chemwest Incorporated to process and package various chemical products. Pesticides were shipped to United Heckathorn by their producers; no chemicals were manufactured onsite.

Documents from the 1950s and 1960s indicate that approximately $95 \%$ of Heckathorn's operations entailed processing the pesticide, DDT. The processing activities included mixing, blending, grinding, and packaging. Various solvents, including xylenes, were used to dissolve DDT and other pesticides into liquid formulations. Powder formulations were also prepared. 
United Heckathorn employees apparently routinely washed out equipment containing pesticide residues. The wash water was permitted to either run through drains that discharged to the Lauritzen Channel, or to seep into the ground adjacent to the site (Levine-Fricke 1990). Later, settling tanks were used to recover pesticide residues from wash water; however, overflow and leakage from these tanks occurred. In addition, accidental spills, leaks, and releases also occurred during the processing of liquid and dry pesticide formulations, which were conducted both inside and outside the United Heckathorn buildings.

In 1960, the San Francisco Regional Water Quality Control Board (SFRWQCB) inspected the facility and cited United Heckathorn for the release of DDT-laden wastewater into the Lauritzen Channel. In 1965, California Department of Fish and Game (CDFG) staff identified a discharge of wastewater overflow into the Lauritzen Channel and leakage from the pesticide settling tanks. ${ }^{a}$

Pesticide processing activities at the site ended in approximately 1966. Between 1966 and 1970, the United Heckathorn facility buildings were demolished and cleared from the site. In the 1970s, the site was apparently used primarily for bulk material storage. In 1981, Levin Metals Corporation purchased the property from Parr-Richmond Terminal Company and has been operating the site since that time as a bulk shipping facility.

In 1980, the United Heckathorn site was inspected and sampled by CDHS as part of the Abandoned Site Project. Chlorinated pesticides and metals were detected in soil samples, and the area was designated a state Superfund site in March 1982. EPA listed the United Heckathorn site on the NPL in March 1990, and took over as lead agency in August 1990.

\subsubsection{Previous Investigations}

Various environmental investigations have been conducted at the former United Heckathorn site since it was designated a state Superfund site in 1982. The chemical contamination of upland soils was characterized primarily by two studies performed under orders of the State of California, prior to the site's 1990 listing on the NPL (HLA 1986a; Levine-Fricke 1990). Additional sampling was performed during subsequent emergency removal actions conducted under EPA orders

a CDFG memorandum from Fred W. Kemp, January 18, 1965, "Pesticide pollution by Chemwest Co., 600 So. 4th St., Richmond." 
(Levine-Fricke 1990, 1991b, 1993; Weston 1993). Extensive marine sediment sampling was conducted by Battelle/Marine Sciences Laboratorya (MSL) for EPA in 1993 (White et. al 1994).

From 1983 to 1986, HLA conducted investigations for LRTC to define the nature and extent of contamination and to devise remedial action plans for the United Heckathorn site. These studies consisted of sampling and analysis of upland and embankment soil, groundwater, air, marine sediments, and marine organisms. HLA also modeled hydrogeologic conditions at the site. From 1989 to 1990 , Levine-Fricke completed investigations for LRTC to more fully assess the extent of contamination and to analyze remedial alternatives for the site. Results of these investigations are summarized in Section 1.5.1.

In 1990, a series of soil removal actions on the Levin Richmond Terminal began under EPA orders. By the end of 1993, all pesticide hot-spots were removed, and additional sampling further characterized remaining soil concentrations.

In the fall of 1991, EPA was unable to reach agreement with several PRPs; consequently, EPA assumed the lead for the preparation of the RI/FS for the site. ICF Technology Inc. began a human health risk assessment for EPA (ICF Technology 1994) and EPA began an ecological assessment (EPA 1994). These investigations are summarized in Sections 1.7.1 and 1.7.2. In 1992, EPA performed a screening survey of offsite soils discussed in Section 1.5.1. Finally, in 1993, a team of EPA divers surveyed the bottom of the Lauritzen Channel and sampled sediment in a submerged barge and tank, which had been discovered previously by independent investigations conducted by PRPs (Parametrix 1991). The sampling indicated that the submerged objects were not sources of contamination.

In 1993, MSL completed an RI of marine sediment at the United Heckathorn site for EPA. The objectives of the RI were to delineate the areal and vertical extent of pesticide contamination in marine sediments in inner Richmond Harbor, to estimate the volume of contaminated sediment, and to characterize the geology of the sediment. In addition, biological testing was performed, and treatability tests were conducted to predict the probable quality of effluent derived from dewatered sediment. Sediment cores and grab samples were collected in the Lauritzen Channel, Santa Fe

a The Battelle/Marine Sciences Laboratory is part of the Pacific Northwest Laboratory, which is operated for the U.S. Department of Energy by Battelle Memorial Institute under Contract DE-AC06-76RLO 1830. 
Channel, Inner Harbor Channel, and Parr Canal. Core samples were analyzed for chlorinated pesticides to delineate the areal and vertical distribution of contamination. Sediments from selected cores were also analyzed for other contaminants. Sediment thickness and chemistry data were used to estimate volumes of sediment above various levels of contamination. Solid-phase toxicity and bioaccumulation tests were conducted for comparison with EPA's ecological risk assessment. The probable quality of effluent produced by dewatering sediment was evaluated by chemical and toxicological testing of suspended-particulate-phase (SPP) and elutriate samples prepared from marine sediment. The nature and extent of pesticide contamination in marine sediments are summarized in Section 1.5.2. Treatability testing results are summarized in Section 1.8.

\subsubsection{Site Remediation Activities}

Interim response actions were conducted from 1982 to 1993 in the upland and embankment areas of the United Heckathorn site. Marine sediment has not been the subject of prior removal actions or otherwise remediated. As early as 1982, contaminated soil, asphalt, and concrete from the United Heckathorn site were excavated by the current landowner and moved to a nearby lot adjacent to the Parr Canal. These materials were subsequently taken to several hazardous waste disposal facilities. In 1983, soils known to contain high levels of pesticides were removed by the current landowner during routine maintenance and extension of onsite railroad lines. A 6-in. to 8-in. layer of gravel was placed over the surface of the site, including a 6-in. layer of ballast rock over the Lauritzen Channel embankment and selected areas of high DDT concentrations. In 1986, during excavation for the construction of a train scale, high levels of pesticides were detected and approximately 60 cubic yards (cy) of soil were removed by the current landowner.

In November 1990, pursuant to an EPA Removal Order (90-22), approximately 1500 cy of soil and visible pesticide residue containing up to 100\% DDT were excavated by several PRPs (Levin, Montrose, Parr, Shell, and Stauffer) from the Lauritzen Channel embankment. This excavation was taken back to the foundation of former Building 1, where a pesticide deposit approximately $3 \mathrm{ft}$ thick was revealed beneath the foundation. Samples of this deposit contained approximately $30 \%$ DDT. An additional $1800 \mathrm{cy}$ of pesticide residue and contaminated soil were excavated by the same PRPs from this area in April 1991. The excavated material and stockpiles that had been placed onsite in the 1980s were hauled offsite by truck to permitted disposal facilities. A final soil removal action was completed in May 1993 by the same PRPs as well as Prentiss and 
Sherwin Williams. Assuming that the embankment deposit contained 30\% DDT, over $99 \%$ of the mass of pesticides has been removed from the upland portion of the site since 1990.

\subsection{NATURE AND EXTENT OF CONTAMINATION}

The nature and extent of contamination at the United Heckathorn site have been delineated in previous site investigations and EPA's RI and are summarized below. The distribution of contaminants in the upland area is based on current site conditions following the removal actions described in Section 1.4.3. The distribution of contaminants in the marine sediment is based on the RI of marine sediment performed in 1993 (White et al. 1994).

\subsubsection{Distribution of Chemicals in the Upland Area}

As discussed in the site history, large deposits of extremely high levels of pesticides remained in upland soils after United Heckathorn ceased operations in 1966. These have been the subject of extensive excavation and removal actions over the past three years. The last hot-spots of pesticide contamination were excavated in May 1993, completing the removal of roughly $99 \%$ of the mass of pesticides from the upland portion of the site since 1990.

A soils database representing current site conditions was compiled in EPA's Human Health Risk Assessment (ICF Technology 1994) from the previous site studies and removal action reports. A conservative estimate of the remaining mean site soil concentrations of the primary COCs, DDT (total) and dieldrin, are 64 and 5.7 milligrams per kilogram $(\mathrm{mg} / \mathrm{kg})$, respectively. These estimates are conservative because the soils database includes the large number of additional samples which were taken to delineate the hot-spot areas for the removal actions. The actual mean site concentrations are likely to be lower. Estimates of mean site soil concentrations for contaminants of potential concern assessed in the human health risk assessment are given in Table 1.2.

DDT at levels exceeding $1 \mathrm{mg} / \mathrm{kg}$ in upland soils extends over the site as shown in Figure 1.5. The total mass of these upland soils is approximately 95,000 tons (Levine-Fricke 1993). Confirmation sampling performed during the excavations of the most contaminated areas indicated that the concentrations drop to nondetectable levels in the younger bay mud immediately below the upland soils, demonstrating that the homogeneous silty-clay bay mud underlying the site is an effective barrier to downward migration of site chemicals. 


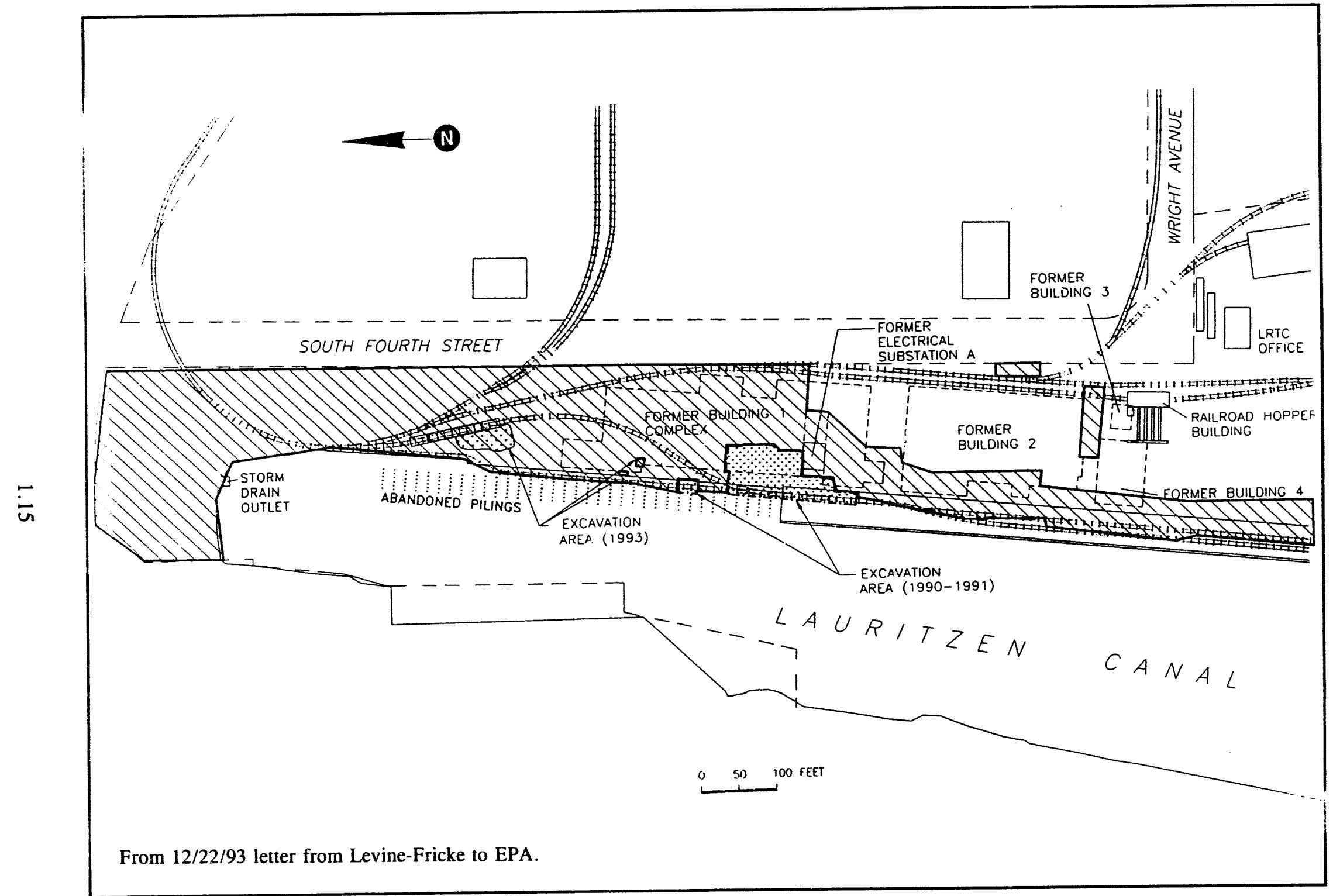

FIGURE 1.5. Upland Soils with Pesticide Concentrations Exceeding 1 ppm 
TABLE 1.2. Mean Upland Soil Concentrations for Potential Contaminants of Concern

\begin{tabular}{|c|c|}
\hline Chemical & $\begin{array}{c}\text { Concentration } \\
\text { (mg/kg dry wt) }\end{array}$ \\
\hline Aldrin & 0.46 \\
\hline DDT (total) & 64 \\
\hline Dieldrin & 5.7 \\
\hline Endrin & 3.1 \\
\hline Lead & 440 \\
\hline
\end{tabular}

In 1992, EPA also performed a screening assessment of offsite soils (ICF Technology 1994) in order to determine whether the historic operations of United Heckathorn could have released pesticides into the air in sufficient quantities to cause levels of concern in nearby offsite residential soils. Sampling locations were chosen along Cutting Boulevard and immediately north of Highway 580 , because the meteorological analysis for EPA's 1988 air monitoring program indicated that the strongest prevailing winds at the site blow due north. The sampling program was therefore deliberately biased to target the area which would have had the highest levels of pesticides, had Heckathorn caused contamination. All sampling results were well within acceptable levels for protection of human health.

\subsubsection{Distribution of Chemicals in Marine Sediment}

The results of the RI of marine sediment indicate that the occurrence of pesticides at the site, particularly DDT and dieldrin, is more widespread and at concentrations orders of magnitude higher relative to San Francisco Bay background levels than other detected contaminants. The areal and vertical distribution of marine contamination is summarized below.

\section{Nature and Extent of Chlorinated Pesticide Contamination}

During the marine RI, 239 vertical core segments and channel edge grab samples were analyzed for chlorinated pesticides to delineate the areal and vertical extent of marine contamination. Results indicated that significant pesticide contamination was concentrated in the younger bay mud; samples from the older bay mud generally contained only traces of pesticides. In the Lauritzen Channel, the average concentration of total DDT in sediment decreased by two orders of magnitude 
from the base of the younger bay mud to the top of the older bay mud. Figure 1.6 presents the average total DDT concentration in the younger bay mud in the inner Richmond Harbor. It is significant to note that the concentration contours on this figure must be presented on a log scale in order to depict the gradient of six orders of magnitude between the Lauritzen Channel and the southern end of the Inner Harbor Channel. The maximum and median total DDT and maximum dieldrin concentrations throughout the study area are also shown. Pesticide concentrations were highest in the Lauritzen Channel, and decreased with increasing distance from the former United Heckathorn site, clearly indicating that Heckathorn was the source of contamination. The highest total DDT concentration of 633,000 micrograms per kilogram $(\mu \mathrm{g} / \mathrm{kg})$ dry wt was measured in a sample from $1 \mathrm{ft}$ to $3 \mathrm{ft}$ below the mudline in the center of the channel. Pesticide concentrations of greater than $100,000 \mu \mathrm{g} / \mathrm{kg}$ were detected in sediment from the northern and western portions of the channel. The median total DDT concentration was approximately $47,000 \mu \mathrm{g} / \mathrm{kg}$ at the head of the Lauritzen Channel, which has not been dredged in a number of years. The median concentration of total DDT decreased to about $14,000 \mu \mathrm{g} / \mathrm{kg}$ in the western, undredged portion of the channel, and to $1500 \mu \mathrm{g} / \mathrm{kg}$ in the dredged portion of the channel near the Levin terminal. Dieldrin concentrations were lower (maximum concentration of $16,000 \mu \mathrm{g} / \mathrm{kg}$ ), but exhibited the same spatial trend in relative concentration.

Total DDT concentrations in sediment decreased by at least two orders of magnitude from the Lauritzen Channel to the Santa Fe Channel. The median concentration of total DDT in the younger bay mud was $110 \mu \mathrm{g} / \mathrm{kg}$ in the upper Santa Fe Channel and $210 \mu \mathrm{g} / \mathrm{kg}$ in the federally maintained portion of the channel. DDT and dieldrin concentrations were higher in the federally maintained portion of the Santa Fe Channel, which includes the area downstream of the Lauritzen Channel. Total DDT and dieldrin concentrations decreased by another order of magnitude from the Santa Fe Channel to the Inner Harbor Channel. The median total DDT concentration was $60 \mu \mathrm{g} / \mathrm{kg}$ in the upper Inner Harbor Channel, and $10 \mu \mathrm{g} / \mathrm{kg}$ in the lower Inner Harbor Channel. The maximum total DDT concentration near Point Potrero was $19 \mu \mathrm{g} / \mathrm{kg}$, which is approximately equal to the median DDT concentration for the periphery of San Francisco Bay, excluding the Lauritzen Channel (Long et al. 1988).

Pesticide concentrations in Parr Canal sediment were lower than those measured in the Lauritzen Channel but greater than those measured in Santa Fe or Inner Harbor Channels. The 


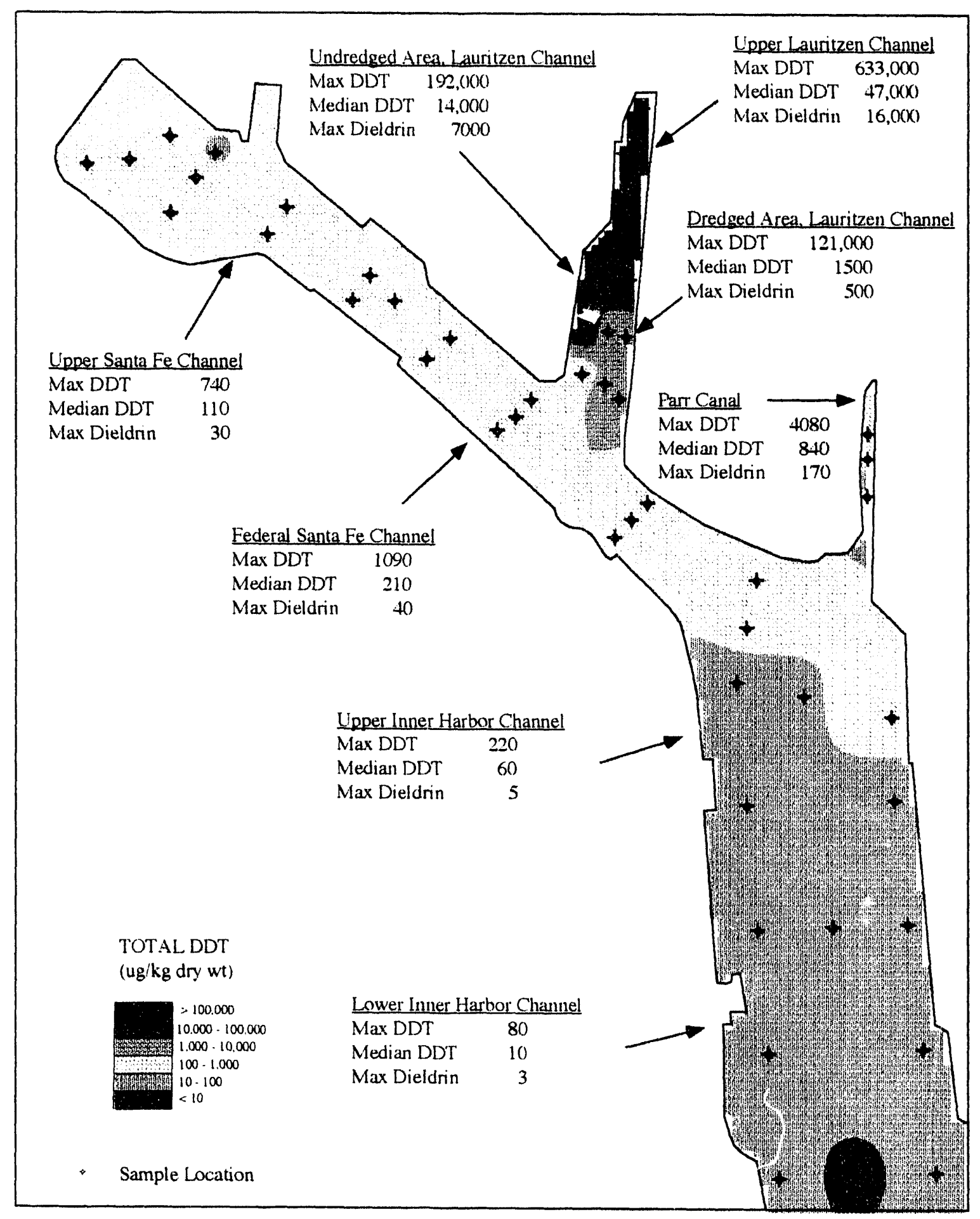

FIGURE 1.6. Average Total DDT in Younger Bay Mud, Inner Richmond Harbor 
maximum and median total DDT concentrations measured in Parr Canal sediment were $4080 \mu \mathrm{g} / \mathrm{kg}$ and $840 \mu \mathrm{g} / \mathrm{kg}$, respectively. The maximum dieldrin concentration was $170 \mu \mathrm{g} / \mathrm{kg}$.

Grab samples collected from channel edges throughout the study area showed the same spatial trend in pesticide concentrations as the core samples. The total DDT concentrations in channel edge samples were consistent with the median concentration measured in core samples from that area.

Vertical stratification in contaminant concentrations in the younger bay mud was generally not well developed. In the shallow portions of the Lauritzen Channel, contaminant concentrations increased, and then decreased with increasing depth. The most highly contaminated sediment was generally found from $1 \mathrm{ft}$ to $5 \mathrm{ft}$ below the mudline. In the Santa Fe Channel, the most contaminated sediment was found down-channel of the mouth of the Lauritzen Channel in the surface sediment, and just up-channel of the mouth in deeper sediment. Contaminant concentrations were generally higher in deeper sediment in the Inner Harbor Channel. The spatial trend in sediment pesticide concentrations delineated in the marine RI was consistent with previous investigations of Richmond Harbor and with the ecological risk assessment for the Heckathorn site.

The volumes of contaminated sediments and the average concentrations in harbor channels are shown in Table 1.3. These results demonstrate that $98 \%$ of the mass of DDT in harbor sediments is confined to the Lauritzen Channel.

\section{Other Contaminants}

Selected core samples collected during the marine RI were analyzed for polynuclear aromatic hydrocarbons (PAHs), polychlorinated biphenyls (PCBs), metals, and butyltins. Total PAH concentrations in younger bay mud composite samples from the Lauritzen and Parr Canals ranged from $750 \mu \mathrm{g} / \mathrm{kg}$ to $32,100 \mu \mathrm{g} / \mathrm{kg}$. PAH concentrations exceeded $20,000 \mu \mathrm{g} / \mathrm{kg}$ adjacent to the Levin terminal in the Lauritzen Channel, adjacent to the Castrol pier in the Santa Fe Channel, and in the center of the Parr Canal.

Aroclor 1254 was the only PCB detected in marine sediment samples from the United Heckathorn study area. PCB concentrations in the younger bay mud composite samples from the Lauritzen Channel and Parr Canal ranged from less than $45 \mu \mathrm{g} / \mathrm{kg}$ to $1980 \mu \mathrm{g} / \mathrm{kg}$. The highest values were measured in samples from the Parr Canal. 
TABLE 1.3. Estimated Volume of Younger Bay Mud and Average DDT Concentration

\begin{tabular}{|c|c|c|c|}
\hline Location & $\begin{array}{l}\text { Average Volume } \\
\text { (cy) }\end{array}$ & Standard Deviation & $\begin{array}{c}\text { Average } \\
\text { Total DDT } \\
(\mu \mathrm{g} / \mathrm{kg} \text { dry } w \mathrm{t})\end{array}$ \\
\hline Lauritzen Channel & 54,000 & 17,000 & 73,000 \\
\hline Parr Canal ${ }^{(\mathfrak{c})}$ & 10,000 & $\mathrm{NA}^{(\mathrm{d})}$ & 1000 \\
\hline Santa Fe Channel & 230,000 & 41,000 & 200 \\
\hline Inner Harbor Channel & $510,000^{(e)}$ & 37,000 & 70 \\
\hline \multicolumn{4}{|c|}{$\begin{array}{l}\text { (a) Average of three estimates. } \\
\text { (b) Sum of } 4,4^{\prime}-\mathrm{DDT}, 4,4^{\prime}-\mathrm{DDD} \text {, and } 4,4^{\prime}-\mathrm{DDE} \text {. } \\
\text { (c) Single estimate assuming a uniform younger bay mud thickness of } 6 \mathrm{ft} \text {. } \\
\text { (d) NA Not applicable. } \\
\text { (e) Average of two estimates. }\end{array}$} \\
\hline
\end{tabular}

Sediment samples were analyzed for 10 metals: silver, arsenic, cadmium, chromium, copper, mercury, nickel, lead, selenium, and zinc. In general, concentrations of six metals (arsenic, chromium, copper, mercury, nickel, and selenium) in the composite younger bay mud samples showed little spatial variation throughout inner Richmond Harbor. Concentrations of silver, cadmium, lead, and zinc were higher in samples from the head of the Lauritzen Channel and the Parr Canal than in samples from the Santa Fe and Inner Harbor Channels. Tributyltin concentrations in the younger bay mud composite samples from the Lauritzen and Parr Canals ranged from $5.3 \mu \mathrm{g} / \mathrm{kg}$ to $37.5 \mu \mathrm{g} / \mathrm{kg}$. Dibutyltin concentrations ranged from $4.5 \mu \mathrm{g} / \mathrm{kg}$ to $28.7 \mu \mathrm{g} / \mathrm{kg}$ dry wt.

In general, sediment from the upper Lauritzen Channel and Parr Canal had higher concentrations of PAHs, PCBs, and metals than sediment from the Santa Fe and Inner Harbor Channels. This is probably because the larger channels have been routinely dredged for navigation, whereas the northern Lauritzen and Parr have not. Concentrations of pollutants in Richmond Harbor are consistent with those found in central San Francisco Bay or other industrial harbors. Only the pesticides, DDT and dieldrin, are consistently found in sediments and biota at levels orders of magnitude higher than the regional background levels. 


\subsection{CONTAMINANT FATE AND TRANSPORT}

The physical and chemical properties of DDT and dieldrin control the distribution, mobility, and fate of these contaminants in the environment (Table 1.4). DDT is essentially nonvolatile, almost insoluble in water, and has a very high soil adsorption constant. It is highly persistent in the environment and tends to bioaccumulate in the fatty tissue of organisms. Dieldrin and DDT degradation products have similar properties. Potential pathways and mechanisms for the transport of pesticides from upland soils and marine sediments are discussed below.

\subsubsection{Fate and Transport of Pesticides in the Upland Area}

During United Heckathorn's operations, pesticide releases included direct discharges of waste streams to the bay, through discharges, spills and leaks to the ground and subsequent runoff to the bay, and releases to the air primarily by the generation of dust in the grinding process. Potential pathways for migration of the much lower concentrations of pesticides remaining in upland soils include transport to the air, groundwater, and surface water. Among these, only transport to surface water remains a pathway of potential concern. Emissions of chlorinated pesticides to the air could occur through particulate emissions caused by wind entrainment, vehicular traffic and construction. Volatilization is an additional route of air emission, although chlorinated pesticides are among the least volatile of all organic chemicals. EPA performed air monitoring on and offsite in 1988 (Ecology and Environment 1988). At the time, high levels of pesticides remained onsite, including a large, exposed deposit on the shoreline containing up to 100\% DDT. Even under those conditions, the air monitoring indicated that emissions of pesticides were below levels of potential health concern. As part of the human health risk assessment, modeling was done to estimate the potential for air releases under current site conditions, using conservative estimates of human exposure and dust generation. Again, predicted air emissions were well within acceptable levels.

As discussed in Section 1.3.1, the upland areas of the site are immediately adjacent to San Francisco Bay and consist of fill over the original intertidal mud flats (HLA 1986a). Shallow groundwater within some parts of the fill, particularly nearer the shoreline, is essentially bay water that varies in depth with the tidal cycle. The saturated thickness across the site is generally less than 18 in. The shallow groundwater is highly saline and unusable for water supply.

Transport of contaminants to shallow groundwater could occur through dissolution of chlorinated pesticides from soil particles. However, chlorinated pesticides have extremely low 
TABLE 1.4. Physical and Chemical Properties of DDT and Dieldrin ${ }^{(2)}$

\begin{tabular}{|c|c|c|c|c|c|}
\hline Property & DDE & DDD & DDT & Dieldrin & Significance \\
\hline $\begin{array}{l}\text { Log Octanol-Water } \\
\text { Partition Coefficient } \\
\text { (Log Kow) }\end{array}$ & 7.00 & 6.20 & 6.19 & 3.50 & $\begin{array}{l}\text { Measures extent of chemical partitioning } \\
\text { between octanol and water at } \\
\text { equilibrium. The higher the Kow, the } \\
\text { more likely a chemical is to partition to } \\
\text { octanol than to remain in water. Octanol } \\
\text { is used as a surrogate for lipids, so Kow } \\
\text { can be used to predict bioconcentration } \\
\text { in aquatic organisms. }\end{array}$ \\
\hline $\begin{array}{l}\text { Log Sediment-Water } \\
\text { Partition Coefficient } \\
\text { (Log Koc) }\end{array}$ & 6.64 & 5.89 & 5.39 & 0.61 & $\begin{array}{l}\text { Measures extent of chemical partitioning } \\
\text { between organic carbon and water at } \\
\text { equilibrium. The higher the Koc, the } \\
\text { more likely the chemical is to bind to } \\
\text { soil or sediment than to remain in water. }\end{array}$ \\
\hline $\begin{array}{l}\text { Solubility in Water } \\
\text { (ppb) }\end{array}$ & 100 & 40 & 5 & 195 & $\begin{array}{l}\text { Upper limit on chemical's dissolved } \\
\text { concentration in water. }\end{array}$ \\
\hline Henry's Law Constant & $6.80 \mathrm{E}-06$ & $7.96 \mathrm{E}-06$ & $5.13 \mathrm{E}-04$ & $5.80 \mathrm{E}-04$ & $\begin{array}{l}\text { Measures extent of chemical partitioning } \\
\text { between air and water at equilibrium. } \\
\text { The higher the constant, the more likely } \\
\text { a chemical is to volatilize than to remain } \\
\text { in water. }\end{array}$ \\
\hline
\end{tabular}


solubilities and extremely high soil adsorption coefficients. HLA (1986a) sampled groundwater and characterized groundwater flow as part of the first RI performed under state order. HLA found DDT concentrations varying from nondetectable to within the range of DDT's solubility. Using the groundwater flow and concentration data, HLA modeled transport of chemicals in groundwater to the bay and concluded that groundwater seepage could not cause violations of bay standards. HLA's modeling was intentionally conservative, probably by an order of magnitude, and did not consider readsorption, which would also greatly inhibit transport of hydrophobic pesticides through the soil. The state did not require groundwater monitoring in the subsequent site investigation performed for the property owner by Levine-Fricke. It should also be emphasized that roughly $99 \%$ of the mass of pesticides has been removed from upland soils since the HLA groundwater transport analysis was performed. Therefore, transport of contaminants through shallow groundwater is not considered a pathway of concern.

Deeper fresh water aquifers may exist below the older and younger bay mud layers, but these units are at least $50 \mathrm{ft}$ thick in the Richmond shoreline area and are very likely an impermeable barrier. As discussed above, confirmation samples taken beneath the excavations in the most contaminated areas indicate that pesticide concentrations drop to nondetectable levels near the surface of the young bay mud.

Finally, upland soil contaminants could be transported to surface waters and marine sediments through erosion. Although all known hot-spots of pesticide contamination have been removed, a large area of the site consisting of approximately 95,000 tons of soil has pesticide concentrations of over $1 \mathrm{mg} / \mathrm{kg}$, which exceeds the remedial action objectives established for marine sediments (see Section 2). Although these soils do not currently pose unacceptable risk to human health or the environment, preventing their erosion into the marine environment will be a site remediation goal.

\subsubsection{Marine Sediment Fate and Transport}

The dominant transport mechanism for DDT in the marine environment is the migration of fine-grained sediment, because DDT tends to bind to silt- and clay-sized particles. Contaminants can also move vertically in sediment by desorption, transport in porewater, and subsequent adsorption (porewater diffusion), or can disperse in the dissolved state by desorbing from sediment, being transported in solution, and later adsorbing back onto sediment. Porewater diffusion and dissolved-phase transport are not likely to be important processes at the Heckathorn site because of the extremely low solubility of pesticides. Thus, DDT-contaminated sediment can leave the site by 
1) exposure of contaminated sediment at the surface by vertical mixing, 2) resuspension of contaminated sediment, 3) transport, and 4) deposition.

The progressive burial of previously contaminated sediment does not necessarily prevent the dispersion of contaminants. Physical and biological processes can mix surface and subsurface sediment. Physical mixing due to wave resuspension is probably not significant in the protected waters of inner Richmond Harbor. Ship wakes and propeller-wash resuspend and mix sediment. Sediment can also be disturbed and subsequently mixed by the grounding of ship keels and propellers, by dredging and construction activities, or by liquefaction and slumping. Biological activity (bioturbation) can mix sediment over an interval of millimeters to tens of centimeters, depending upon the resident species. Consequently, the exposure of previously contaminated sediment at the surface depends upon the relative rates of deposition and vertical mixing.

Once contaminated sediments have been resuspended, they are transported by wind or tidal currents, which causes dispersal of the contaminants. Current speeds in Richmond Harbor are generally slow and are seldom capable of eroding fine sediment in the absence of other disturbances. Over the past 50 years, the periodic resuspension and transport of sediment out of the Lauritzen Channel have led to the gradual contamination of the Santa Fe Channel, and subsequently of the Inner Harbor Channel. If contaminated sediment were removed from or confined in the Lauritzen Channel, contaminant concentrations in Santa Fe and Inner Harbor Channels would be likely to slowly decrease over time.

The strong DDT and dieldrin concentration gradients indicate that the Lauritzen Channel is the source of contamination to the Santa Fe and Inner Harbor Channels. The primary source of DDT and dieldrin appears to be waste discharges to the channel during pesticide processing activities at the United Heckathorn site. The reduced level of contamination in surface sediment relative to subsurface sediment throughout most of inner Richmond Harbor suggests that the primary source of contamination to the system is no longer present. The need for occasional maintenance dredging indicates that net deposition occurs in Inner Richmond Harbor. Accumulation of sediment buries previously deposited contaminated material, and may result in a decrease in contamination in surface sediment over time if the source of contamination no longer exists. The higher surface concentrations in the Santa Fe Channel downstream of the Lauritzen Channel relative to subsurface sediment may be due to the removal of sediment from this area as part of maintenance dredging. 


\subsection{BASELINE RISK ASSESSMENT}

Risk assessments were conducted by EPA to evaluate the threat to human health and the environment posed by contamination from the United Heckathorn site. Results of these assessments are summarized below.

\subsubsection{Human Health Risk Assessment}

The baseline human health risk assessment for the site was performed by ICF Technology Inc. for EPA (ICF Technology 1994). The results indicate that among the various potential exposure pathways for site contaminants, only the consumption of fish poses risks that are above EPA's range of acceptability.

COCs at the site were selected for evaluation in the risk assessment using the site soil and sediment data collected by HLA (1986a), Levine-Fricke (1990, 1991b, 1993), and Weston (1993). The COCs selected for onsite soils were DDT (and metabolites), dieldrin, aldrin, endrin, and lead. Of these, DDT and dieldrin are the most prevalent contaminants and are the primary contributors to risk. COCs selected for sediments were DDT and dieldrin.

Six exposure pathways were identified as potential concerns at the site, as follows:

- ingestion and dermal adsorption of chemicals in onsite surface soils by workers at the site

- inhalation of fugitive dust from surface soils by onsite workers

- ingestion and dermal adsorption of chemicals in onsite surface and subsurface soils by temporary construction workers at the site

- inhalation of fugitive dust from soils by temporary construction workers at the site

- incidental ingestion and dermal adsorption of chemicals in offsite soils by nearby residents

- $\quad$ ingestion of contaminants in fish and shellfish from the Lauritzen, Santa Fe, and Inner Richmond Harbor Channels by fishermen and their families.

The onsite exposure pathways assume that the site will continue to be used for commercial or industrial uses in the future. This is in accordance with the Bay Conservation and Development Commission's (BCDC) San Francisco Bay Plan which designates the area for port priority or waterrelated industry use, and the City of Richmond's M-3 (heavy industry) zoning of the site and surrounding properties. 
The six potential exposure pathways were evaluated according to EPA guidance, which uses conservative estimates of chemical toxicity and exposure, and cumulative risk from the addition of pathways. Chemical concentrations used in the risk assessment included both average and either Reasonable Maximum Estimates (RME) of site concentrations or maximum measured values. EPA baseline human health risk assessments intentionally present conservative (i.e. health-protective) estimates of site risks. Actual risks are likely to be lower and may in fact be zero.

The assessments for onsite worker exposure and offsite residential exposure are even more conservative than usual because the soils databases in both cases were skewed toward higher values. The onsite soils database was skewed by the high number of samples taken to delineate the hot-spot excavation areas. Offsite soil screening samples were intentionally taken only in the immediate downwind area, which would have had the highest concentration had contamination occurred.

The cumulative risks calculated for the onsite soil exposure scenarios indicate that the removal actions that have occurred to date have reduced site concentrations of chlorinated pesticides to acceptable levels. The highest RME cancer risk calculated for the various onsite worker scenarios (ingestion, dermal adsorption and inhalation of fugitive dusts from surface soils by a permanent worker) is $1 \times 10^{-4}$, and the maximum Hazard Index (HI) for noncarcinogenic effects is 1 . More probable estimates for the same exposure scenario are $2 \times 10^{-5}$ and $<1$. Risks for other onsite worker scenarios are lower. Since the onsite soils database is skewed to produce conservative results and EPA's acceptable risk range is $10^{-4}$ to $10^{-6}$, onsite risks associated with chlorinated pesticides are acceptable.

Onsite risks for occupational exposure to lead were evaiuated using EPA's $500 \mathrm{mg} / \mathrm{kg}$ to $1000 \mathrm{mg} / \mathrm{kg}$ acceptable range for residential exposure, and the state of California's draft procedure for the assessment of adult exposure to lead in soil. Mean onsite lead levels are below $500 \mathrm{mg} / \mathrm{kg}$, and the RME lead concentration results in a 95th percentile adult blood lead level below the target concentration of 10 micrograms per deciliter $(\mu \mathrm{g} / \mathrm{dL})$ using the state's draft procedures. Therefore, onsite lead levels are acceptable.

Offsite residential risks for COCs in nearby soils were evaluated using the maximum values obtained in EPA's soil screening survey and conservative exposure assumptions, including childhood exposure. All results were well within the acceptable risk range for carcinogenic effects and below an $\mathrm{HI}$ of 1 for noncarcinogenic effects. 
Risks to fishermen and their families who consume fish caught in the inner Richmond Harbor were evaluated using information from two sources: fish tissue data generated as part of EPA's ecological assessment of the site, and community interviews with individuals who fish or are familiar with fishing practices in Richmond Harbor. The community interviews confirmed that fishing occurs regularly in Richmond Harbor, particularly at a site in the Inner Harbor Channel near the Parr Canal that has unrestricted access. Fishing in the Lauritzen Channel is restricted because it is surrounded by fenced industrial facilities, and fishing from boats is discouraged by warning signs in English, Spanish, Vietnamese and Laotian, posted under a 1986 order of the CDHS. Baseline risk assessments, however, assume that institutional controls, such as fences and posting, will be ineffective or not maintained. In fact, a person was photographed fishing from an industrial facility on the Lauritzen Channel during the EPA field sampling for the ecological assessment.

The results of the risk calculations indicate that the risks from long-term consumption of either whole fish or fillets of fish caught in the Lauritzen Channel are unacceptable. Using the exposure scenario which is the basis of the state's water quality objectives for recreational fishing, the lifetime excess cancer risk associated with site COCs is above $10^{-3}$ for consumption of whole fish, and above $10^{-4}$ for fillets. In the Santa Fe and Richmond Inner Harbor Channels, lifetime excess cancer risks due to DDT and dieldrin are within the acceptable range using the same exposure scenario.

On April 7, 1994, the California Department of Health Services issued an advisory against consuming any resident bottom fish, such as white croaker, from anywhere in the Inner Richmond Harbor. The primary risk associated with the consumption of fish caught outside the Lauritzen Channel is due to contamination with polychlorinated biphenyls (PCBs). The source of PCBs is unknown. PCBs are nut related to the United Heckathorn site, and may be present throughout the bay.

\subsubsection{Ecological Assessment}

The ecological risk assessment for the United Heckathorn site was performed by EPA (EPA 1994). The operations of United Heckathorn from 1947 to 1966 resulted in the release of DDT and other pesticides to the shoreline of the Lauritzen Channel and to San Francisco Bay. Today, in the waters of Richmond Harbor near the former plant, high levels of DDT remain in marine sediments, and DDT and dieldrin bioaccumulate in marine organisms to the highest levels found in the state of California. The goals of EPA's ecological assessment were to assess the threats posed to 
the environment by the contaminants released from United Heckathorn and to determine cleanup levels protective of the beneficial uses of San Francisco Bay.

The waters of Richmond Harbor are part of San Francisco Bay, the West Coast's largest estuary. The estuary sustains a complex ecosystem containirg thousands of species of fish, invertebrates, birds, mammals, insects, amphibians, plants and other life, as well as nearly half the waterfowl and shorebirds migrating along the Pacific flyway. Fish-eating birds, including cormorants, grebes, loons, kingfishers, and California brown pelicans (an endangered species) feed in the most contaminated channels at the site.

The initial components of EPA's ecological assessment included a review of previous studies in the area. Highlights of this review included the findings that sediment concentrations of DDT are elevated to acutely toxic levels in the Lauritzen Channel and decline by over four orders of magnitude to near background levels in the vicinity of Point Potrero. DDT and dieldrin concentrations are extremely elevated in transplanted mussels and resident invertebrates in the Lauritzen Channel and decline by two orders of magnitude in the Inner Richmond Harbor Channel. Fish caught in the Lauritzen Channel in 1986 contained extremely high levels of DDT, which were comparable to the levels measured in 1960. Finally, a study of migratory waterfowl in San Francisco Bay found that only those which wintered in Richmond Harbor significantly accumulated metabolites of DDT. Although other chemicals are present in Richmond Harbor, they are not consistently found at levels notably above background or above levels that are likely to cause toxicity, in marked contrast to DDT and dieldrin, which are many orders of magnitude above background and which were selected as the COCs for the study.

The next preliminary phase of the study was a review of the available standards, criteria, and scientific literature regarding ecological impacts of the COCs to determine as far as possible the contaminant levels in various media that could adversely impact sensitive organisms. This review indicated the ecological receptors likely to be the most sensitive and helped guide the selection of field and laboratory studies. The state's water quality objectives for DDT and dieldrin, identified in the California Enclosed Bays and Estuaries Plan (April 1991) and derived from EPA's ambient water quality criteria, were identified as applicable to the site. The marine chronic objective for DDT (1 nanogram per liter, $\mathrm{ng} / \mathrm{L}$ ) is based upon preventing bioaccumulation in fish to levels harmful to sensitive marine birds. 
The major phase of the study involved field and laboratory measurements of contaminant concentrations in various media and the performance of standard benthic tests for determining impacts from contaminated sediments. Most of the field samples were taken in October 1991. Additional fish and shellfish samples were taken in April 1992. The studies included bulk sediment toxicity testing, benthic community analyses, bioaccumulation testing, and chemical analyses in sediments, surface waters, and tissues of benthic organisms and fish and shellfish collected in trawls. An additional goal of these studies was the determination of the relationship between sediment contaminant concentrations and the concentrations in other media so that a sediment cleanup concentration could be determined which would result in the attainment of water quality objectives and protective contaminant levels in fish and shellfish tissues.

The results of the studies are summarized below. The total DDT levels measured in surface water from the Lauritzen, Santa Fe and lower Richmond Inner Harbor Channels were $50 \mathrm{ng} / \mathrm{L}$, $9 \mathrm{ng} / \mathrm{L}$, and $1 \mathrm{ng} / \mathrm{L}$, respectively. The dieldrin concentrations were $18 \mathrm{ng} / \mathrm{L}, 2 \mathrm{ng} / \mathrm{L}$, and nondetectable, respectively. These results indicate that the state's water quality objectives are violated in the Lauritzen and Santa Fe Channels, but are achieved in the lower Inner Harbor Channel. Analysis of water-to-sediment ratios indicates that the Lauritzen is a source of contamination to the other channels.

Sediment concentrations of total DDT declined from over $50 \mathrm{mg} / \mathrm{kg}$ in the Lauritzen Channel to $12 \mu \mathrm{g} / \mathrm{kg}$ near Point Potrero. Dieldrin concentrations declined from $570 \mu \mathrm{g} / \mathrm{kg}$ in the Lauritzen to nondetectable levels in the Inner Harbor Channel. These results are consistent with those of previous researchers, and with the more recent and extensive RI of marine sediments (White et. al 1994).

In 28-day bioaccumulation tests using Macoma nasuta, tissue levels of DDT over $50 \mathrm{mg} / \mathrm{kg}$ (dry wt) and $1.5 \mathrm{mg} / \mathrm{kg}$ dieldrin were obtained using Lauritzen Channel sediments. Tissue levels declined to $80 \mu \mathrm{g} / \mathrm{kg}$ DDT and undetectable levels of dieldrin using sediments from the vicinity of Point Potrero. These results are consistent with those of previous researchers. Further studies revealed that the tissue concentrations obtained at 28 days were approximately half those obtained after a 90-day exposure.

Tissue residues of DDT and dieldrin measured in field-collected benthic infauna were as high as $46 \mathrm{mg} / \mathrm{kg}$ and $2.5 \mathrm{mg} / \mathrm{kg}$ (dry wt), respectively, in the Lauritzen Channel. Concentrations dropped by about two orders of magnitude in the Inner Harbor Channel. 
Tissue residues of DDT and dieldrin measured in mussels (Mytilus sp.) were $2.6 \mathrm{mg} / \mathrm{kg}$ and $97 \mu \mathrm{g} / \mathrm{kg}$ (wet wt) in the Lauritzen Channel, and declined to $40 \mu \mathrm{g} / \mathrm{kg}$ and $5 \mu \mathrm{g} / \mathrm{kg}$ in the lower Richmond Inner Harbor Channel. These results are consistent with those of the State Mussel Watch program. Tissue levels in the lower Inner Harbor Channel are higher than would be predicted from the underlying sediment concentration indicating that there is water-column transport of pesticides from the source to less contaminated areas.

Tissue residues of DDT measured in whole fish (shiner perch) were over $10 \mathrm{mg} / \mathrm{kg}$ in the Lauritzen Channel, roughly $1 \mathrm{mg} / \mathrm{kg}$ in the Santa Fe Channel, and roughly $0.1 \mathrm{mg} / \mathrm{kg}$ in the Richmond Inner Harbor Channel. Dieldrin levels were roughly $0.6 \mathrm{mg} / \mathrm{kg}, 0.04 \mathrm{mg} / \mathrm{kg}$, and $0.002 \mathrm{mg} / \mathrm{kg}$ in the respective channels. The contaminant concentrations in fish from the Lauritzen Channel are in the same range as those measured in the 1960s, and exceed the levels that may cause adverse impacts to sensitive predatory birds by orders of magnitude. A sensitive bird, which had no other source of DDT in its diet and which consumed more than $0.5 \%$ to $1.5 \%$ of its diet from the Lauritzen Channel, could be adversely affected. These concentrations may also cause direct toxic impacts such as reduced fry survival in fish. The results for the Santa Fe Channel are an order of magnitude lower, but still exceed levels that may cause adverse impacts to sensitive fish-eating birds. A sensitive bird that consumed more than $5 \%$ to $15 \%$ of its diet from the Santa Fe Channel might be adversely affected.

Sediment toxicity tests using the amphipod, Eohaustorius estuarius, indicated significant acute toxicity in sediments from the Lauritzen Channel. Sediments from the Santa Fe Channel displayed lower but significant toxicity relative to the amphipod's native Yaquina Bay, Oregon, sediment, but were not significantly different from those in the Inner Harbor Channel or other San Francisco Bay locations. DDT was determined to be the primary cause of toxicity in the Lauritzen Channel. Additional toxicity tests conducted during the RI using the amphipod, Rhepoxynius abronius, confirmed the acute toxicity of Lauritzen Channel sediments. In four of five Lauritzen Channel composite samples, there was no survival of test organisms, an extremely rare occurrence indicating severe toxicity. Amphipod survival in samples beginning at the southern end of the Lauritzen Channel and proceeding out the harbor was not significantly different than survival in the San Francisco Bay fine-grained sediment control, indicating that the toxicity is confined to the Lauritzen.

An analysis of benthic infauna indicated that amphipod abundance (with the exception of the pollutant-tolerant Grandidierella japonica) was inversely related to DDT concentration. The 
minimum benthic ecological effects concentration was determined to be $100 \mu \mathrm{g}$ DDT/g organic carbon (equivalent to $1.9 \mathrm{mg} / \mathrm{kg}$, dry wt, at $1.9 \%$ organic carbon).

Overall, the results indicate that the gross contaminant levels in the Lauritzen Channel threaten a variety of ecological receptors at various trophic levels, including benthic and water-column organisms and fish-eating birds. Effects are likely to be much less severe in the Santa Fe Channel, although the contaminant levels in fish are significantly higher than the levels that may threaten sensitive fish-eating birds. In the Richmond Inner Harbor Channel, the DDT levels in fish $(100 \mu \mathrm{g} / \mathrm{kg})$ are between the level that is the basis of the state's chronic marine water quality objective intended to protect marine birds $(150 \mu \mathrm{g} / \mathrm{kg})$, and the National Academy of Sciences (NAS) recommendation $(50 \mu \mathrm{g} / \mathrm{kg})$ for protecting marine birds. It is clear from the results above that the most sensitive ecological receptors to sediment organochlorines in Richmond Harbor are likely to be fish-eating marine birds.

The only contaminated medium for which applicable regulatory criteria were identified is surface water. Nonregulatory or surrogate criteria were also identified for fish and shellfish tissues and sediments. Fortunately, surface water concentrations were found to be quite consistent during different tidal cycles and seasons in each of the three channels sampled. In addition, the concentrations measured in the water column and the concentrations measured in whole fish were found to agree remarkably with the concentrations predicted by the applicable EPA marine chronic water quality criteria and state water quality objectives. This demonstrates that total DDT present in surface waters is bioavailable, and that it accumulates as predicted by the applicable marine chronic criteria.

The analysis of surface water pesticide concentrations in the three channels indicates that the concentrations in the Santa Fe and Richmond Inner Harbor Channels are likely elevated by approximately one order of magnitude over the concentrations that would result from the respective local sediment concentrations, due to the flux of contaminated water from the Lauritzen Channel. This indicates that remediation of the Lauritzen would have beneficial effects throughout the Inner Harbor.

The final goal of the ecological assessment was to provide sufficient information to develop site remediation goals for sediments containing the COCs, DDT and dieldrin, which would be protective of human health and the environment. Although DDT and dieldrin co-occur, the DDT concentration is generally 10 to 100 times higher, and DDT is readily measureable over a wider area. 
Sediment remediation goals, which are expected to attain protective levels for both contaminants, have therefore been established based on DDT concentration. As indicated above, it was determined that the minimum ecological effects concentration for benthic organisms was $100 \mu \mathrm{g} \mathrm{DDT} / \mathrm{g}$ of organic carbon, which is equivalent to $1.9 \mathrm{mg} / \mathrm{kg}$ (dry wt) at $1.9 \%$ organic carbon. Sediment concentrations exceeding this value might cause local chronic adverse impacts to benthic organisms. EPA has reviewed data for other DDT-contaminated sites, and found a similar threshold for benthic effects.

Analysis of the Lauritzen Channel data indicates that the marine chronic water quality criteria and state objective of $1 \mathrm{ng} / \mathrm{L}$ is likely to be achieved if the average channel sediment concentration is below $1 \mathrm{mg} / \mathrm{kg}$ DDT (dry wt); and the human health criteria and objective of $0.6 \mathrm{ng} / \mathrm{L}$ is likely to be achieved if the average sediment concentration is below $590 \mu \mathrm{g} / \mathrm{kg}$. The NAS action level for fisheating birds, which is not a regulatory criterion, is likely to be achieved if the average channel sediment concentration is below $420 \mu \mathrm{g} / \mathrm{kg}$. In contrast to the minimum benthic effects concentration, the potential sediment remediation goals to achieve surface water criteria are a result of the particular hydrologic conditions in the Inner Richmond Harbor and are not likely to be widely applicable.

Sediment concentrations in the Lauritzen and Channel and Parr Canal exceed the level discussed above for protecting benthic organisms and for achieving the aquatic life and human health water quality criteria and NAS action level in fish for the protection of marine birds and mammals. The maximum sediment concentrations in Santa Fe and Richmond Inner Harbor Channels do not exceed the level for protecting benthic organisms, and the channel average concentrations do not exceed the level for achieving the water quality criteria and NAS action level in fish. Although the concentrations of pesticides in upland soils are acceptable for human exposure, they exceed the protective levels for sediments in the adjacent channels, indicating that erosion of upland soils and stormwater runoff to the marine environment should be prevented.

\subsection{TREATABILITY TESTING}

Treatability testing was conducted as part of the marine RI to assist in the evaluation of remedial alternatives. The probable quality of effluent produced by dewatering sediment during confined disposal operations was evaluated by chemical and toxicological testing of SPP and elutriate samples derived from sediment composites throughout inner Richmond Harbor. The USACE modified elutriate test (Palermo 1986, Palermo and Thackston 1988) was used to predict the dissolved and particulate-associated contaminant concentrations in effluent by simulating confined disposal conditions. In addition, the effect of activated carbon treatment on contaminant concentrations in 
effluent was evaluated. Test results were also used to evaluate potential water quality impacts during dredging.

The results indicate that resuspension of sediment during dredging of the Lauritzen Channel is likely to contribute to violations of state water quality objectives for DDT and dieldrin. Therefore, if dredging is selected for site remediation, effort should be made to minimize resuspension of sediment or spillage during handling, and barriers, such as silt curtains, should be used to isolate the dredging areas from the rest of the harbor. The state water quality objectives are currently exceeded in the Lauritzen Channel by approximately 100 -fold, and they would not be achieved during dredging. The goal would be to achieve the state objectives after remediation.

The results also indicate that if a confined disposal facility were constructed to settle and contain dredged sediments, settling alone may not be sufficient to reduce contaminant concentrations adequately to allow direct discharge. Although physical separation (by centrifugation) generally reduced contaminant concentrations in the treatability study, during actual remediation treatment using granular activated carbon (GAC) or other methods may also be required. Cost estimates for alternatives involving construction of confined disposal facilities will therefore also include GAC treatment.

\subsection{REMEDIAL INVESTIGATION SUMMARY}

The RI of the United Heckathorn site has been an iterative process, which began with studies conducted under state orders in the 1980s and includes the results of recent EPA-ordered soil removal actions, offsite soil sampling, human health and ecological risk assessments, and detailed marine sediment characterization. The overall results of the RI are summarized as follows:

- Soil removal actions from 1990 to 1993 have removed approximately $99 \%$ of the mass of pesticides from upland areas, and reduced onsite risks to acceptable levels for commercial and industrial use.

- Air, groundwater, and offsite soil sampling and modeling indicate that these are not exposure pathways of concern.

- Sediment DDT concentrations in the Lauritzen Channel are four to six orders of magnitude higher than the San Francisco Bay background. Approximately $98 \%$ of the mass of DDT in Richmond Harbor is contained in the Lauritzen Channel. 
- Contaminant concentrations in fish and shellfish from the Lauritzen Channel exceed limits for human consumption. Concentrations drop by one and two orders of magnitude, in the Santa $\mathrm{Fe}$ and Richmond Inner Harbor Channels.

- Lauritzen Channel sediments are acutely toxic to benthic marine organisms. DDT and dieldrin bioaccumulate in channel organisms to the highest levels found in the State Mussel Watch program. Fish-eating birds, including endangered brown pelicans, have been observed feeding in the most contaminated areas of the site, and DDT levels in fish exceed acceptable levels for consumption by birds by two orders of magnitude.

- DDT and dieldrin concentrations in Lauritzen Channel surface water violate EPA ambient water quality criteria, and because of transport, also cause violations in the Santa Fe Channel.

- $\quad$ EPA ambient water quality criteria for both DDT and dieldrin are expected to be achieved, and benthic and water-column organisms, fish-eating birds, and fishermen protected, if sediments are remediated in channels where the mean DDT concentration exceeds $420 \mu \mathrm{g} / \mathrm{kg}$ (dry wt). Both the Lauritzen Channel and Parr Canal exceed this criteria. The Santa Fe and Richmond Inner Harbor Channel do not.

- Contamination is confined to softer younger bay mud, and has not migrated into the underlying older bay mud. The volume of contaminated sediment in the Lauritzen Channel and Parr Canal is approximately $65,000 \mathrm{cy}$. 


\subsection{REMEDIAL ACTION OBJECTIVES}

The first step in the process used to develop and evaluate remedial alternatives for the United Heckathorn site is to develop remedial action objectives that specify the contaminants and media of interest, potential exposure pathways, and remediation goals. Remedial action objectives are developed on the basis of RI results, ARARs, and other risk-related factors. In this section, ARARs for the United Heckathorn site are identified, and remedial action objectives for the upland/embankment areas and marine sediment are specified. Based on the remedial action objectives, the volume of marine sediment requiring remediation is estimated.

\subsection{APPLICABLE OR RELEVANT AND APPROPRIATE REOUIREMENTS}

SARA (P.L. 99-499) requires that remedial action at Superfund sites achieve a cleanup level that protects human health and the environment. In addition, cleanups must attain "legally applicable or relevant and appropriate" requirements (ARARs) which are promulgated under federal or state law, unless a waiver is warranted.

An applicable requirement is a promulgated federal standard, requirement, criterion, or limitation that specifically addresses a hazardous constituent, remedial action, location, or other circumstance at a CERCLA site. Promulgated state environmental requirements are also ARARs if they are more stringent than federal requirements.

A relevant and appropriate requirement is a promulgated federal or state requirement that addresses problems or situations sufficiently similar to those encountered at a Superfund site, even though the requirement is not legally applicable. A requirement may be relevant but not appropriate given site-specific circumstances; such a requirement would not be an ARAR for the site. A requirement, or part of a requirement, that is considered to be relevant and appropriate must be satisfied to the same degree as if it were applicable.

Nonpromulgated advisories or guidance are referred to as "to-be-considered" criteria (TBCs) that may also be incorporated into the evaluation of potential remedies. Superfund remedies are not required to meet TBCs, but they may be used in the selection of remedies in the absence of applicable or sufficiently protective ARARs. 
There are three general types of ARARs: chemical-specific, location-specific, and action-specific. Chemical-specific ARARs are usually health- or risk-based concentration limits for specific hazardous substances in various environmental media (e.g., soils and sediments). Location-specific ARARs impose restrictions on certain types of activities, based on site characteristics. Action-specific ARARs are requirements triggered by the type of remedial activities under consideration. Federal and state environment laws often do not neatly fall into one category; consequently, the discussions below may, for example, address chemical-specific requirements that are also action dependent, or laws that are both chemical- and location-specific.

Section 121(e) of SARA states that federal, state, and local permits are not required for the portion of any removal or remedial action conducted entirely onsite, when the action is selected and carried out in compliance with Section 121 of SARA. However, the substantive requirements of federal, state, or local environmental law must be met. "Onsite" is defined as the areal extent of contamination and all suitable areas in very close proximity to the contamination necessary for implementation of the response action (40 CFR 300.5 and $300.400[\mathrm{e}][1])$.

\subsubsection{Chemical-Specific Requirements}

Chemical-specific ARARs are often health- or risk-based standards applicable to a particular medium, which may be used to establish site remediation goals. The only chemical-specific ARARs identified as remediation goals for the United Heckathorn site are the state's water quality objectives and the equivalent EPA ambient water quality criteria, which limit the allowable concentrations of chemicals in surface waters. These standards were established to protect aquatic and wildlife and fisherman. The NAS action levels for pesticides in fish were identified as a TBC, which provides additional protection to piscivorous marine birds. Additional chemical-specific ARARs and TBCs were identified that would apply to, or would affect, certain types of remedial actions.

\section{Surface Water}

ARARs for surface water include EPA's ambient water quality criteria for DDT and dieldrin. These will be used as the primary basis for the site remediation goals.

EPA Ambient Water Quality Criteria. Section 304 of the Clean Water Act required EPA to publish criteria for water quality that accurately reflect the latest scientific knowledge on the kind and extent of all identifiable effects on health and welfare, including effects on plankton, fish, shellfish, wildlife, and plant life, that may be expected from the presence of pollutants in any body of water, 
based on the substances' whole-water concentration. The ambient water quality criteria for DDT and dieldrin were published in October 1980. The criteria for the protection of saltwater aquatic life and human health adopted as California's water quality objectives were based on EPA's criteria and are equivalent. The human health values have been updated since the original criteria publications in 1980 to reflect revised carcinogenic potency values from EPA's Integrated Risk Information System (IRIS) database (see Final Rule, 40 CFR Part 131, 57 FR 60848, December 22, 1992).

The derivation of EPA's ambient water quality criteria is discussed at length in the ecological assessment (EPA 1994). Criteria for the protection of saltwater aquatic life are, for most pollutants, based upon toxic effects data for water-column organisms. However, for DDT and its metabolites, which readily bioaccumulate and may cause toxicity to organisms at higher trophic levels, it was determined that more restrictive criteria were necessary to protect fish-eating birds. The chronic marine aquatic life criterion is $1 \mathrm{ng} / \mathrm{L}$, and the water quality criterion for the protection of human health from the consumption of fish is $0.59 \mathrm{ng} / \mathrm{L}$ (EPA 1980a).

The chronic marine aquatic life criterion for dieldrin of $1.9 \mathrm{ng} / \mathrm{L}$ is also residue-based, and was set at the level that would result in the achievement of the Food and Drug Administration's (FDA) action level for fish oil after bioaccumulation (EPA 1980b). This criterion is protective of sensitive aquatic organisms. The water quality criterion for the protection of human health from the consumption of fish is $0.14 \mathrm{ng} / \mathrm{L}$. The EPA aquatic life and human health water quality criteria for DDT and dieldrin are listed in Table 2.1.

Section 121(d)(2)(A)(ii) of CERCLA requires that remedial actions meet federal water quality criteria established under Section 304 or 303 of the Clean Water Act where such water quality

TABLE 2.1. EPA Ambient Water Quality Criteria

\begin{tabular}{|l|c|c|}
\hline Chemicals & $\begin{array}{c}\text { Saltwater Aquatic Life } \\
\text { 24-hour average } \\
\text { (ng/L) }\end{array}$ & $\begin{array}{c}\text { Human Health } \\
\text { (ng/L) }\end{array}$ \\
\hline \hline DDT $^{(a)}$ & 1.0 & 0.59 \\
\hline Dieldrin & 1.9 & 0.14 \\
\hline (a) The sum of the 4,4'- and 2,4'- isomers of DDT, DDD (TDE), and DDE. \\
\hline
\end{tabular}


criteria are determined by EPA to be relevant and appropriate to remedial actions at the site. See 42 U.S.C. $\$ 96121(\mathrm{~d})(2)(\mathrm{A})(\mathrm{ii})$ and 40 C.F.R. $\$ 300.430(\mathrm{e})(2)(\mathrm{i})(\mathrm{G})$. In evaluating whether specific water quality criteria are relevant and appropriate to remedial actions at Superfund site, CERCLA requires EPA to consider four criteria: 1) the uses of the receiving water body; 2) the media affected; 3) the purposes of the criteria, and 4) current information. See 42 U.S.C. $\$$ 96121(d)(B)(i). See also EPA, CERCLA Compliance with Other Laws Manual - CERCLA Compliance with the CWA and SDWA at 2 (OSWER Pub. 9234.2-06/FS, Feb. 1990).

EPA guidance concerning determinations that water quality criteria are relevant and appropriate to remedial action at a Superfund site provides that "a water quality criteria component for aquatic life may be relevant and appropriate when there are environmental factors that are being considered at a site, such as protection of aquatic organisms. With respect to the use of water quality criteria for the protection of human health, levels are provided for exposure both from drinking the water and from consuming aquatic organisms (primarily fish) and from fish consumption alone. Whether a water quality criterion is appropriate depends on the likely routes of exposure" (EPA 1989).

Both the marine chronic and human health water quality criteria for DDT and dieldrin are relevant and appropriate to remedial actions at this site because both aquatic life and wildlife and humans may be exposed to these contaminants either directly or through consumption of contaminated organisms. As discussed in the ecological assessment, aquatic organisms are present in all channels at the site, which are a part of San Francisco Bay. Fish-eating birds feed in al: channels in the harbor. In fact, the particular bird upon which the marine chronic water quality criterion for DDT was based is the California brown pelican, an endangered species, which has been observed feeding in the most contaminated channels at the site. As discussed in the human health risk assessment, fishermen catch and consume fish from the inner Richmond Harbor channels. In 1986, CDHS ordered the posting of the Lauritzen Channel to warn fishermen of the fish and shellfish contamination. Finally, the beneficial uses designated by the State of California for central San Francisco Bay waters, which are . discussed below, include fishing, wildlife habitat, preservation of rare and endangered species, fish migration, fish spawning, shellfish harvesting, and estuarine habitat. EPA's ambient water quality criteria were specifically developed to protect such beneficial uses. 


\title{
Porter-Cologne Water Quality Act. California Enclosed Bays and Estuaries Plan. San
}

Francisco Bay Regional Basin Plan, and Fish and Game Code. The state of California adopted water quality objectives for toxic pollutants pursuant to the requirements of Section 303 of the Clean Water Act and the Porter-Cologne Water Quality Control Act. The release of hazardous substances to surface waters is controlled under these statutes and implementing regulations, and the state Fish and Game Code (\$5650). The state's Enclosed Bays and Estuaries Plan, adopted on April 11, 1991 (State Water Resources Control Board Resolution No. 91-33, 1991), contains water quality objectives for DDT and dieldrin in surface waters that are equivalent to the EPA criteria listed in Table 2.1. These chemical-specific objectives apply to all surface waters of San Francisco Bay, including all channels and canals in Richmond Harbor.

The California Enclosed Bays and Estuaries Plan also contains the following narrative objective:

"The concentration of toxic pollutants in the water column, sediments, or biota shall not adversely affect beneficial uses."

The chemical-specific objectives were adopted in the Water Quality Control Plan for the San Francisco Basin (the Basin Plan) by SFBRWQCB (SFBRWQCB 1992). The Basin Plan also lists the following beneficial uses of Central San Francisco Bay, which includes the waters at the site:

\author{
Industrial Service Supply \\ Industrial Process Supply \\ Navigation \\ Water Contact Recreation \\ Non-contact Water Recreation \\ Commercial and Sport Fishing \\ Wildlife Habitat \\ Preservation of Rare and Endangered Species \\ Fish Migration \\ Fish Spawning \\ Shellfish Harvesting \\ Estuarine Habitat
}

Resolution 68-16: Statement of Policy with Respect to Maintaining High Quality of Waters in California. The State Water Resources Control Board adopted Resolution 68-16 on October 28, 1968. The Basin Plan, discussed above, states: "Whenever the existing quality of water is better than the quality of water established herein as objectives, such existing water quality shall be maintained unless otherwise provided by State Water Resources Control Board Resolution 68-16." The 
SFBRWQCB has identified Resolution 68-16 as a potential ARAR for the United Heckathorn Site. Although EPA does not agree that Resolution 68-16 is an ARAR, EPA and the State of California agree that achieving the water quality criteria identified above would meet the requirements of $68-16$, regardless of whether or not it is an ARAR.

\section{Soils and Sediments}

No chemical-specific ARARs have been identified as remedial goals for soils or sediments at the site. Based on the results of the ecological assessment, remediation goals for sediments were calculated to prevent violations of the ARARs for surface waters. EPA's proposed sediment quality criterion for dieldrin and the National Oceanographic and Atmospheric Administration's (NOAA) effects ranges are not ARARs, but were considered as potential TBCs and discussed at length in the ecological assessment. However, they were not selected as potential remediation goals.

Federal and state hazardous waste statutes and regulations are discussed below, and the state laws would be applicable to certain remedial actions. The SFBRWQCB's sediment screening criteria would also affect certain offsite remedial disposal options.

Resource Conservation and Recovery Act. EPA has developed chemical-specific criteria for the identification of hazardous waste under the Resource Conservation and Recovery Act (RCRA). For the COCs at this site, the criteria are not concentration-based, but are instead based on the source of the constituents (40 CFR 261.33). Product spills, for example, are RCRA-regulated, but generally releases of chemicals contained in process waste streams are not (40 CFR 261.33[d][comment]). Based on a review of historical documents, the presence of COCs in marine sediments and remaining soils appears to be due to releases contained in waste streams from United Heckathorn's processes; therefore, they are not RCRA wastes.

\section{California Code of Regulations, Title 22. The state of California has developed} chemical-specific regulatory criteria for the identification of hazardous and extremely hazardous wastes, based on Total Threshold Limit Concentration (TTLC) and Soluble Threshold Limit Concentration (STLC) values (California Code of Regulations, Title 22, Sections 66699 and 66723 ). Any waste containing a substance at a concentration equal to or exceeding a listed TTLC is classified as a hazardous waste by the California Department of Toxic Substances Control (DTSC). Extremely hazardous wastes are also classified by DTSC using TTLCs. STLCs are related to the Waste Extraction Test (WET), also described in Title 22. A waste is classified as hazardous by DTSC if it 
produces a WET text extract that exceeds an STLC. The TTLCs and STLCs for the major COCs at the site, DDT and dieldrin, are listed in Table 2.2.

All materials known to contain concentrations of substances exceeding the limits that classify extremely hazardous wastes have been removed from the site. Based on the results of previous investigations and the marine RI, approximately 95,000 tons of soils in the upland area of the site and approximately 65,000 cy of sediments in the Lauritzen Channel and Parr Canal exceed the California TTLC for DDT. No sediments outside these channels exceed the levels listed in Table 2.2.

Although the TTLCs and STLCs do not represent cleanup levels, soils and sediments with chemical concentrations higher than the TTLCs or STLCs would be classified as hazardous under California law if they were dredged or excavated from the site, potentially triggering action-specific ARARs, which are discussed in Section 2.1.3 of this report.

San Francisco Bay Regional Water Quality Control Board Sediment Screening Criteria. The SFBRWQCB released Sediment Screening Criteria and Testing Requirements for Wetland Creation and Upiand Beneficial Reuse, Interim Final in December, 1992. These are criteria used by the board to evaluate proposals for the reuse of dredged sediment, such as wetlands creation, levee restoration and daily cover for landfills. Since these activities would occur offsite, federal, state and local permits would be required.

The screening criteria contain no limits for dieldrin. The screening criterion for total DDT (dry wt) is $<0.003 \mathrm{mg} / \mathrm{kg}$ for wetlands creation cover, levee restoration, and landfill daily cover. This criterion is exceeded throughout Richmond Harbor, as well as in much of San Francisco Bay (the bay basin mean reported in the screening criteria document is $0.009 \mathrm{mg} / \mathrm{kg}$ ). The screening criterion for noncover wetlands creation is $0.1 \mathrm{mg} / \mathrm{kg}$ DDT. This criterion is exceeded throughout the Lauritzen Channel and the Parr Canal. Therefore, potential remedial actions that would involve

TABLE 2.2. State of California Hazardous Waste Limits

\begin{tabular}{|l|c|c|}
\hline \multicolumn{1}{|c|}{ Chemicals } & $\begin{array}{c}\text { TTLC } \\
\text { (mg/kg wet wt) }\end{array}$ & $\begin{array}{c}\text { STLC } \\
\text { (mg/kg wet wt) }\end{array}$ \\
\hline \hline DDT, DDD, DDE & 1.0 & 0.1 \\
\hline Dieldrin & 8.0 & 0.8 \\
\hline
\end{tabular}


beneficial reuse as a disposal option for sediment dredged from these channels are eliminated by the two criteria.

\section{Groundwater}

There are no chemical-specific ARARs for the concentration of COCs in site groundwater. Previous investigations found that salinity levels exceed federal (40 CFR 144.3) and state (State Water Resources Control Board Resolution No. 88-63) limits for underground sources of drinking water. Consequently, the groundwater at the site is not considered a potential source of drinking water as defined under state and federal law.

The state water quality objectives for surface waters discussed above do not apply to groundwater, although they might provide a basis for developing remediation goals in groundwater if there were a complete pathway by which contaminants in groundwater caused violations of the objectives in surface water. However, as discussed in the previous chapter, an analysis of groundwater transport to the bay was made in 1986 as part of the initial state-ordered site investigation. Although extremely high levels of pesticides were present in soils at that time, there were only sporadic detections of low levels of pesticides in groundwater samples, and modeling indicated that this potential pathway would not cause violations of surface water quality objectives. Based on this analysis, groundwater monitoring was not required in subsequent state-ordered site investigations. Subsequently, all highly contaminated soils containing approximately $99 \%$ of the mass of pesticides present during the groundwater sampling and modeling have been removed from the site.

Air

There are no chemical-specific ARARs, such as National Ambient Air Quality Standards or National Emission Standards for Hazardous Air Pollutants, for the concentrations of site COCs in the air. As discussed in Section 1.0, air monitoring was performed at the site prior to the removal of extremely high levels of exposed pesticides from site soils. Even under those conditions, the concentrations in onsite and offsite air were well below levels of concern. Bay Area Air District regulations regarding control of fugitive dust could apply to any remedial action, such as installation of a cap, that could potentially generate fugitive dust emissions.

\section{Fish and Shellfish}

There are no chemical-specific ARARs for the concentration of COCs in fish and shellfish. The NAS saltwater action levels are TBCs, which provide an additional level of protection to fish- 
eating birds beyond the level that is the basis of the surface water ARARs for aquatic life. The FDA action levels for the marketability of fish and shellfish are also TBCs for protecting human health, but they are much less stringent than the leveis that would be achieved by meeting the surface water ARARs discussed above.

National Academy of Sciences Water Quality Criteria. The NAS and National Academy of Engineering published recommendations in 1972 for DDT and dieldrin residues in composites of 25 or more whole fish of any species within the same size range as those consumed by any bird or mammal in the marine environment (EPA-R3-73-033, March 1973). The recommendations are listed in Table 2.3.

TABLE 2.3. National Academy of Sciences Saltwater Action Levels

\begin{tabular}{|l|c|}
\hline \multicolumn{2}{|c|}{ Residue Values in Whole Fish $(\mu \mathrm{g} / \mathrm{kg}$ wet $\mathrm{wt})$} \\
\hline \hline DDT (and metabolites) & 50 \\
\hline Dieldrin & 5 \\
\hline
\end{tabular}

The criteria document citer $n$,es demonstrating DDE induced shell thinning in mallards, American kestrels, Japanese quail and ring doves, and an inverse relationship between shell thickness and concentrations of DDE in eggs of wild populations of herring gulls, double-crested cormorants, great blue herons, white pelicans, brown pelicans, and peregrine falcons. The document concludes that a wet weight tissue range of $0.1 \mathrm{mg} / \mathrm{kg}$ to $0.5 \mathrm{mg} / \mathrm{kg}(100 \mu \mathrm{g} / \mathrm{kg}$ to $500 \mu \mathrm{g} / \mathrm{kg})$ is "evidently higher than one which would permit successful reproduction of several fish-eating and raptorial birds."

The criterion for dieldrin is based upon hazard to fish-eating birds such as the bald eagle, common egret, and peregrine falcon, "which may accumulate lethal amounts from fish or birds which have not themselves been harmed." The document states that dieldrin and closely related pesticides are substantially more toxic to wildlife than are other chlorinated hydrocarbon pesticides, so that more conservative recommendations are therefore necessary.

Food and Drug Administration Action Levels. The FDA action levels are guidance used to determine whether contaminated seafood and seafood products should be removed from the marketplace (Table 2.4). Commercial and sport fishing are designated beneficial uses of Central 
San Francisco Bay, which includes Richmond Harbor, under the San Francisco Bay Plan discussed in Section 2.1.1. Sport fishing is known to occur in the harbor, and some individuals interviewed for the human health risk assessment stated that limited commercial fishing occurs as well.

The FDA action levels are currently exceeded in some fish and shellfish in the Lauritzen Channel. However, sediment remediation required to achieve the FDA action levels would be less stringent than that required to meet the EPA ambient water quality criteria, which are ARARs.

TABLE 2.4. Food and Drug Administration Action Levels

\begin{tabular}{||l|c|c|}
\hline \multicolumn{1}{|c|}{ Chenical } & Food Type & Action Level $(\mu \mathrm{g} / \mathrm{kg}$ wet wt) \\
\hline \hline DDT (total) & Fish & $5000^{(\mathrm{a})}$ \\
\hline Dieldrin & Fish, shellfish, and fish oil & $300^{\text {(b) }}$ \\
\hline $\begin{array}{l}\text { (a) FDA Guideline 7420.08, 1978. } \\
\text { (b) FDA Guidelines 7420.08,1978 (fish and shellfish) and 7426.04, } 1977 \text { (fish oil). }\end{array}$ \\
\hline
\end{tabular}

\subsubsection{Location-Specific Requirements}

Location-specific ARARs are restrictions that are considered solely because of specific setting characteristics. Potential location-specific ARARs, such as the Endangered Species Act, the California Endangered Species Act, and the Archaeological and Historic Preservation Act, were considered.

Endangered Species Act. The goal of the Endangered Species Act of 1973, 16 USC $\$ 1531$ et seq., is the conservation of species of fish, wildlife and plants that are threatened with extinction. Compliance with the act at Superfund sites requires the identification of any threatened or endangered species or of its critical habitat that would be affected by a proposed remedial action.

The U.S. Fish and Wildlife Service (FWS), which is the federal trustee for the protection of migratory birds, provided a list of endangered species that are known to nest in central or northern San Francisco Bay, or are likely to feed regularly in the immediate vicinity of Richmond Harbor 
(Table 2.5). Among these, the California brown pelican has been seen by EPA personnel feeding in all channels in Richmond Harbor, including the most contaminated waterways.

The FWS raised the concern that the tissue residue basis $(0.15 \mathrm{mg} / \mathrm{kg}$ DDT in prey) of the surface water ARARs discussed in Section 2.2.1 resulted in reproductive levels in pelicans that were still $10 \%$ to $30 \%$ below the levels needed to maintain a stable population, described in the 1976 study used to set the criteria. It should be emphasized, however, that the reproductive effects occurred when contamination was widespread in the birds' range, and that the contamination in Richmond Harbor is restricted to a small area. Nevertheless, remediation to achieve the NAS saltwater action level for DDT in fish $(0.05 \mathrm{mg} / \mathrm{kg})$, which was identified as a TBC, would provide additional assurance of protection.

California Endangered Species Act. The goal of the California Endangered Species Act (California Fish and Game Code \$2050) is to conserve, protect, restore and enhance any endangered or threatened species and its habitat. Among the birds likely to nest or feed in the area, most of those that are listed as endangered or threatened by the state are also listed federally. The one exception is the California black rail, a state threatened species.

TABLE 2.5. Endangered Species

\begin{tabular}{||l|c|c|c||}
\hline \multicolumn{1}{|c|}{ Common Name } & $\begin{array}{c}\text { Nests In SF or San } \\
\text { Pablo Bays }\end{array}$ & $\begin{array}{c}\text { Feeds In/Around } \\
\text { Richmond Harbor }\end{array}$ & Prey \\
\hline Brown Pelican & & Yes & Fish $^{(\text {a) }}$ \\
\hline Bald Eagle & & & Omni. $^{\text {(b) }}$ \\
\hline Peregrine Falcon & Yes & Yes & Bird $^{\text {(c) }}$ \\
\hline Clapper Rail & Yes & & Invert. $^{\text {(d) }}$ \\
\hline Least Tern & Yes & Yes & Fish \\
\hline $\begin{array}{l}\text { (a) Fish: consumes primarily fish. } \\
\text { (b) Bird: consumes primarily birds. } \\
\text { (c) Omni.: diet usually omnivorous/scavenger. } \\
\text { (d) Invert.: consumes primarily small- to medium-sized invertebrates. }\end{array}$ \\
\hline
\end{tabular}


CDFG submitted the names of two potentially-affected plant species, both of which are listed as rare and have distributions in the north Bay and delta. They are Mason's lilaeopsis, a minute, turfforming perennial plant in the carrot family, and soft bird's-beak, a sparingly-branched, semi-parasitic herbaceous annual plant in the figwort family. The known distribution of Mason's lilaeopsis, which is found on saturated clay soils regularly inundated by waves and tidal action, appears to be limited to the bay delta. Soft bird's-beak occurs in the coastal salt marshes and brackish marshes of northern San Francisco and Suisun Bays.

The ARARs discussed in Section 2.1.1 are five orders of magnitude more stringent than necessary to protect aquatic plants. None of the potential remedies evaluated in this FS would involve destruction of rare plants or their habitat.

Archeological and Historic Preservation Act. The Archeological and Historic Preservation Act (16 USC \$469a-1) provides for the preservation of historical and archeological data that might otherwise be lost as a result of dam construction or alterations of the terrain. If any federal project might cause loss to significant scientific, prehistorical, or archeological data, the act requires the lead agency to preserve the data or request the Department of the Interior to do so.

The channels of Richmond Harbor were constructed this century by the dredging of mudflats and marshland. Remedial actions analyzed in this FS include the dredging of contaminated soft bay muds from these channels. No prehistoric or archeological artifacts are expected in these deposits, and none were found in the $\mathbf{5 3}$ sediment cores taken during the marine $\mathrm{RI}$.

\subsubsection{Action-Specific Requirements}

Action-specific ARARs are state or federal requirements that may be triggered by the type of remedial action undertaken at the site. For example, possible remedial actions may include the dredging and disposal of sediments from the Lauritzen Channel and Parr Canal. ARARs pertaining to these remedial actions generally limit disposal options. Possible additional action-specific ARARs are discussed in this section, and reviewed in greater detail in Section 4 (the detailed evaluation of remedial alternatives).

Coastal Zone Management Act (CZMA). Section 307(c)(1) of the CZMA requires that federal agencies conducting or supporting activities directly affecting the coastal zone conduct or support those activities in a manner that is consistent with approved state coastal zone management programs. Under CERCLA, onsite activities are not subject to administrative review or permitting 
processes, but they must be consistent with the substantive requirements of the coastal zone management plan. The approved coastal zone management program for San Francisco Bay includes the McAteer-Petris Act and the San Francisco Bay Plan, and is administered by BCDC.

The McAteer-Petris Act and the Bay Plan were developed primarily to halt uncontrolled development and filling of the bay. Their broad goals include reducing bay fill and disposal of dredged materials in the bay, and maintaining water quality and the ecological integrity of the bay. Generally, filling of the bay is allowable only when public benefits exceed public detriment from the loss of water areas, the filling is for a water-oriented use, and there is no alternative upland location available.

All remedial alternatives analyzed in this FS would affect the coastal zone. The consistency of each alternative with the state coastal zone management program is discussed in Section 4.0.

Section 404 of the Clean Water Act and Section 10 of the Rivers and Harbors Act. These federal laws, Section 404 of the Clean Water Act and Section 10 of the Rivers and Harbor Act, regulate dredging and filling in waters of the United States. Several of the remedial alternatives analyzed in this FS include dredging contaminated sediments. Some of the potential disposal options include filling in waters of the United States. USACE usually issues permits to conduct the above activities; however, since the actions analyzed in this FS would all occur onsite, permits would not be required, although the substantive requirements of the laws would still have to be met.

The determination of the acceptability of fill in waters of the United States is made under the Clean Water Act Section 404(b)(1) guidelines, which were promulgated in 40 CFR Part 230. The discharge of dredged or fill material is prohibited if there is a practicable alternative to the proposed discharge that would have less impact on the ecosystem, so long as the alternative does not have other significant adverse environmental consequences. Compliance with these requirements for each action alternative will be discussed in Section 4.0.

California Hazardous Waste Control Law. California's hazardous waste facility closure requirements, 22 California Code of Regulations, Chapters 14 and 15, "Closure and Post Closure," are not ARARs with respect to the upland portions of the United Heckathorn site because it is neither a hazardous waste facility nor a landfill. Some of the remedial alternatives analyzed in this FS would involve the consolidation and onsite containment of contaminated sediment. In the detailed analysis of alternatives, operational requirements found in Title 22 of the California Code of Regulations are 
discussed, including limited long-term management, site and cover maintenance, and institutional controls, including land use restrictions.

\section{$2.2 \quad$ REMEDIAL ACTION GOALS}

The remedial action goals for the United Heckathorn site are based on ARARs and the results of the human health and ecological risk assessments. Separate remediation goals have been established for marine and upland/embankment areas.

\subsubsection{Marine Area}

The remedial action goal for marine areas is the attainment for site COCs of EPA ambient water quality criteria for the protection of marine organisms and predators, and for the protection of human health. The EPA criteria are ARARs. They are listed in Table 2.6.

TABLE 2.6. Remedial Action Goals

\begin{tabular}{|l|c|c|}
\hline & $\begin{array}{c}\text { DDT } \\
(\mathrm{ng} / \mathrm{L})\end{array}$ & $\begin{array}{c}\text { Dieldrin } \\
(\mathrm{ng} / \mathrm{L})\end{array}$ \\
\hline \hline Marine Chronic Water Quality Criteria & 1 & 1.9 \\
\hline Human Health Water Quality Criteria & 0.6 & 0.14 \\
\hline
\end{tabular}

The water quality criteria are currently violated in the Lauritzen and Santa Fe Channels, and achieved in the Inner Harbor Channel. DDT and dieldrin co-occur, but DDT is present at much higher concentrations and is detectable over a much larger area. Therefore, it will be used to delineate proposed areas of site remediation for this FS.

The results of the marine sediment RI and ecological assessment indicate that the Lauritzen Channel is a source of pesticide contamination in other channels. Based on the DDT concentrations measured in the Lauritzen Channel, EPA has estimated that remediation of channel sediments to an average concentration of $1 \mathrm{mg} / \mathrm{kg}$ DDT (dry wt) will result in attainment of the marine water quality criteria of $1 \mathrm{ng} / \mathrm{L}$ in the water-column. Remediation of sediments to achieve an average concentration of $0.59 \mathrm{mg} / \mathrm{kg}$ total DDT will result in the attainment of the water quality criteria to protect fishermen. The non-regulatory NAS action level for the protection of fish-eating birds should be achieved by remediation of sediments in channels with an average concentration above $0.42 \mathrm{mg} / \mathrm{kg}$ total DDT. 
Based on the results of the detailed sampling in the marine RI, the sediment remediation levels above are currently exceed ' in younger bay mud in the Lauritzen Channel and Parr Canal. Therefore, the action alternatives analyzed in this FS will address remediation of younger bay muds in these two channels. If sediments in the Lauritzen and Parr are remediated, the highest remaining channel average DDT concentration will be $0.21 \mathrm{mg} / \mathrm{kg}$ in the Santa Fe Channel immediately outside the Lauritzen. At this concentration, the water column ARARs are expected to be achieved, the nonregulatory NAS action levels for the protection of marine birds should also be achieved, and there should be no benthic impacts.

\subsubsection{Upland/Embankment Areas}

The human health risk assessment found that upland and embankment areas of the site have already been remediated to acceptable levels for current and expected future uses. However, the upland soils are immediately adjacent to the Lauritzen Channel, and the average concentration of DDT remaining may be as high as $64 \mathrm{mg} / \mathrm{kg}$. This is two orders of magnitude higher than the remediation level chosen for channel sediments. Therefore, to ensure long-term protection of human health and the environment, the remedial action goal for upland and embankment soils is the prevention of erosion and transport into the Lauritzen Channel.

\subsection{VOLUME OF MARINE SEDIMENT REQUIRING REMEDIATION}

Based upon the results of the ecological assessment (EPA 1994) and the marine RI (White et al. 1994), EPA determined that remediation of contaminated sediments in the Lauritzen Channel and Parr Canal will protect human health and the environment and achieve compliance with ARARs. Vertical sampling conducted during the RI indicates that contaminant concentrations exceeding the levels necessary to meet the remedial action goals exist from the surface of the younger bay mud at the channel bottoms down to the older bay mud contact. High levels of the COCs have not migrated into the older bay mud.

The bathymetry of the Lauritzen Channel bottom and the surface of the older bay mud are shown in Figure 2.1. The vertical profiles of contaminant concentrations in the channel are shown in Figures 2.2 and 2.3. Using a number of approaches to calculate sediment volume that are discussed in the RI report, MSL estimated that the total volume of younger bay mud in the Lauritzen Channel is approximately 55,000 cy, and the volume in the Parr Canal is approximately 10,000 cy. Thus, the total volume of contaminated sediment that will be used in the analysis of alternatives is $65,000 \mathrm{cy}$. 


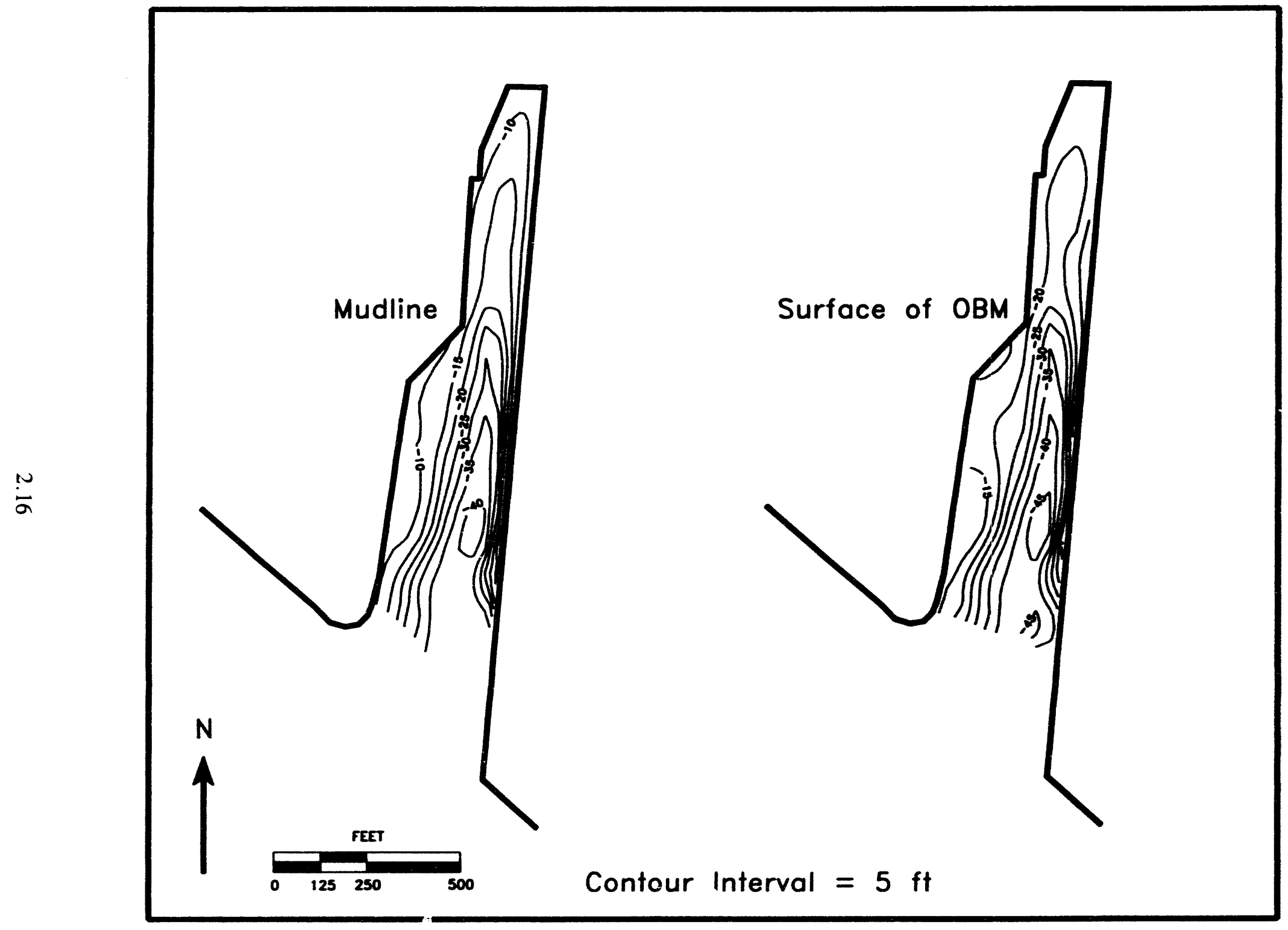

FIGURE 2.1. Elevation of the Mudline and Older Bay Mud Contact in the Lauritzen Channel 


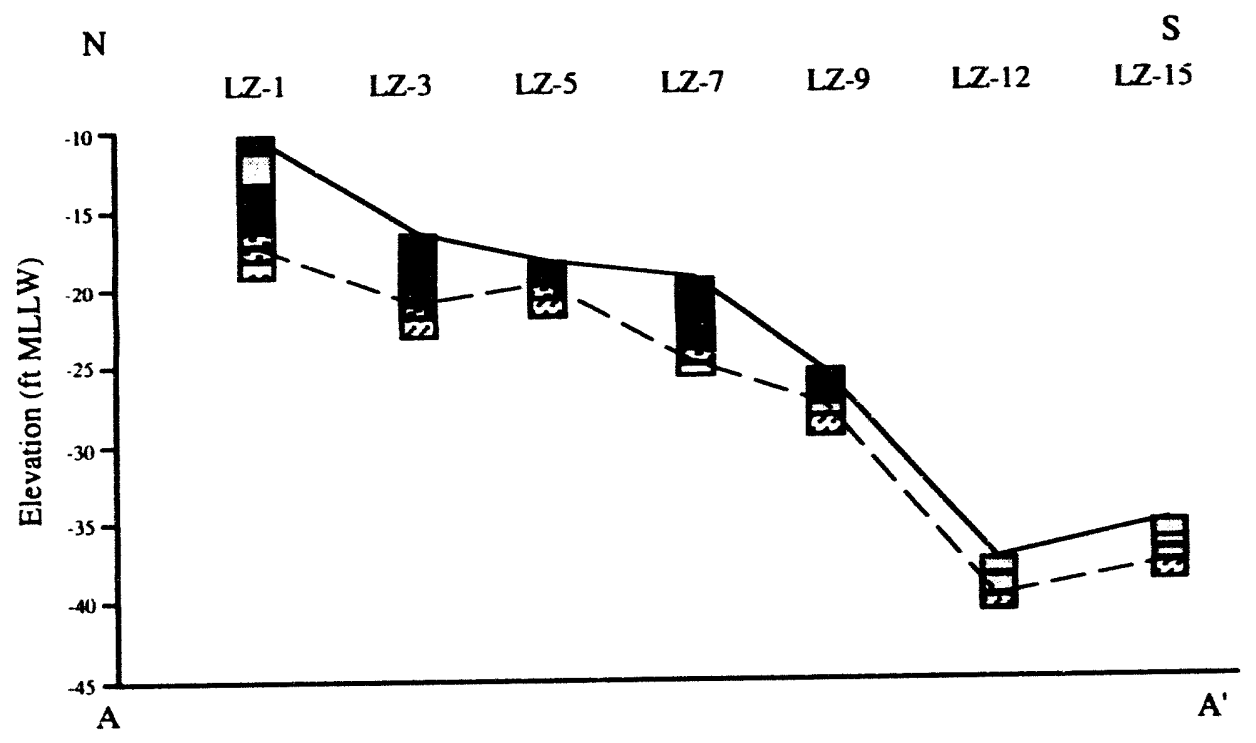

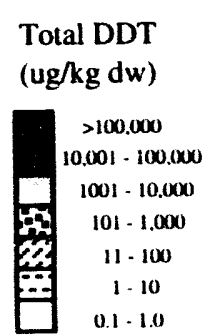

Vertical Exaggeration $=25 \mathrm{X}$

- - YBM/OBM Contact

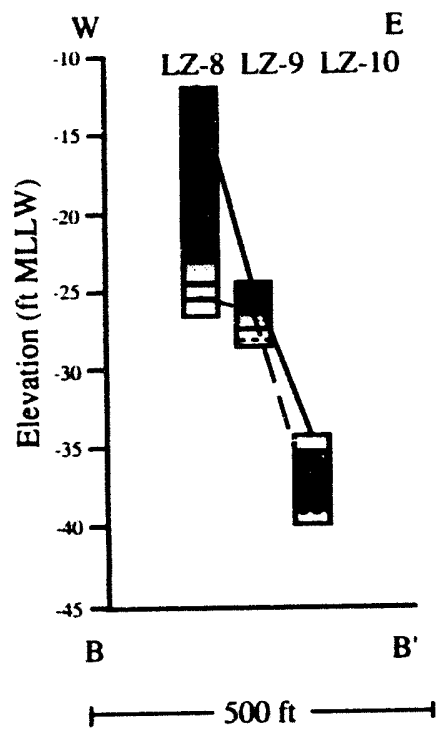

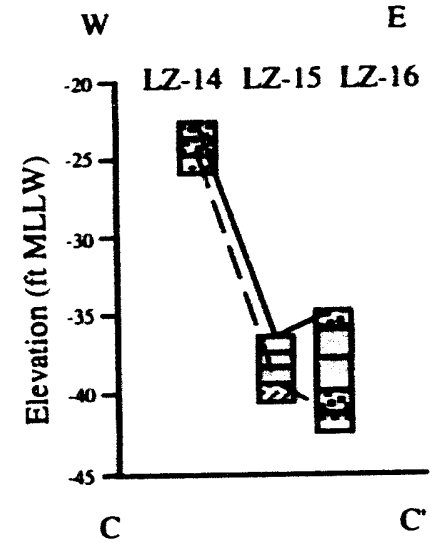

Cross-section locations are shown in Figure 2.3.

FIGURE 2.2. Cross-Sections of the Lauritzen Channel Showing Total DDT Concentrations 


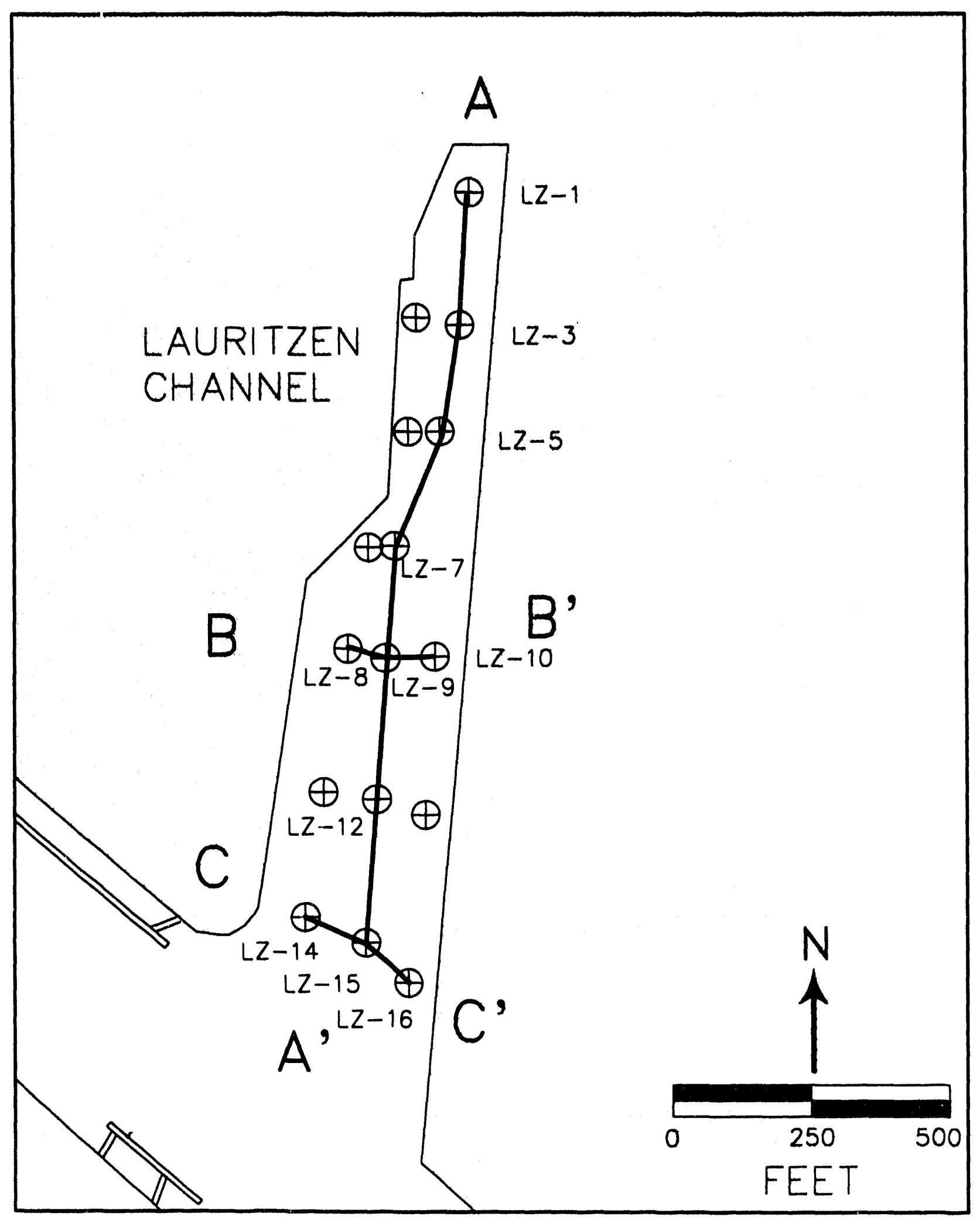

FIGURE 2.3. Cross-Section Locations 


\subsection{IDENTIFICATION AND SCREENING OF TECHNOLOGIES}

In this stage of the FS, general response actions and remedial technologies are identified, discussed, and screened on the basis of effectiveness, implementability, and cost. General response actions are various approaches that could be used to satisfy the remedial action objectives identified in Section 2.0 (e.g., removal, containment, or treatment). Remedial technologies are specific types of general responses. A general response action might be accomplished by several types of remedial technologies, and process options are specific methodologies within each technology type. For example, sediment treatment is a general response action, thermal treatment is a remedial technology, and incineration is a thermal treatment process option. The screening process is intended to eliminate remedial action technologies and process options that are inappropriate or infeasible for the contaminated media at the United Heckathorn site. Process options that are retained after screening will be combined into potential remedial alternatives for the site.

\subsection{GENERAL RESPONSE ACTIONS}

General response actions for contaminated media at the United Heckathorn site composed of institutional controls, containment, removal, treatment, and disposal. A final remedial action may combine several response actions. Each general response action is described below.

\subsubsection{Institutional Controls}

Institutional controls consist of land use and deed notices or restrictions, site access control, and site monitoring (i.e., sample collection and analysis). The human health risk assessment (Section 1.7) found that past actions had reduced upland soil contaminant concentrations to acceptable levels for the site's current and expected future commercial and water-related industrial uses. Although zoning regulations would prevent the site's conversion to residential use, a deed notice or restriction would provide additional assurance that such use would not occur without further health evaluation and possible additional remediation.

Site access restrictions consist of fencing and posting. The Levin Richmond Terminal is a private industrial facility which is fenced and has $24-\mathrm{h}$ security. The facility and the Lauritzen Channel are also posted with signs warning that channel sediments and fish and shellfish are contaminated. These signs are in English, Spanish, Vietnamese and Laotian. Although the signs may reduce the exposure of human receptors to contaminants, they do not affect ecological receptors. 
Site monitoring can be used to determine whether remedial action objectives have been achieved, to demonstrate the effectiveness and permanence of containment structures, or to assess environmental transport and impact if no action is taken. A site monitoring program will be implemented regardless of which final remedy is selected.

\subsubsection{Containment}

Containment can be used to prevent direct human or ecological exposure to contaminants, or to prevent migration of contaminants between media. General containment options include in-place capping, or full or partial removal and consolidation in an engineered disposal structure.

The remedial action objectives discussed in Section 2.0 include the prevention of erosion of upland soils to the marine environment and the remediation of contaminated sediment in the Lauritzen Channel and Parr Canal. The prevention of erosion of upland soils can be accomplished with a simple containment, such as an asphalt cap. Contaminated sediments may also be capped in place. In-place capping is most appropriate when burial, dilution, or biodegradation processes are rapid, when sediment will not be remobilized by human or natural activities, or when the environmental effects of cleanup would be more damaging than those of allowing the sediment to remain in place.

Confined Disposal Facilities (CDFs) are dammed or diked structures designed to retain dredged material. They may be constructed away from the water, partially in the water along a shoreline, or completely surrounded by water. CDFs are commonly used for sediment disposal. They are used to contain approximately $30 \%$ of the dredged material produced by the USACE Navigation Program (EPA 1993). The Port of Richmond has proposed a unique type of CDF using obsolete drydocks at its Point Potrero facility. These concrete basins are too small to service modern ships, but could potentially contain very large volumes of sediment if they were sealed off from the bay. Concrete vaults have been used elsewhere in the world for contaminated sediment disposal.

\subsubsection{Removal}

Various methods of dredging could be used to remove some or all of the contaminated sediments from the Lauritzen Channel and Parr Canal. Standard types of dredges include clamshell buckets and hydraulic dredges. There are also various special purpose dredges. The choice of dredge is affected by the amount of resuspension of sediment caused by the dredge, and the amount of water added to the dredged material. Silt curtains are often used in combination with dredging as turbidity barriers in order to confine any resuspended sediment to the excavation area. The removal 
option entails dredging contaminated sediments, and must be combined with containment or offsite disposal actions.

\subsubsection{Treatment}

Treatment involves the physical or chemical alteration of contaminated sediment to significantly and permanently reduce or eliminate its toxicity, mobility, or volume. Types of treatment which may be applied to contaminated soils or sediment are biological treatment, dechlorination, soil washing, solvent extraction, solidification, incineration, and thermal desorption. The effectiveness of treatment options are affected by the chemical properties of the contaminants as well as characteristics of the soil or sediment matrix such as clay content, humic content, salinity, and water content. Treatment options generally produce breakdown or byproducts that require further treatment or handling.

\subsubsection{Disposal}

If an onsite CDF is not constructed, dredged sediments can be transported offsite for disposal or possibly for re-use. Transportation could be accomplished by barge, rail or truck. Depending on the type of dredge used and the type of transportation available, processing or dewatering of sediment may also be required. In addition, a staging area or temporary disposal facility may be necessary if the transportation mechanism cannot handle the volume of dredged material as it is produced.

Offsite disposal locations sometimes used for dredged sediment, including bay or ocean disposal and beneficial re-use projects, are precluded by the concentration of contaminants in the Lauritzen Channel. Therefore, offsite disposal sites will be limited to permitted disposal facilities.

\subsection{SCREENING CRITERIA}

In the first step of the preliminary screening process, various remedial technologies are assessed by their potential to achieve the remedial action objectives given site-specific factors. Remedial technologies and process options are then evaluated on the basis of effectiveness, implementability, and cost. The site-specific factors are the nature of the waste material and the site characteristics, which are described below.

The identification, quantification, and characterization of the COCs and media in which they are located are necessary to assess the feasibility of a remedial action. Many remedial technologies cannot effectively remove contaminants that are strongly bound to small particles, whereas others 
have difficulty in processing fines (EPA 1993). The organic carbon content of sediment will control the bioavailability of contaminants and the amount of microbial activity. Waste characteristics are the physical and chemical characteristics of the COCs, the physical and chemical characteristics of the contaminated media, and the area and volume of material requiring remediation.

The COCs identified for the United Heckathorn site are total DDT (DDT, DDD, and DDE) and dieldrin. These pesticides are nonvolatile, nearly insoluble in water, and tend to adsorb to finegrained sediment particles (see Table 1.4). They are highly persistent in the environment and tend to bioaccumulate in the fatty tissue of marine organisms. These chemicals are associated with finegrained sediment in Inner Richmond Harbor.

The volume of marine sediment requiring remediation to achieve the remedial action goal is estimated to be approximately $65,000 \mathrm{cy}$ and consists of all of the younger bay mud from the Lauritzen Channel and Parr Canal. The younger bay mud occurs in a layer approximately $1 \mathrm{ft}$ to $10 \mathrm{ft}$ thick in these channels. The grain-size distribution and solids content of the younger bay mud are listed in Table 3.1 .

Site characteristics that influence the general feasibility of a remedial option for marine sediment are location and accessibility, resource availability, surface conditions, site security, and proximity to potential receptors. The United Heckathorn site is in an industrial area. Truck, rail, and ship access are good. Electricity, natural gas, and water are available. The site is an active shipping terminal with limited open and available space to use as a staging area. The upland area is level, and approximately five acres of open area are located adjacent to the Lauritzen Channel. Approximately three acres of open area are available adjacent to the Parr Canal. The area surrounding the Parr Canal is fenced and locked, and access to the Lauritzen Channel shoreline is restricted.

Technologies and process options which have the potential to achieve the remedial action objectives are developed and screened using the criteria described below. The no action alternative is retained for consideration in the final detailed analysis of alternatives without prior screening, in accordance with the requirements of the NCP. 
TABLE 3.1. Characteristics of Younger Bay Mud in the Lauritzen Channel and Parr Canal

\begin{tabular}{|l|c|c|c|c|c|c|}
\hline & $\begin{array}{c}\text { Mean } \\
\text { Percent } \\
\text { Gravel }\end{array}$ & $\begin{array}{c}\text { Mean } \\
\text { Percent } \\
\text { Sand }\end{array}$ & $\begin{array}{c}\text { Mean } \\
\text { Percent } \\
\text { Silt }\end{array}$ & $\begin{array}{c}\text { Mean } \\
\text { Percent } \\
\text { Clay }\end{array}$ & $\begin{array}{c}\text { Mean } \\
\text { Percent } \\
\text { Solids }\end{array}$ & $\begin{array}{c}\text { Mean } \\
\text { Percent } \\
\text { TOC } \\
\text { (dry wt) }\end{array}$ \\
\hline Lauritzen Channel & 6 & 26 & 25 & 42 & 49 & 1.91 \\
\hline Parr Canal & 4 & 24 & 37 & 34 & 45 & 5.19 \\
\hline
\end{tabular}




\subsubsection{Effectiveness}

The potential effectiveness of each option is evaluated by considering the degree to which it meets the following criteria: reduction in toxicity, mobility, or volume through treatment; minimization of residual risk and affordance of long-term protection; compliance with ARARs; minimization of short-term impacts; and speed in achieving protection. Alternatives providing significantly less effectiveness than other, more promising alternatives may be eliminated, and alternatives that do not adequately protect human health and the environment must be eliminated from further consideration.

\subsubsection{Implementability}

This criterion focuses on the technical feasibility and availability of the technologies each alternative would employ, and the administrative feasibility of implementing the alternative. Alternatives that are technically or administratively infeasible or that would require equipment, specialists, or facilities that are not available within a reasonable period of time may be eliminated from further consideration.

\subsubsection{Cost}

The costs of construction and any long-term costs to operate and maintain the alternatives are considered. Costs that are grossly excessive compared to the overall effectiveness of alternatives may be considered as one of several factors used to eliminate alternatives. Alternatives providing effectiveness and implementability similar to that of other alternatives by employing a similar method of treatment or engineering control, but at greater cost, may be eliminated.

\subsection{SCREENING OF REMEDIAL TECHNOLOGIES AND PROCESS OPTIONS}

Remedial technologies and process options for each general response action are presented and screened below.

\subsubsection{Institutional Controls}

Institutional controls comprise land use and deed notices or restrictions, site access control, and site monitoring (i.e., sample collection and analysis). Site monitoring can be used to determine whether remedial action objectives have been achieved, to demonstrate the effectiveness and 
permanence of containment structures, or to assess environmental transport and impact if no action is taken.

\section{Deed Notices or Restrictions}

The human health risk assessment (Section 1.7) found that past actions had reduced upland soil contaminant concentrations to acceptable levels for the site's current and expected future commercial and water-related industrial uses. The site would not be suitable for residential development without further evaluation and possibly further remediation. Although residential development is not an expected use at the site and zoning regulations would prevent the site's conversion to residential use, a deed notice or restriction would provide additional assurance that such use could not occur without further evaluation.

Effectiveness. A deed notice or restriction would provide additional assurance that only reasonable anticipated future uses allowable under current zoning and considered in the human health risk assessment would occur in the future.

Implementability. Deed restrictions or notices are easy to implement.

Cost. The cost of a deed restriction or notice is low.

Overall Evaluation. A deed restriction or notice will be included as a component of remedial alternatives.

\section{Site Access Restrictions}

Site access restrictions are fencing and posting of signs. The Levin Richmond Terminal is a private industrial facility that is fenced and has $24-\mathrm{h}$ security. The concentrations of contaminants remaining in soils at the site would not pose an unacceptable risk to trespassers. The facility and the Lauritzen Channel are also posted with signs warning that channel sediments and fish and shellfish are contaminated. These signs are in English, Spanish, Vietnamese, and Laotian.

Effectiveness. Site access restrictions and warning signs reduce the potential for human exposure, although they cannot be relied upon to be completely effective. Despite the warning signs, a person was observed fishing in the Lauritzen Channel during field work for the ecological assessment. Access restrictions and posting also only affect human behavior and do not reduce ecological impacts.

Implementability. Access restrictions are easy to implement. 
Cost. The cost of access restrictions is low.

Overall evaluation. Site access restrictions are already in place due to the industrial nature of the site and past state orders regarding contamination. Although they may reduce human exposure, they cannot accomplish the goal of protecting the envircnment. Because achieving the remedial action objectives will protect both human health and the environment, site access restrictions should not be necessary after remediation.

\section{Site Monitoring}

Site monitoring can be used to determine whether remedial action objectives have been achieved, to demonstrate the effectiveness and permanence of containment structures, or to assess environmental transport and impact if no action is taken.

Effectiveness. Site monitoring is necessary to evaluate the effectiveness of remedial actions. It will not reduce site risks.

Implementability. Site monitoring is easily implemented.

Cost. The costs of site monitoring are relatively low.

Overall Evaluation. Site monitoring will be retained as a component of remedial alternatives and the "no action" alternative.

\subsubsection{Containment}

Contaminated sediments may be isolated by capping them with clean sediment or by containing them in a CDF. Containment eliminates human and environmental exposure by isolating contaminants, but does not reduce their toxicity or volume. CDFs can be located in an upland or nearshore setting. CDF locations under consideration in this FS include the Lauritzen Channel, the Parr Canal, and the graving docks at Point Potrero. Each option for containment is evaluated below.

\section{In-Situ Capping of Marine Sediments}

In marine environments, caps are typically composed of clean sand or silt. In some cases, a geotextile fabric is placed over the contaminated sediment prior to capping to prevent mixing of the cap and underlying contaminated sediment. Placement of the capping material must be carefully controlled to ensure complete and adequate coverage, and to prevent mixing of the capping material with contaminated sediment. The technical feasibility of capping depends upon the ability of the in- 
situ sediment to support the cap, the bottom topography of the site, and the likelihood of cap erosion or disruption.

The younger bay mud is weak and highly compressible. These properties can cause the settlement and possible failure of the younger bay mud under an imposed load (Goldman 1969). The younger bay mud, which is from $1 \mathrm{ft}$ to $10 \mathrm{ft}$ thick in the Lauritzen Channel and Parr Canal, is underlain by the drier and firmer older bay mud. The older bay mud has better foundation characteristics tian the younger bay mud. The bottom of the Lauritzen Channel slopes steeply to the east from approximately $-10 \mathrm{ft}$ MLLW in the undredged portion to $-40 \mathrm{ft}$ MLLW at the Levin terminal, which would make capping difficult (see Figure 2.1). The bottom of the Parr Canal is generally level. The soft, water-bearing younger bay mud may be prone to slumping or failure, particularly in response to seismic activity. Any cap design would need to consider the engineering characteristics of the younger bay mud and older bay mud.

Pesticides are not likely to migrate through a cap in dissolved form because of their low solubility in water; therefore, the contaminants are likely to remain isolated as long as the cap is not disrupted. Caps may be eroded by currents, waves, bioturbation, or other disturbances. In inner Richmond Harbor, currents and waves generally have insufficient energy to erode sediment in the absence of other disturbances. The thickness of the cap must be sufficient to prevent mixing of the cap material with the underlying contaminated sediment by organisms that colonize the cap. Other potential disturbances include the grounding of ship hulls, propeller-wash, and slumping. The likelihood of cap disruption by ship traffic in the Lauritzen Channel is high given its current use as an active shipping terminal. The bottom of the Parr Canal is shallow and level, and it is not used by ship traffic; therefore, the likelihood of cap erosion by boats is lower, although erosion by stormwater runoff is a concern.

Effectiveness. In-situ capping has the potential to isolate the entire volume of contaminated marine sediment in the Lauritzen Channel and Parr Canal, thereby providing long-term protection. Over the short term, capping would eliminate the existing benthic communities in the affected channels, although it is expected that they would be recolonized with more diverse populations. Carefully controlled placement of the cap material would minimize the resuspension of contaminated sediment. In-situ caps have been successfully used at numerous sites, particularly in quiescent, shallow (20 $\mathrm{m}$ to $30 \mathrm{~m}$ ) water (Morton 1989). In general, existing caps have stabilized after initial reworking and consolidation of the contaminated sediment. Capping could be accomplished quickly. 
The effectiveness of a cap in the Lauritzen Channel, however, would be limited by its use for deepwater shipping. Ship, barge and tugboat scouring and grounding would ercile a cap unless shipping were prohibited as part of the remedy. The effectiveness of a cap in the Parr Canal is questionable because of its shallow depth (approximately $6 \mathrm{ft}$ ) and the presence of a large storm drain culvert at its north end. A cap would reduce the depth of the canal significantly, increasing the velocity of stormwater flow and the potential for erosion, particularly during low tides.

Implementability. In-situ capping is generally technically implementable using available equipment. Some sediments in the Lauritzen Channel might have to be leveled prior to capping. However, in-situ capping in the Lauritzen Channel would not be compatible with its existing use as a deep-water port facility. Capping would reduce the depth of channel berths and preclude maintenance dredging.

Cost. The costs for in-situ capping would be lower than the costs of other containment options.

Overall Evaluation. In-situ capping of sediment in the Lauritzen Channel sediment has been screened out as a process option because it is incompatible with its continued use as a shipping channel. In-situ capping alone of the Parr Canal has also been screened out because of its uncertain effectiveness due to the canal's shallow depth and the potential for erosion of the cap by stormwater flows. Other remedial actions that will be considered for the Parr Canal include dredging. Given the canal's heavy riprap and narrow, irregular configuration, it may be difficult to effectively dredge all contaminated sediments. Therefore, capping after dredging with small quantities of clean material that would not significantly change the canal's current bathymetry may be considered as a component of dredging. Minor capping may also be appropriate in isolated areas of the Lauritzen Channel, if dredging is determined to be impractical or ineffective.

\section{Capping Upland Soils}

The remedial action objective for upland soils is the prevention of erosion and transport to the Lauritzen Channel. A simple asphalt cap over the approximately five acre unpaved area of the site where the United Heckathorn facility was located would prevent wind and rain transport of site soils, and prevent erosion and dust generation caused by vehicles and equipment used onsite.

Effectiveness. A cap could be placed quickly and would effectively prevent erosion over the long term, given routine maintenance. A cap will also reduce rainwater infiltration. 
Implementability. Capping is readily implementable using available equipment and materials.

Cost. The cost of a cap is relatively low.

Overall Evaluation. An asphalt cap will be retained as a component of remedial alternatives to accomplish the objective of preventing erosion of upland soils.

\section{Containment in the Lauritzen Channel}

Contaminated sediments could be contained behind a rock dam or sheet pile bulkhead installed across the Lauritzen Channel or along its eastern shoreline. The most contaminated sediments are located in the northern half of the Lauritzen Channel. These sediments, which are currently behind the proposed location of the dam, would remain in place, thereby minimizing the environmental risks associated with dredging. The remaining storage capacity would be filled with dredged sediment from other areas of the site (the southern part of the Lauritzen Channel and the Parr Canal). Dredgeci sediments would be capped with clean fill and eventually paved after consolidation, creating additional terminal space. Construction of the dike would increase turbidity and create short-term environmental risks, which could be minimized by using a turbidity barrier (silt curtain) during construction. This option would require extension of the storm drain from its current position at the head of the Lauritzen Channel to the outboard side of the proposed dike, and would result in a reduction of the length of shoreline in the channel. The shoreline sheetpile wall variation of the CDF would not interfere with the storm drain or reduce the length of shoreline, but would require dredging of more contaminated sediment.

A CDF must be designed to ensure that contaminants cannot migrate out of the structure. Because pesticides tend to remain associated with fine-grained sediment, loss of contaminants in leachate or through tidal pumping and diffusion (i.e., in the dissolved phase) is not a major concern. If the integrity of the structure were maintained, then complete containment of the sediment-bound contaminants should be achieved. The older bay mud would act as a low-permeability barrier under the contaminated sediment. Results of the marine RI indicate that the older bay mud is an effective barrier to contaminant migration, and it is approximately $50 \mathrm{ft}$ thick in the Richmond area.

Effectiveness. CDFs are a standard technology used for sediment disposal, and have a proven effectiveness. Containment in the Lauritzen Channel would consolidate sediment from two channels into a single smaller area in order to eliminate exposure pathways. Lauritzen Channel disposal facilities would have sufficient capacity to contain all of the sediment requiring remediation. Long- 
term maintenance would be required. The shoreline sheetpile wall variation would probably require more maintenance than the rock dam. Short-term impacts due to dredging would be reduced relative to other options by containing some sediment in place. Adverse impacts would include loss of shoreline and open water area.

Implementability. CDFs can be constructed with readily available equipment and material. The variation which includes a dam across the northern end of the channel would eliminate shoreline of adjacent property owners, and agreements would have to be reached regarding these impacts.

Cost. The cost of containment facilities is moderate. There would be minor reductions in dredging costs since some sediment would remain in place.

Overall Evaluation. CDFs are a standard technology used for sediment remediation, and would be effective and implementable at the Lauritzen Channel. Lauritzen Channel CDFs have been retained for further consideration.

\section{Containment at the Parr Canal}

A CDF at the Parr Canal site of sufficient capacity to contain the sediment from the Lauritzen Channel would require both filling the Parr Canal and using adjacent upland space. A possible configuration is shown in Figures 3.1 and 3.2. The existing storm drain at the head of the canal would either have to be rerouted or extended approximately $900 \mathrm{ft}$.

Effectiveness. A CDF at the Parr Canal site would have long-term effectiveness similar to the Lauritzen Channel options. The dikes around all sides of the CDF would increase long-term maintenance requirements. The most contaminated sediments at the head of the Lauritzen Channel would have to be dredged, increasing short-term impacts. A longer length of shoreline would be eliminated.

Implementability. This option could be implemented using standard material and equipment.

Cost. The cost of this option would probably be higher than the Lauritzen Channel alternatives due to the need for the construction of dikes around the entire facility and the probable $900 \mathrm{ft}$ extension of the existing storm drain.

Overall Evaluation. Containment at the Parr Canal site would isolate contaminants as effectively as the containment option for the Lauritzen Channel, but it would have several additional 


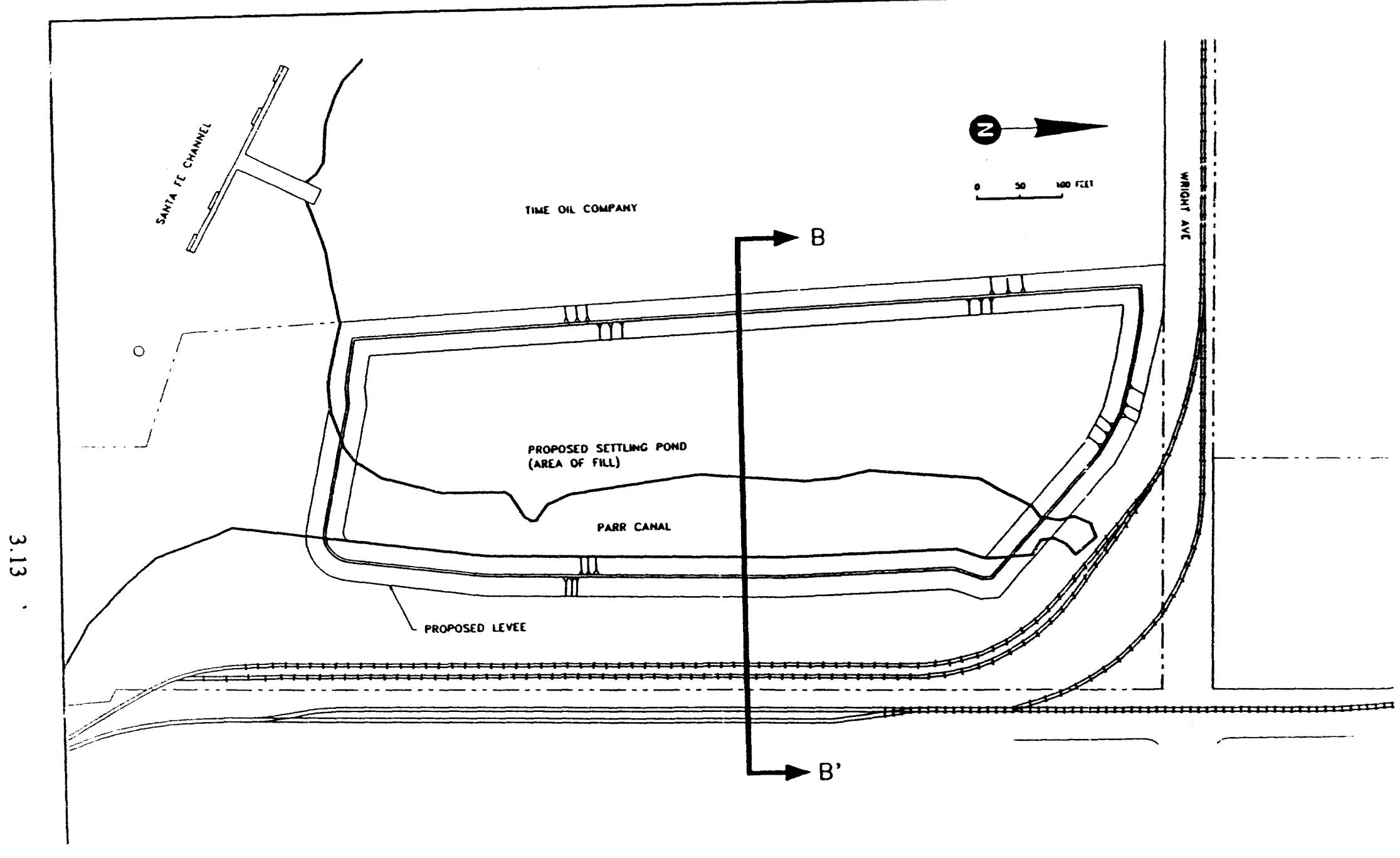

From 8/10/93 letter from Levine-Fricke to EPA.

FIGURE 3.1. Proposed Location of Confined Disposal Facility at the Parr Canal 


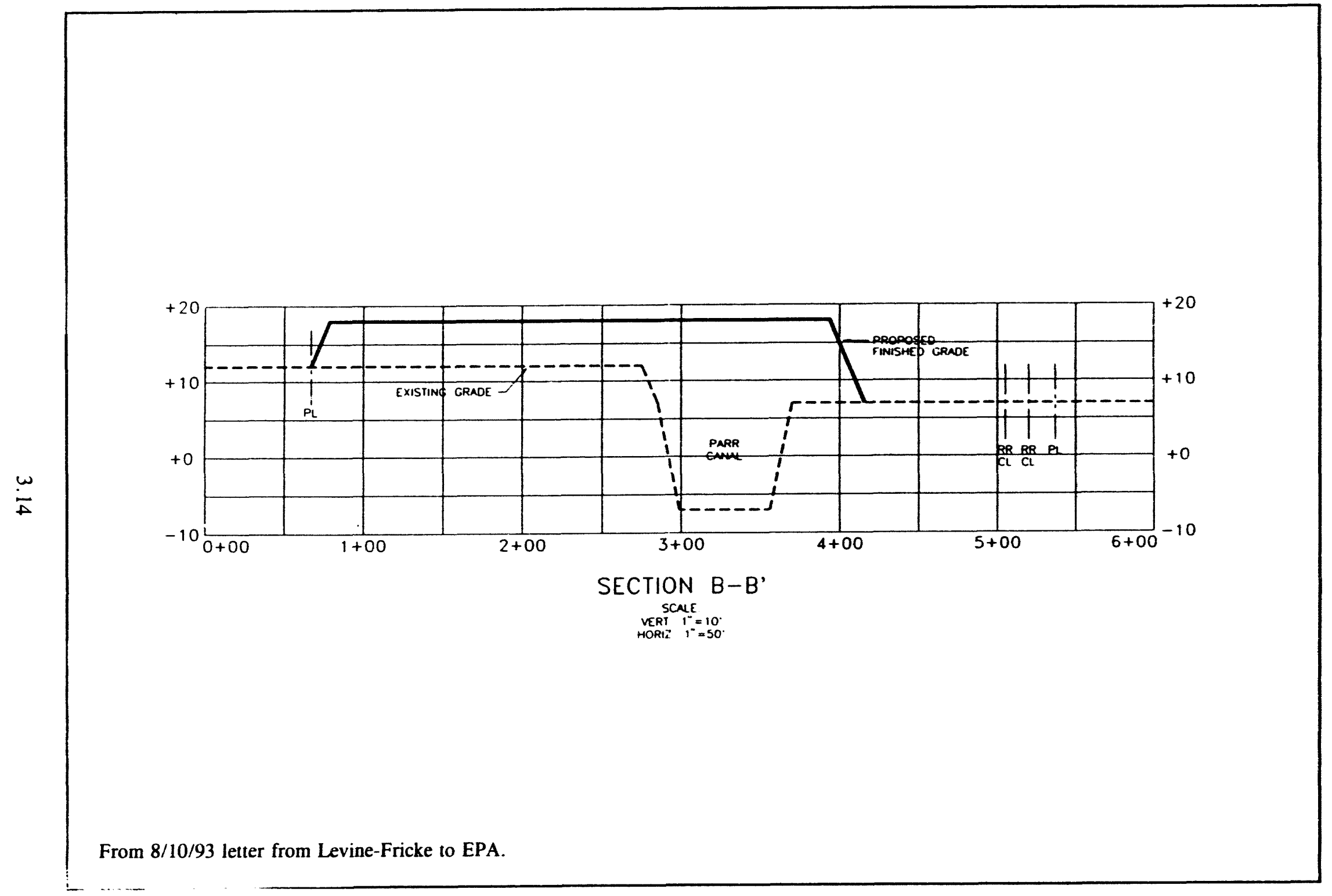

FIGURE 3.2. Cross-Section of Proposed Confined Disposal Facility at the Parr Canal 
disadvantages, including increased length of dike construction and storm drain extension, and longterm maintenance requirements. Because this alternative does not appear to offer advantages when compared to similar containment alternatives and has environmental and cost disadvantages, it will not be retained for detailed analysis.

\section{Containmeut in the Graving Docks at Point Potrero}

Any of the five drydock basins at Point Potrero could potentially be modified and used to contain contaminated sediments. The graving docks are no longer utilized for ship repair and are not large enough to accommodate modern cargo ships. The Port of Richmond has investigated the possibility of filling the docks with dredged material and constructing a new wharf. The basins are lined with concrete, and they could contain between $89,000 \mathrm{cy}$ and $500,000 \mathrm{cy}$ of sediment, depending on the number of basins filled. The watertight gates have been removed from the basins, and they are currently open to the bay. The docks would have to be inspected, repaired, and retrofitted to function as a CDF. Contaminated sediments could be dredged and transported by barge or pipeline to the graving docks, which are about 1.25 miles south of the United Heckathorn site. The sediments may require dewatering after placement, particularly if hydraulic dredging is used. Treatability testing has indicated that effluent from dewatering sediment is likely to exceed water quality criteria, and would probably require treatment if discharged to the bay. After filling, the graving docks could be capped and paved to create additional terminal space.

Effectiveness. The graving docks would be expected to provide excellent long-term containment of contaminated sediments. Short-term impacts within the Lauritzen Channel would be slightly increased due to increased dredging. Bay fill would only occur in a concrete-lined structure, rather than over bay mud.

Implementability. This option is technically implementable using standard materials and equipment. Administratively, it might be difficult to implement, due to the need for agreements between the city of Richmond, which owns the facility, and the parties implementing the remedy regarding long term liability.

Cost. The total cost of using the graving docks as a CDF would consist of the costs of preparing a basin to contain contaminated sediment, and modifying the facility to enhance port use. The total cost would be comparable to that of Lauritzen Channel CDFs. 
Overall Evaluation. The Point Potrero graving docks have a potential to effectively isolate contaminated sediments and will be retained for detailed analysis.

\subsubsection{Dredging}

Any remedial action except in-situ capping requires dredging of contaminated sediment from the Lauritzen Channel and Parr Canal. Dredging must be followed by treatment, disposal, or containment. Dredging is performed by lowering removal equipment into the water and extracting the sediment. Dredged sediments are typically loaded on a companion vessel or pumped by pipeline to shore. Dredged sediments may be transported to the disposal area by pipeline, barge, railroad, or truck.

Dredging results in short-term environmental risks from the resuspension of contaminated sediment, and the loss of existing benthic communities. Treatability testing indicated that pesticide concentrations in the water column during dredging are expected to be elevated. Short-term impacts can be minimized by the use of silt curtains to confine resuspended sediments within the dredging area. State water quality objectives are not currently achieved within the channels proposed for remediation, and would not be achieved during dredging. They would be expected to be achieved outside the dredging area, and throughout the site after remediation.

The two most common types of dredging are mechanical and hydraulic. Special purpose dredges have also been developed for the removal of highly contaminated sediment. The selection of the appropriate dredge technique depends in part upon the physical characteristics of the sediment, the contaminant level and mobility, the thickness and volume of sediment to be removed, water depth, the configuration of dredge area, site access, the presence of pilings and debris, current speeds and waves, the disposal method and distance to the disposal area, equipment availability, and compliance with ARARs. Each type of dredging technique is described and evaluated below.

\section{Mechanical Dredging}

In mechanical dredging, sediments are dislodged by the direct application of a mechanical force and then removed, typically with a clamshell bucket. The solids content of dredged sediment is similar to that of the in-situ sediment. Sediment is resuspended by the impact, penetration, and removal of the bucket, leakage from the bucket, and washing of the bucket as it passes through the water column. Suspended sediment concentrations in the vicinity of the dredge may range from 20 milligrams per liter (mg/L) to $1100 \mathrm{mg} / \mathrm{L}$ (McLellan et. al 1989). Closed clamshell buckets can 
reduce suspended sediment concentrations by $30 \%$ to $70 \%$ (Cullinane et al. 1989). In addition, a turbidity barrier can be used to reduce suspended sediment concentrations outside of the dredge area. Turbidity barriers are typically made of a permeable, fine-mesh geotextile fabric suspended from a metal framework.

Mechanical dredging is less efficient than hydraulic dredging (Zappi and Hayes 1991). It is also generally less accurate and the dredged surface may not be level, although these may not be problems at the site since remediation would be based on removal to the hard, underlying, older bay mud contact. Mechanical dredging takes longer to complete than hydraulic dredging, which may slightly increase costs. However, it may be the preferred dredging method if the disposal method requires that the sediments have a high percent solids, or if treatment of effluent from dewatering sediment proves to be difficult and expensive.

Effectiveness. Mechanical dredging can effectively remove contaminated sediments and should achieve compliance with ARARs. Mechanical dredging would produce sediment that would require little or possibly no dewatering. Risks posed by resuspended sediment would be controlled by the use of silt curtains placed across the mouths of the channels. Dredging would have the short-term impact of removing existing benthic communities, but recolonization by a more diverse population would be expected.

Implementability. Conventional clamshell equipment is readily available in San Francisco Bay. Closed clamshell buckets are not as common, but could be obtained.

Cost. The cost of dredging is low. The cost of mechanical dredging is comparable to that of hydraulic dredging. The production rate is lower, but sediment might not require dewatering.

Overall Evaluation. Mechanical dredging is effective for removing contaminated sediments, as long as suspended sediment concentrations are controlled. This method may be preferred for most disposal options because of the lower water content of dredged sediment, and will be retained as an option for sediment removal in the detailed alternatives analysis.

\section{Hydraulic Dredging}

Hydraulic dredges use centrifugal pumps to remove sediments as a liquid slurry. A mechanical cutting head is usually attached to the end of the vacuum line to break up the sediment and establish the slurry form. The slurry typically contains $80 \%$ water. Less sediment is resuspended during hydraulic dredging. Suspended sediment concentrations in the vicinity of 
conventional cutterhead dredges range from about $5 \mathrm{mg} / \mathrm{L}$ to $200 \mathrm{mg} / \mathrm{L}$, and modifications can reduce this concentration even further (Zappi and Hayes 1991). Hydraulic dredging is faster, more efficient, and easier to control than mechanical dredging. However, the slurry may require dewatering prior to disposal, and effluent treatment may be necessary. Treatability testing indicates that particulate control might not sufficiently reduce pesticide concentrations in effluent produced when dredging the most contaminated areas; carbon filtration or another treatment method might also be required.

Effectiveness. Hydraulic dredging can effectively remove contaminated sediments and should achieve compliance with ARARs. Hydraulic dredging would reduce short-term impacts associated with resuspension, although large volumes of water would be entrained with the dredged sediment. Although the speed of dredging would increase with hydraulic dredging, the overall speed of the remediation might be decreased by the need for dewatering of produced sediment. Dredging would have the short-term impact of removing existing benthic communities, but recolonization by a more diverse population would be expected.

Implementability. Conventional hydraulic dredging equipment is readily available in San Francisco Bay.

Cost. The cost of hydraulic dredging is similar to or higher than that of mechanical dredging. Hydraulic dredging is faster, but dewatering and effluent treatment could substantially increase the cost of this option.

Overall evaluation. Hydraulic dredging is an effective and easily implemented removal technology. Resuspension of sediments is minimized with this method, however; the water content of the dredged sediment is approximately $80 \%$. Dewatering and treatment may be required prior to disposal. Hydraulic dredging will be retained as an option for sediment removal in the detailed alternatives analysis.

\section{Special Purpose Dredges}

Special purpose dredges have been designed and used to excavate highly contaminated sediments. These machines are pneumatic, oozer, cleanup, matchbox, and dustpan dredges (Zappi and Hayes 1991). These dredges are intended to minimize sediment resuspension during dredging. These dredging methods are relatively new and have been tested with variable degrees of success in the U.S. and elsewhere. 
Effectiveness. These dredges can be very effective; however, the degree of success depends upon the technique used and the experience of the operator.

Implementability. Specialized equipment and experienced operators are not readily available in the United States.

Cost. These options are relatively expensive compared to mechanical or hydraulic dredging because of their limited availability.

Overall Evaluation. Although these options may be very effective, the equipment is not readily available. The long and narrow configuration of the Lauritzen and Parr Canals will easily allow the installation of a turbidity barrier; therefore, the added expense of specialized equipment may not be warranted. These options are screened from further consideration.

\subsubsection{Treatment}

Four categories of remedial technologies associated with this general response action include thermal, biological, chemical, and physical treatment. Sediment treatment may be performed in-situ or on dredged sediment. In-situ treatment minimizes the exposure of receptors during remediation; however, these technologies are limited by the need to perform the treatment uniformly throughout the sediment mass and to provide evidence of the completeness of the remediation. Generally, the effectiveness of in-situ remedial technologies has not been studied or demonstrated for marine sediments, and only ex-situ treatment options are evaluated in this FS.

In its guidance document Selecting Remediation Techniques for Contaminated Sediment (EPA 1993), EPA provides a method for screening out treatment technologies that are inappropriate for given sediment characteristics. Treatment options that have been used or proposed for contaminated soils are beginning to be evaluated for sediments. The use of these techniques on sediments would require the additional prior steps of dredging and dewatering. Construction of a temporary shoreline CDF or removal to an offsite location would probably be required prior to employing any treatment option. Possible treatment options for contaminated marine sediments are biological treatment, dechlorination, soil washing, solvent extraction, solidification, and incineration. Sediment characteristics that influence the effectiveness of these treatments are the type of contaminant, clay content, particle size, and water content. The high clay content of site sediments may impede dechlorination, soil washing, solvent extraction, incineration, and thermal desorption. The high water content may impede dechlorination, solvent extraction, incineration, and thermal 
desorption. The expected effectiveness of each method on marine sediment from the United Heckathorn site is discussed in greater detail below.

Biological treatment technologies use both aerobic and anaerobic methods that rely on microorganisms to degrade contaminants. The rate of degradation is very slow in an anaerobic environment; introduction of nutrients and oxygen into the sediment $c_{i-1}$, under the right conditions, stimulate biological activity. However, chlorinated pesticides, particularly DDT, are not readily biodegraded. The rate of degradation is generally inversely proportional to a compound's absorption affinity (EPA 1993). The absorption affinity of DDT is classified as "extreme," and is among the highest of synthetic organic chemicals. White rot fungus, which occurs on wood, is being developed for use in degrading DDT in soils, but the effect of salinity associated with marine sediments on biological treatment is unknown.

Dechlorination utilizes alkali metal and polyethylene glycol in a closed reaction vessel under a nitrogen atmosphere to alter chlorinated contaminants to less toxic forms. Additional waste streams that would also require treatment or disposal are produced by the process. It has not been demonstrated to be effective or readily implementable for treating soils containing chlorinated pesticides (Levine-Fricke 1991a). Its use on sediment would be energy-intensive, since it requires drying to $0.2 \%$ moisture and heating to $200^{\circ} \mathrm{F}$ to $300^{\circ} \mathrm{F}$. The effectiveness of dechlorination might also be impeded by the high clay content of site sediment. The costs of dechlorination range from $\$ 200$ to $\$ 500$ per cy.

Soil washing is a mechanical process where sediment is scrubbed with water to remove contaminants. Soil washing is not effective for contaminarits that strongly adsorb to sediment particles, or for sediment with a high percentage of fine particles.

The solvent extraction process involves mixing an appropriate nonpolar solvent with contaminated sediment to dissolve and remove the contaminants. The extracted solvent would require further treatment. The high clay and water content of the sediment and the extreme adsorption affinity of the site contaminants would reduce the efficiency of the process. In addition, there is little practical experience with this application for marine sediments. The cost of solvent extraction is $\$ 200$ to $\$ 600$ per cy. Additional costs would be incurred for waste stream treatment or disposal.

Solidification is a technique that mixes soil with stabilizers, such as cement, to immobilize contaminants and reduce leachability. Fine-grained particles affect the bonding of the sediment with 
the stabilizing agents. Solidification is often an appropriate technology for treating leachable metals, but does not provide a significant benefit for contaminants, such as DDT, that are already comparatively immobile and insoluble. Solidification has not been proven or accepted for treatment of contaminated sediment (EPA 1993).

Incineration has been used successfully to destroy organic contaminants in sediment. Contaminants are destroyed by combustion and thermal oxidation in an industrial kiln or furnace. Incinerators typically achieve greater than $99 \%$ destruction for organics (EPA 1993). However, the sediment characteristics described above may decrease its effectiveness. The ash and residual solids may also require additional treatment and disposal. The high water content of marine sediment increases the energy requirements of the incinerator and greatly increases the cost. Fine-grained particles (clay and silt) may pass through the system and cause particulate loading (the Lauritzen Channel sediments contain an average of $67 \%$ silt and clay). The cost of incineration after dewatering would be over $\$ 1,000$ per cy.

Thermal desorption consists of heating the contaminant matrix to $200^{\circ} \mathrm{F}$ to $1000^{\circ} \mathrm{F}$ to evaporate contaminants, which are either destroyed in a secondary incinerator, or recovered by carbon absorption. Thermal desorption creates several waste streams, some of which may require additional treatment or disposal. It is generally more effective than solvent extraction, although its effectiveness may also be impeded by high clay content. Thermal desorption is typically accomplished using mobile units, although use of these might not be possible in the area. The high water content of marine sediment would increase energy usage and costs. The cost of thermal desorption is $\$ 110$ to $\$ 450$ per cy. Additional costs would be incurred for waste stream treatment or disposal.

Effectiveness. Technically, the effectiveness of sediment treatment is uncertain, given the chemical characteristics of the COCs and the high water, salt, and clay content of the sediment. However, even if site sediment were treated to destroy the COCs, the overall effectiveness in terms of residual risk reduction would be extremely minor. The current risks associated with site contaminants are due to the sediments' presence in the aquatic environment, which permits direct exposure to marine organisms and bioaccumulation in the food chain. Any treatment option would require removal of the sediments from the aquatic environment in order to prepare them for treatment. Once the contaminants are removed from the aquatic environment, the risks associated with the concentrations of chemicals in sediments are low. After dredging and consolidation, the average 
concentration of DDT in dredged sediments from the Lauritzen Channel and Parr Canal would be approximately $30 \mathrm{mg} / \mathrm{kg}$ wet $\mathrm{wt}$, and the concentration of dieldrin would be less than $1 \mathrm{mg} / \mathrm{kg}$ wet wt (White et al. 1994). These concentrations are within EPA's acceptable carcinogenic risk range for long-term human exposure under either residential or industrial conditions. Thus, treatment after removal would not effectively reduce long-term risk. The transportation, waste generation, and processes involved in most treatment options would increase short-term risk.

Implementability. The treatment of marine sediments from the site would greatly increase the complexity of remediation. It is likely that a temporary CDF would be needed to contain and dewater dredged sediments prior to treatment, which would have the ARARs and implementability concerns discussed in Section 3.1.3.

Cost. The cost of any treatment process would be very high considering the need for the treatment process itself as well as for dewatering, transportation, energy requirements, and disposal or treatment of waste streams.

Overall evaluation. The technical feasibility of treatment is uncertain, given the site contaminants and the site sediment characteristics. Treatment would greatly increase the complexity and cost of remediation. Even if treatment were feasible, the long-term reduction in residual risk would not be significant, since the contaminant concentrations will not pose an unacceptable risk after removal from the aquatic environment. The NCP (55 FR 8846, March 8, 1990) indicates that "EPA expects to use treatment to address the principal threat posed by a site, whenever practicable" and "...to use engineering controls, such as containment, for waste that poses a relatively low long term threat or where treatment is impracticable." Therefore, treatment is screened from further consideration.

\subsubsection{Offsite Disposal}

Dredged sediment may be disposed of at an offsite location. Dredged sediment from the site would not be hazardous waste under RCRA, but might still be subject to disposal restrictions, depending on the location and type of disposal facility. If hydraulic dredging were used, dewatering of the sediment might be required prior to disposal. Dredged sediment is often disposed of in open water, in landfills, or in upland areas as part of beneficial re-use projects. Disposal at offsite locations would be subject to all applicable federal, state and local permitting requirements. 


\section{Open Water Disposal}

Ocean disposal of dredged material is administered by EPA and USACE in accordance with the Marine Protection, Research, and Sanctuaries Act of 1972. Bay disposal is administered by EPA and USACE under the Clean Water Act. Dredged material must meet federal testing guidelines to be approvable for either ocean or bay disposal. The basic requirement is freedom from toxicity.

Effectiveness. Open water disposal would not be approvable for site sediments. Sediment testing during the ecological assessment and RI indicates that sediments in the Lauritzen Channel are acutely toxic to marine organisms.

Implementability. Open water disposal is readily implementable from a technical standpoint, but administratively infeasible because the required approval would be unattainable due to the concentrations of site contaminants and associated toxicity.

Cost. The cost of open water disposal would be low.

Overall Evaluation. The residual risks posed by site contaminants are due to the contaminants' presence in the marine environment. Open water disposal of sediments dredged from the United Heckathorn site is clearly inappropriate and is screened from further consideration.

\section{$\underline{\text { Landfill Disposal }}$}

Under the CERCLA offsite policy, contaminants removed from Superfund sites can only be disposed of at land disposal facilities operating in compliance with applicable permits. Dredged material from the United Heckathorn Site contains CERCLA hazardous substances, but not RCRA hazardous wastes. Wastes would be transported to a permitted offsite disposal facility by truck or rail.

Effectiveness. Landfilling at an offsite facility would permanently isolate the contaminants of concern from the aquatic environment. The residual risks associated with site sediments would be insignificant in a permitted land disposal facility, particularly since the concentrations of contaminants in the consolidated sediments would not constitute an unacceptable risk, even if long-term human exposure were to occur.

Implementability. Landfilling is readily implementable. The sediment characteristics (i.e., chemical concentrations, and water content) must conform to the requirements of the disp 
Cost. The cost of disposal at a permitted disposal facility would be moderate, although the cost of sediment handling could be high, particularly if extensive dewatering were required. However, the costs of dewatering would be partially offset by reduced transportation and disposal costs.

Overall Evaluation. Offsite disposal at a permitted facility would isolate the site contaminants away from the marine environment, resulting in the lowest residual risk and eliminating the perpetual maintenance which would be required for a shoreline CDF. Offsite disposal can be accomplished for a reasonable cost, excluding sediment handling and transportation costs. Offsite disposal will be retained for further consideration.

\section{Upland Disposal: Beneficial Re-use}

Beneficial re-use ontions for material dredged from San Francisco Bay are being developed as part of a federal and state Long Term Management Strategy (LTMS). Beneficial re-use is intended to reduce the quantity of dredged sediment disposed of in open water. Under the LTMS, dredged material might be re-used to create or enhance wetlands, provide daily landfill cover, or restore levees, among other nonaquatic projects. The SFBRWQCB has adopted interim screening requirements which limit the concentrations of contaminants according to each of the re-use options above. Dredged material may be transported to re-use sites by barge.

Effectiveness. Most of the beneficial re-use options, except for landfill daily cover, involve use in or near the aquatic environment and would therefore be inappropriate for site sediments. Site sediments do not meet the state's screening requirements for any re-use option, including landfill daily cover.

Implementability. Although technically feasible, this option is not implementable because the pesticide concentrations in the sediment exceed the state's screening criteria.

Cost. The cost of re-use would be low.

Overall Evaluation. Beneficial re-use is not approvable due to the concentrations of contaminants in site sediments, and is screened from further consideration.

\subsubsection{Transportation}

Among the offsite disposal options screened above, only disposal at a permitted landfill has been retained for further consideration. Since dredging can produce large volumes of material very 
quickly, the speed of offsite disposal is likely to be limited by solids handling, loading, and transportation. The total in-situ volume of sediments requiring remediation is approximately $65,000 \mathrm{cy}$. For the purposes of this screening, it will be assumed that the total weight of sediments is roughly 100,000 tons. 'Transportation to a permitted facility could be accomplished by either rail or truck. These options will be discussed below.

\section{Transportation by Rail}

The Levin Richmond Terminal is accessible by rail, and rail lines run the length of the eastern shoreline of the Lauritzen Channel. Watertight rail cars are available; this would limit the need for sediment dewatering and reduce the potential for spills during transportation. Each rail car is capable of carrying 100 tons, and each train can haul roughly 80 cars. Given this capacity, staging of sediments for loading could be accomplished from a barge or on limited areas of the site. Dredging and transportation could be accomplished in approximately two months.

Effectiveness. Transportation by rail would permit rapid reduction in existing site risks with short-term risks limited to those normally associated with rail transportation. The potential for spills would be low given the use of watertight rail cars.

Implementability. Transportation by rail is readily implementable given the existing rail lines and train scale at the site. Rail transportation would require that the offsite disposal facility also be equipped with rail facilities for receiving and unloading rail cars.

Cost. The cost of transportation and disposal by rail would be low, based on estimates for the disposal of non-RCRA wastes.

Overall Evaluation. Transportation by rail offers advantages of speed of solids removal from the site, limited need for staging area, and the availability of watertight cars which should limit the need for dewatering and reduce the potential for spillage during transportation. Transportation by rail will be retained as a component of the offsite disposal alternative.

\section{Transportation by Truck}

Trucks were used to transport contaminated soil from the site during past removal actions. Sediments would have to be dewatered sufficiently to ensure that no free water could leak from trucks during transportation. Each truck can haul 20 tons, so that roughly 5000 loads would be required to transport site sediments to an offsite facility. In order to process and stage sediments for loading, a 
temporary CDF, such as those discussed in Section 3.1.3, would probably be required. Site remediation would probably take two years.

Effectiveness. Transportation by truck would require a much longer period to remove contaminated sediments from the site than transportation by rail. The short-term risks associated with the increased solids handling requirements and the volume of truck traffic would be higher than those associated with rail transport.

Implementability. Transportation of marine sediments from the site by truck would greatly increase the complexity of remediation. It is likely that a temporary CDF would be needed to contain and dewater dredged sediments prior to treatment, which would have the ARARs and implementability concerns discussed in Section 3.1.3.

Cost. The costs of transportation by truck would be much higher than the cost by rail due to both the inherent cost of the mode of transportation, and the additional costs related to a much longer project period, the increased need for sediment handling, and the probable need for construction of a temporary CDF.

Overall Evaluation. Transportation by truck has gross disadvantages compared to transportation by rail and will not be retained for further consideration.

\subsection{SUMMARY}

The results of remedial technology and option screening are summarized in Table 3.2. The process options that were retained through the screening process are the following:

- institutional controls

- capping upland soils

- containment in the Lauritzen Channel

- containment in the Point Potrero graving docks

- mechanical or hydraulic dredging

- disposal at a permitted offsite facility

- transportation by rail.

These process options are combined into remedial alternatives for the site. Remedial alternatives are presented and evaluated in Section 4.0. 
TABLE 3.2. Initial Screening of Process Options for Marine Sediment

\begin{tabular}{|c|c|c|c|c|c|}
\hline $\begin{array}{l}\text { GENERAL } \\
\text { RESPONSE } \\
\text { ACTION }\end{array}$ & TECHNOLOGY & $\begin{array}{l}\text { PROCESS } \\
\text { OPTION }\end{array}$ & DESCRIPTION & $\begin{array}{l}\text { SCREENING } \\
\text { COMMENTS }\end{array}$ & $\begin{array}{c}\text { SCREENED FROM } \\
\text { FURTHER } \\
\text { CONSIDERATION }\end{array}$ \\
\hline NO ACTION & None & None & No remedial actions. & $\begin{array}{l}\text { Detailed evaluation required by } \\
\text { NCP. }\end{array}$ & No \\
\hline \multirow[t]{4}{*}{$\begin{array}{l}\text { INSTITUTIONAL } \\
\text { CONTROLS }\end{array}$} & $\begin{array}{l}\text { Deed Notices or } \\
\text { Restrictions }\end{array}$ & & $\begin{array}{l}\text { A restriction or notice } \\
\text { indicating that remediation } \\
\text { was based on current } \\
\text { commercial/industrial land } \\
\text { use. }\end{array}$ & $\begin{array}{l}\text { Would provide additional } \\
\text { assurance that current land use } \\
\text { would not change without } \\
\text { further study and possible } \\
\text { remediation. }\end{array}$ & No \\
\hline & Access Restrictions & Warning signs & Post signs. & $\begin{array}{l}\text { Already posted. Signs would } \\
\text { remain until health risks were } \\
\text { acceptable. }\end{array}$ & No \\
\hline & & Fences & & $\begin{array}{l}\text { Private property already fenced. } \\
\text { Onsite health risks already } \\
\text { acceptable. }\end{array}$ & Yes \\
\hline & Monitoring & $\begin{array}{l}\text { Sample collection } \\
\text { and analysis }\end{array}$ & $\begin{array}{l}\text { Perform water and tissue } \\
\text { sampling and analysis to } \\
\text { assess conditions and } \\
\text { monitor contaminants. }\end{array}$ & $\begin{array}{l}\text { Applicable for assessing } \\
\text { effectiveness of remedy. Not a } \\
\text { remedy itself. }\end{array}$ & No \\
\hline
\end{tabular}


TABLE 3.2. (contd)

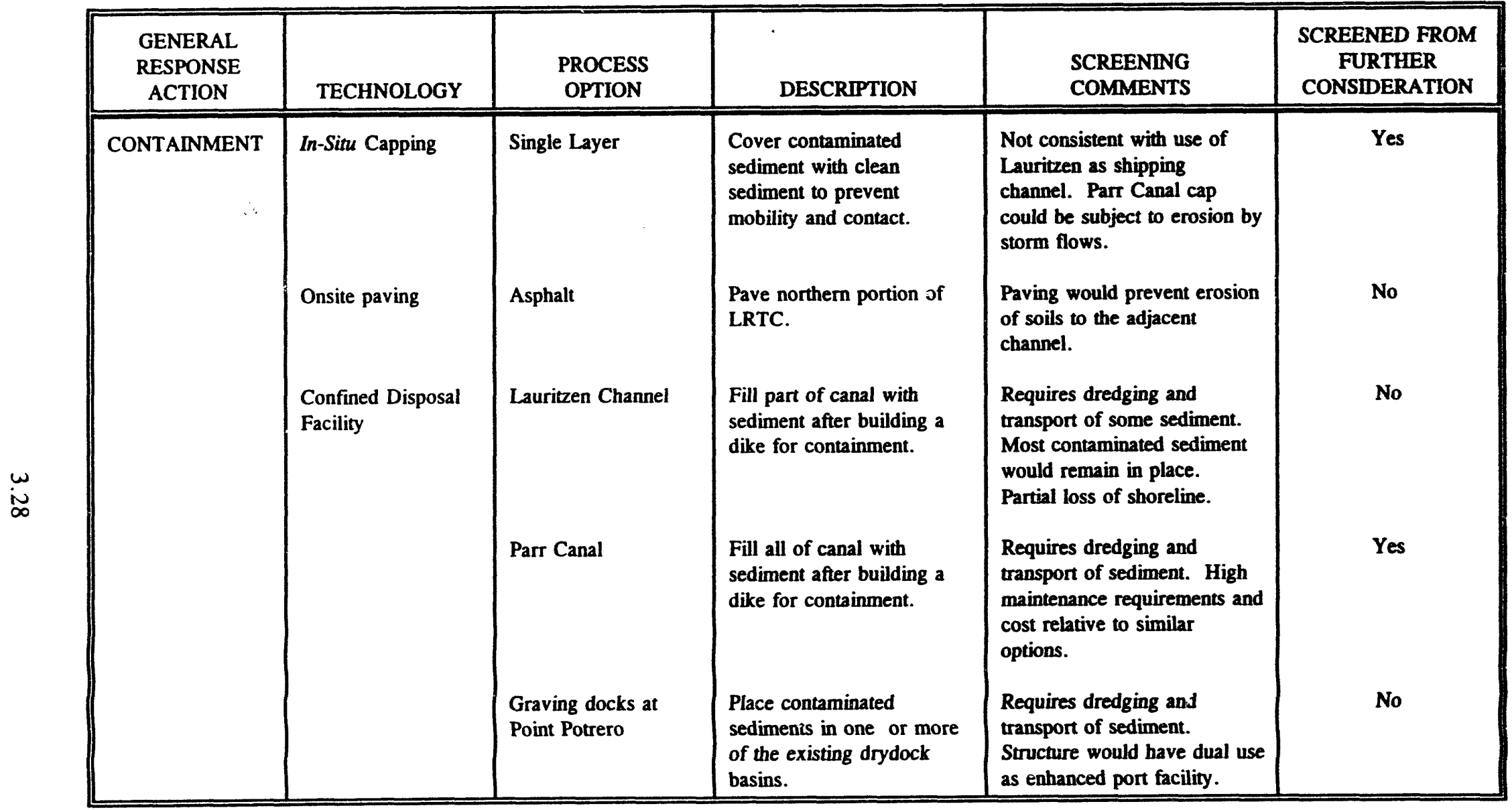


TABLE 3.2. (contd)

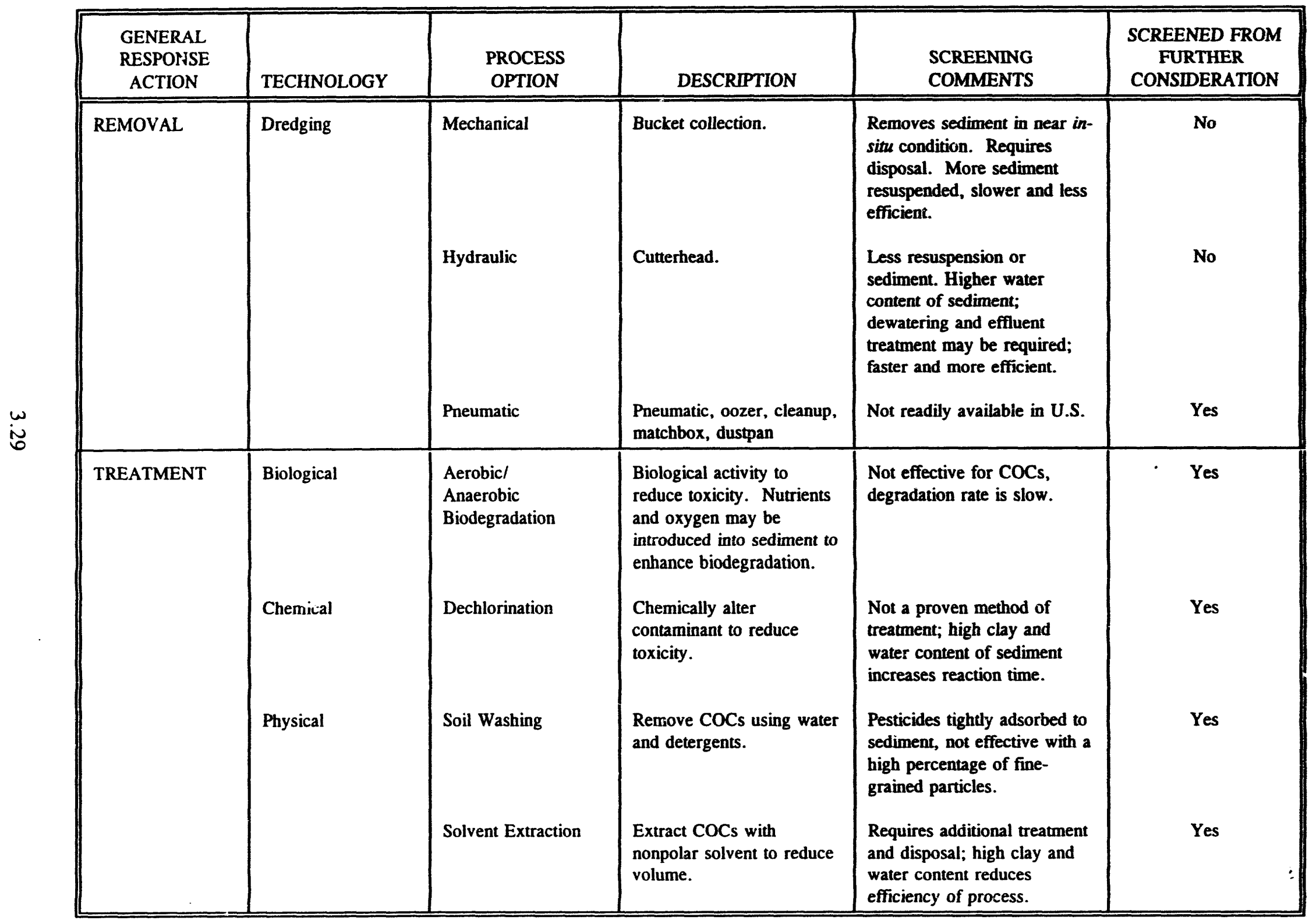


TABLE 3.2. (contd)

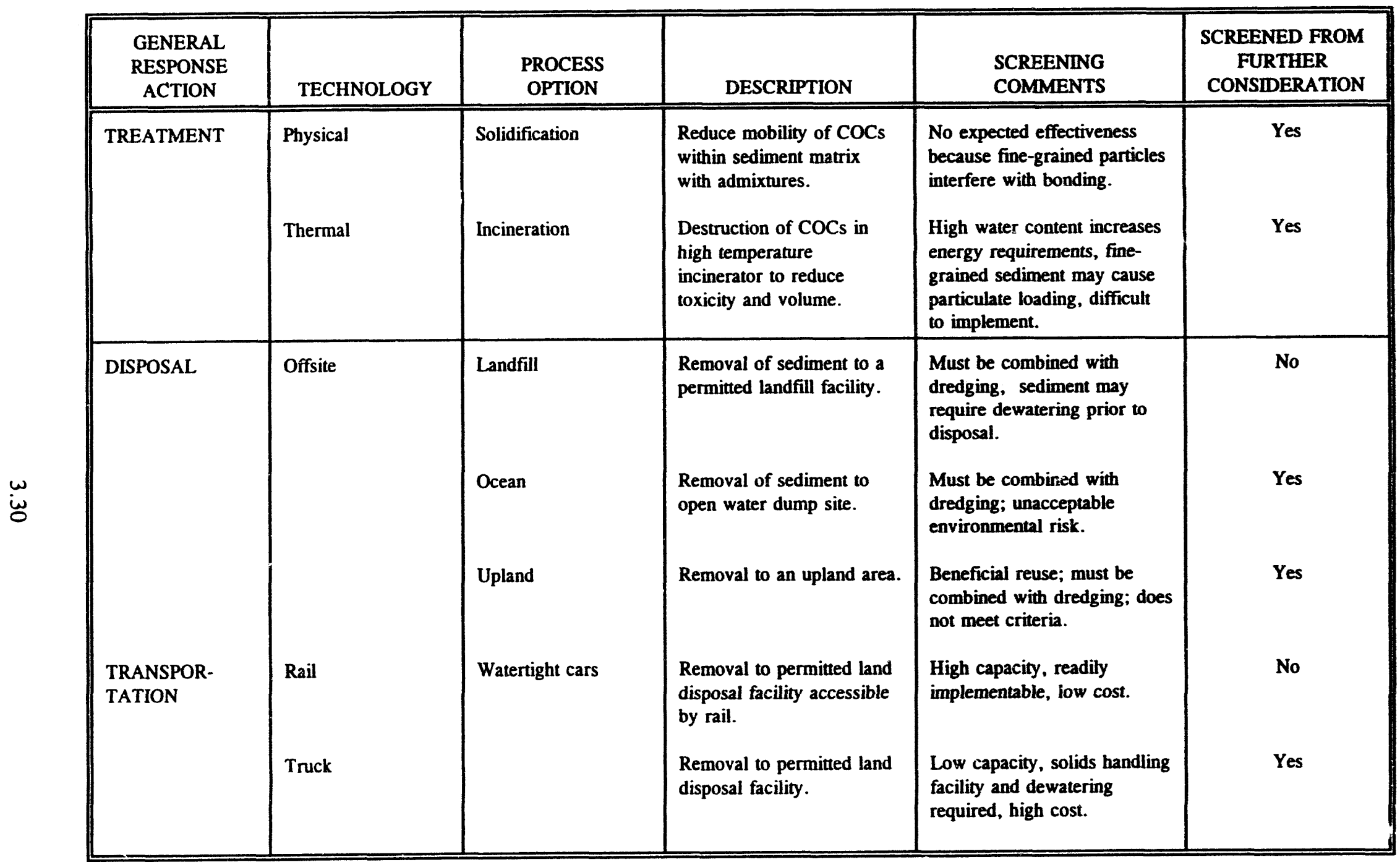



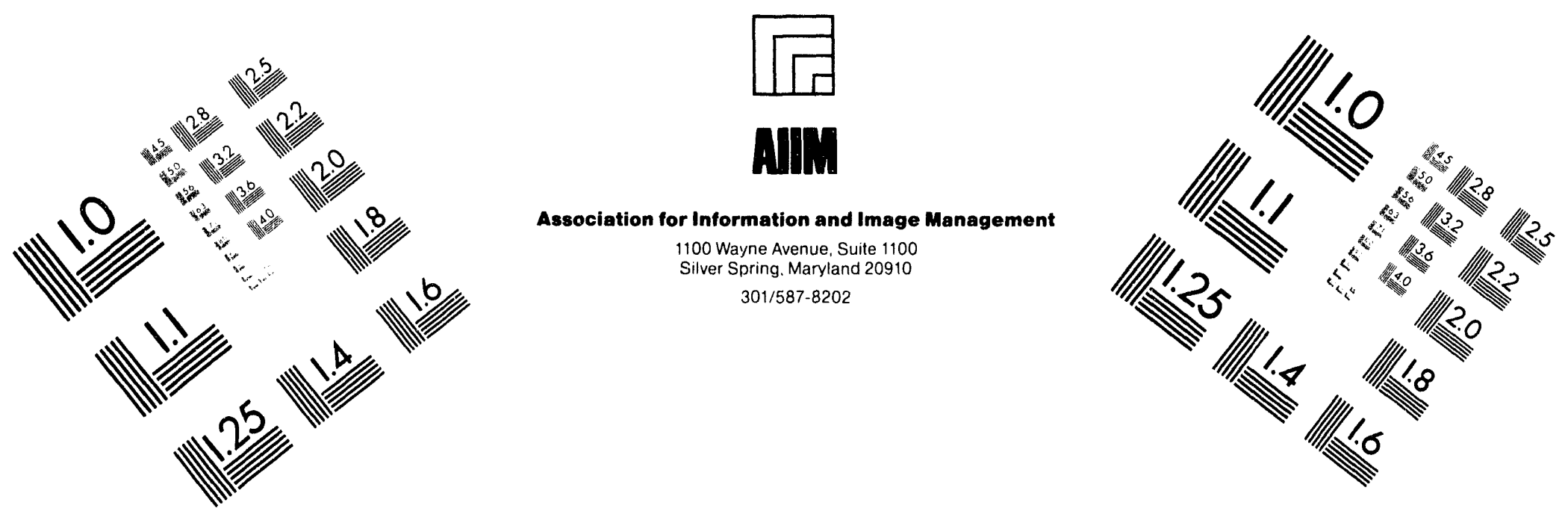

\section{Centimeter}

$\begin{array}{llllllllllllllll}1 & 2 & 3 & 4 & 5 & 6 & 7 & 8 & 9 & 10 & 11 & 12 & 13 & 14 & 15 & \mathrm{~mm}\end{array}$

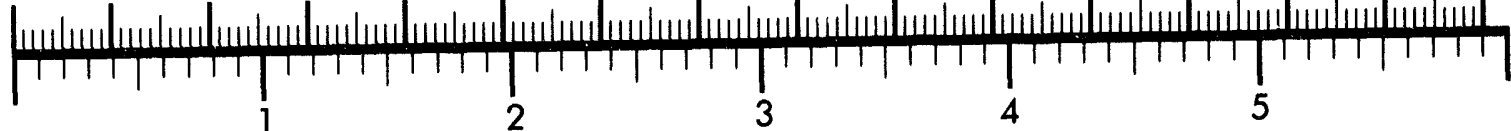
Inches
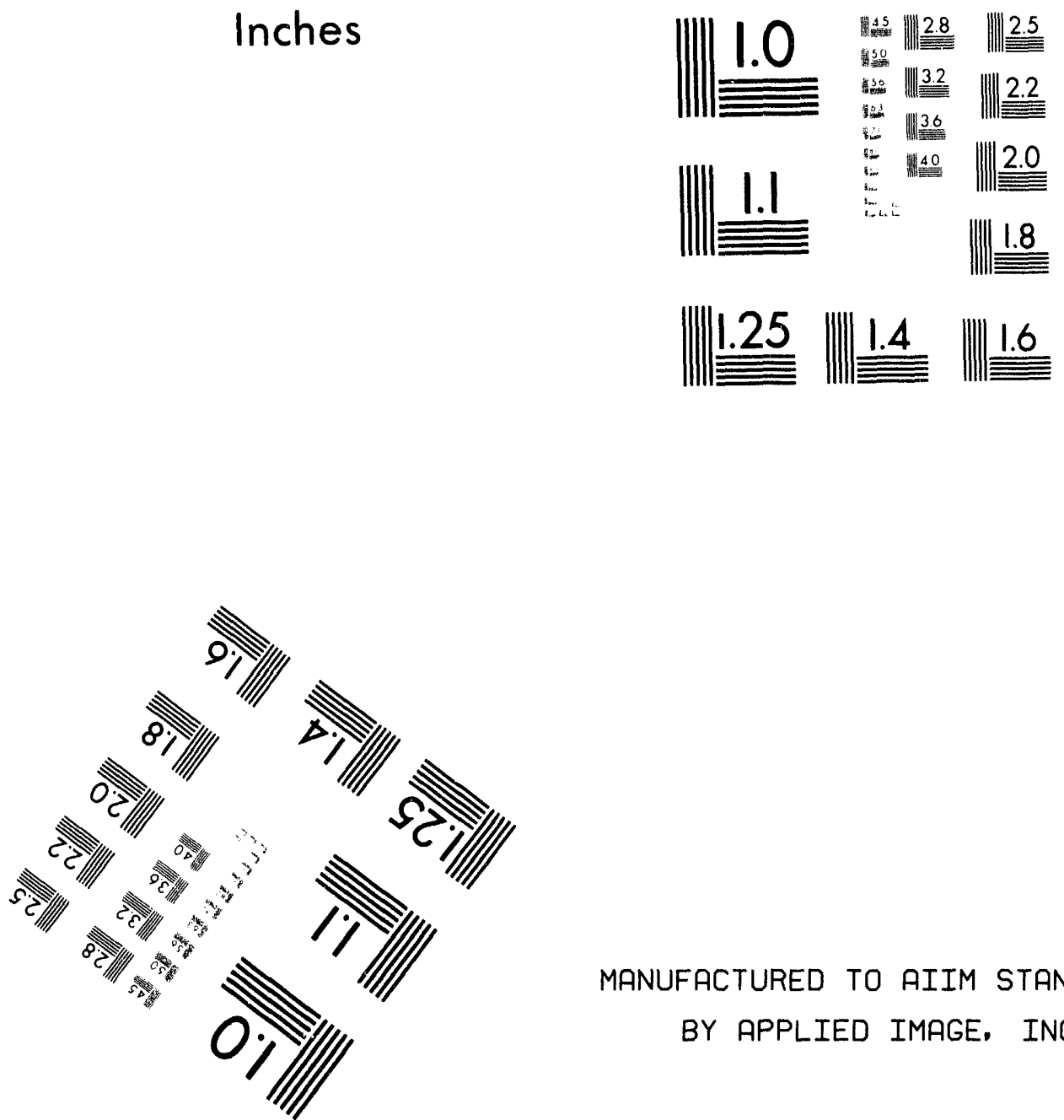

MANUFACTURED TO AIIM STANDARDS

BY APPLIED IMAGE, INC.

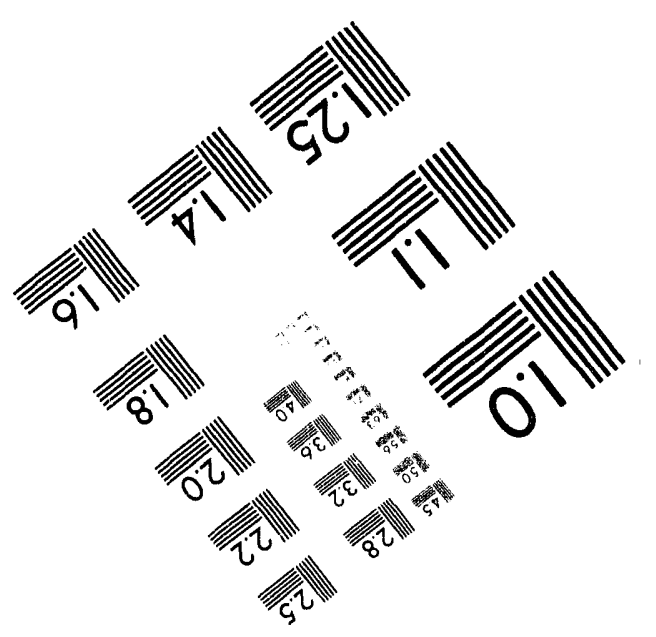



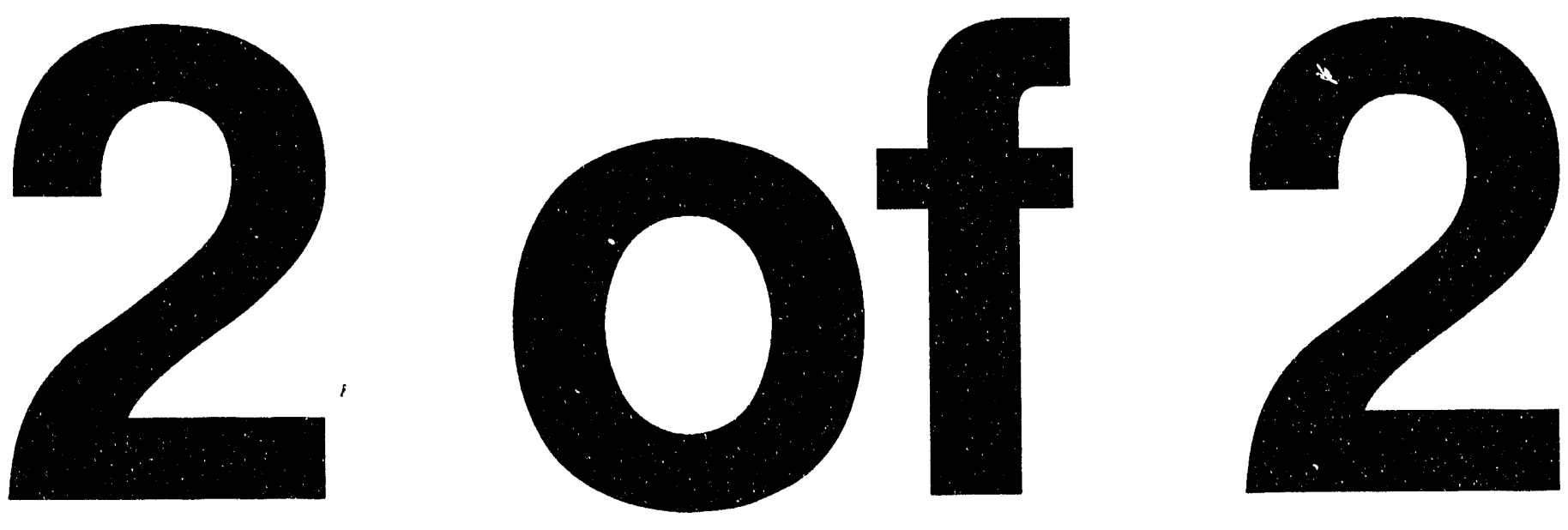


\subsection{DETAILED EVALUATION OF REMEDIAL ALTERNATIVES}

In this section, process options that were retained after the screening process in Section 3.0 are combined into alternatives that will meet the remedial action goals for the United Heckathorn site. Several alternatives have been developed to provide a range of options and sufficient information to adequately compare alternatives.

The environmental media requiring remediation in order to meet the goals defined in Section 2.2 are marine sediments in the Lauritzen Channel and Parr Canal, and upland soils on the northern half of the Levin Richmond Terminal, in the area of the former United Heckathorn facility. The action alternatives presented below all include dredging of contaminated sediments and paving of upland soils. The principal difference among these alternatives is in the location chosen for disposal of dredged sediments. In addition, the no action alternative has been retained as a baseline for comparison with the other alternatives. The four alternatives are summarized below:

Alternative 1: no action

Alternative 2: confined disposal of marine sediment in the Port of Richmond's Point Potrero graving docks, and paving of upland areas

Alternative 3: confined disposal of marine sediment in the Lauritzen Channel, and paving of upland areas

Alternative 4: offsite disposal of marine sediment by rail, and paving of upland areas.

With the exception of "no action," all of the alternatives have been developed to meet the remedial action goals. In addition to the components listed above, each action alternative includes environmental monitoring to evaluate the effectiveness of the remedy, and institutional measures to limit future site uses to those considered in the human health risk assessment.

\subsection{EVALUATION CRITERIA}

EPA has developed nine evaluation criteria to serve as the basis for selection of remedial actions at Superfund sites (EPA 1988). These criteria fall into three categories: threshold, primary balancing, and modifying, as described below. 
Threshold criteria are factors that an alternative must meet in order to be eligible for selection. The two threshold criteria are as follows:

- overall protection of human health and the environment

- compliance with ARARs.

There are five primary balancing criteria that are used to evaluate those alternatives that meet the threshold criteria. The balancing criteria are as follows:

- long-term effectiveness and permanence

- reduction of toxicity, mobility, or volume through treatment

- $\quad$ short-term effectiveness

- implementability

- cost.

Finally, there are two modifying criteria, as follows:

- $\quad$ state acceptance

- community acceptance.

The assessment of the modifying criteria is generally not complete until after state and public comments on the proposed plan are received. The threshold and primary balancing criteria are described in greater detail below.

\subsubsection{Overall Protection of Human Health and the Environment}

The assessment of overall protection of human health and the environment draws upon the evaluation of the other criteria, particularly long-term and short-term effectiveness and compliance with ARARs. The assessment focuses on whether a specific alternative achieves adequate protection and describes how the site risks posed through the exposure pathways addressed in the RI/FS are eliminated, reduced, or controlled through treatment, engineering, or institutional controls.

\subsubsection{Compliance with ARARs}

This criterion is used to determine whether an alternative will comply with the federal and state ARARs that were identified in Section 2.1. The detailed analysis for each alternative 
summarizes which requirements are applicable or relevant and appropriate, and describes how the alternative meets the requirements.

\subsubsection{Long-Term Effectiveness and Permanence}

The long-term effectiveness criterion addresses the ability of an alternative to maintain reliable protection of human health and the environment over time once the remedial action objectives have been met. This assessment evaluates the magnitude of the risk posed by residual waste, and addresses the adequacy and reliability of controls used to manage residual wastes, as well as risks posed should the remedial action need replacement.

\subsubsection{Reduction of Toxicity, Mobility, or Volume through Treatment}

The 1986 Superfund amendments emphasize a preference for selecting remedial actions that employ treatment technologies that permanently and significantly reduce toxicity, mobility, or volume of the hazardous substances as their principal element. The NCP (55 FR 8846, March 8, 1990) indicates that "EPA expects to use treatment to address the principal threat posed by a site, whenever practicable" and "...to use engineering controls, such as containment, for waste that poses a relatively low long term threat or where treatment is impracticable."

When the site was listed on the NPL in 1990, extremely high levels of pesticides were present in site soils. All known high-level deposits, which presented imminent threats, were addressed by removal actions between 1990 and 1993. The remaining concentrations of pesticides are much lower, and, as discussed in the screening of process options, are not amenable to treatment. The action alternatives analyzed in this FS meet the NCP expectation for engineering controls rather than treatment for large volumes of relatively low-level wastes.

\subsubsection{Short-Term Effectiveness}

Short-term effectiveness refers to control of adverse impacts on human health and the environment posed during the construction and implementation of an alternative until cleanup goals are achieved. This criterion addresses risks to the community, workers, and the environment during remediation and the length of time until protection is achieved.

\subsubsection{Implementability}

The implementability criterion refers to the technical and administrative feasibility of implementing a given remedial alternative. Potential technical difficulties, ease of implementation, 
and the ability to monitor the effectiveness of a given remedy should be assessed. In addition, the feasibility of implementing a technology from an administrative standpoint must be determined, and the availability of various goods and services should be considered.

\subsubsection{Cost}

The cost criterion refers to the initial capital cost to design, purchase, construct, and implement the remedial alternative, as well as the cost of operating and maintaining the alternative. The cost estimates were developed from information obtained from vendors, as well as from previous reports (JWD 1994, Levine-Fricke 1991a). The cost estimates provided in the FS are expected to have an accuracy of $+50 \%$ to $-30 \%$, and are prepared using data available from the RI.

\subsection{COMMON ELEMENTS}

Components that are common to two or more of the alternatives are discussed here to avoid redundancy in the discussion of individual alternatives.

\subsubsection{Dredging}

Alternatives 2 through 4 would involve dredging of the younger bay mud from the Lauritzen Channel and Parr Canal. The total volume of these sediments is estimated to be $65,000 \mathrm{cy}$, although if Alternative 3 were selected, some of the most contaminated sediments would remain in place in the Lauritzen Channel within a CDF. In areas to be dredged, all soft sediments down to the hard older bay mud contact would be removed. In limited areas, dredging may be impractical or of limited effectiveness in removing all contaminated sediments because of obstructions such as riprap. In those areas, minor capping, which would not significantly alter the existing bathymetry, might also be used after dredging, if determined to be necessary during the remedial design or remedial action phases.

Silt curtains would be erected across the mouths of the channels prior to dredging to prevent transport of sediment disturbed by the dredging process out of the excavation area. Dredged material would likely be stockpiled on a barge or on land to facilitate loading and/or transportation. Excess water, if any, produced during dredging and initial handling would be returned to the dredging area inside the silt curtains. However, control measures, such as physical separation or filtration, would be implemented to prevent or minimize the runoff or return of sediment back to the excavation areas. The surface water ARARs for the concentrations of COCs are not currently achieved, and would not 
be expected to be achieved in the Lauritzen Channel and Parr Canal during the remediation. The surface water ARARs are remedial action goals that are expected to be achieved after the dredging is complete. In Alternatives 2 and 3, the dredged material would be placed in shoreline facilities, where it would consolidate over a period of years. Any effluent produced from dewatering in these facilities would meet applicable standards prior to discharge to the bay or to a sanitary sewer.

Two sunken barges, one small tank, and other debris (see Figure 1.3) would have to be removed from the Lauritzen Channel prior to dredging under Alternatives 2 through 4 . In one of the configurations of Alternative 3, a CDF would be constructed in the northern end of the channel, allowing one barge and the small tank to remain in place. Samples of sediment taken by EPA divers from inside the barge and tank indicated that they are not sources of contamination.

\subsubsection{Monitoring}

The remedial action goals at the site are as follows: 1) to remove or contain sediments and upland soils in order to achieve ARARs for surface water quality in San Francisco Bay; and 2) to reduce contaminant levels in marine organisms. In order to determine the effectiveness of the remedial action, a post-remedial monitoring program would be required. Monitoring would be expected to occur annually for at least five years or until it was demonstrated that the remediation goals had been achieved, and could continue at longer intervals (i.e., once every five years) for an additional period of time, if contaminants were left in-place or confined onsite. The monitoring program would also be implemented as part of the no action alternative.

The post-remedial monitoring program would include surface water and biological monitoring components. Periodic collection and analysis of surface water samples would determine compliance with EPA ambient water quality criteria, which are ARARs. Bioaccumulation could be monitored through the periodic deployment and subsequent collection and analysis of mussels, as is done in the State Mussel Watch program. Mussels provide the most consistent, readily obtainable biological data. These data can be compared to the historic State Mussel Watch bioaccumulation database for Richmond Harbor to confirm reductions in tissue residues. Sampling locations to confirm the effectiveness of the remedy would be in the Lauritzen, Santa Fe and Richmond Inner Harbor Channels. Additional sampling might be required based on the remedy selected. For example, if confined disposal at the Port of Richmond's graving docks were selected, an additional monitoring station would be established outside the facility. 


\subsubsection{Paving of Upland Area}

The results of the human health risk assessment (Section 1.7) indicate that the removal actions performed at the site between 1990 and 1993 reduced contaminant concentrations in upland soils to levels that are acceptable for current and expected future commercial or industrial uses. Nevertheless, roughly 95,000 tons of soils over a large area of the site exceed the much lower remedial action goal for marine sediments. Therefore, a remediation goal of erosion prevention was established for upland soils in Section 2.2. The northern half of the Levin Richmond Terminal, which is where the United Heckathorn facility was located and where concentrations exceed $1 \mathrm{mg} / \mathrm{kg}$ DDT, is currently unpaved. Each of the action alternatives includes paving this area with asphalt. The area of the upland asphalt cap is shown in Figure 4.1. The cost of capping this area was estimated in the FS performed by Levine-Fricke (1991a). The estimate of $\$ 400,000$ includes a $20 \%$ contingency. This cost is included in the estimates generated for each remedial alternative except no action.

\subsubsection{Institutional Controls}

The human health risk assessment concluded that the concentrations of COCs in upland soils at the Levin Richmond Terminal had been reduced to acceptable levels for current and expected future industrial uses. This is consistent with the San Francisco Bay Plan under which the area is zoned for port priority or water-related industrial use. In order to provide an additional measure of assurance that the site could not be converted to other use without further study and possibly further remediation, a deed restriction or notice on the property will be included as part of Alternatives 2 through 4 .

The Lauritzen Channel is currently posted with signs warning fishermen that fish and shellfish may be contaminated with DDT and other pesticides. These signs will remain in place until postremedial monitoring confirms that concentrations of the COCs have been reduced to acceptable levels.

\subsection{EVALUATION OF ALTERNATIVES}

In this section, each alternative is described and evaluated in terms of the criteria discussed in Section 4.1. 


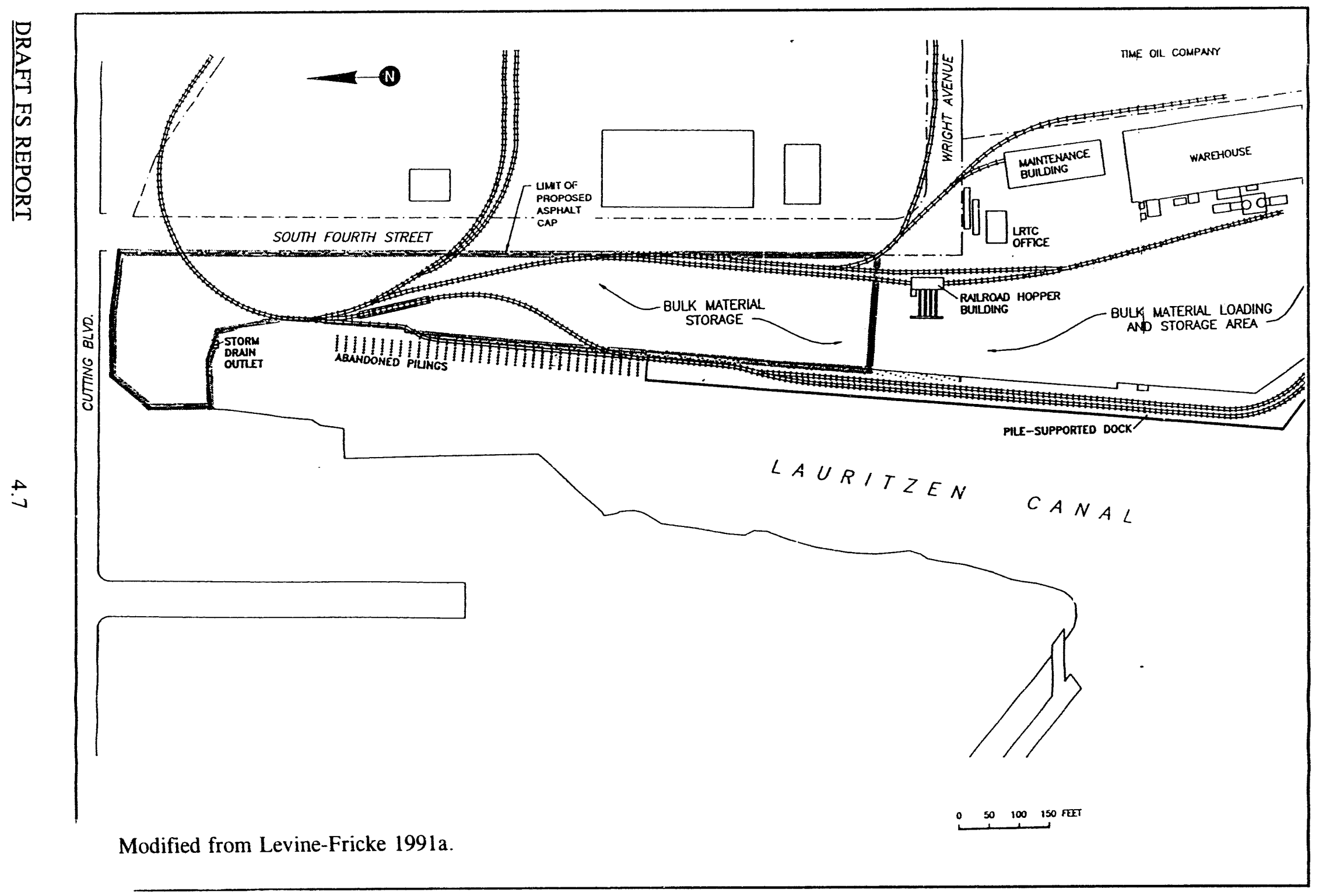

FIGURE 4.1. Limit of Proposed Asphalt Cap for Upland Soils 


\subsubsection{Alternative 1: No Action with Monitoring \\ Description}

The NCP requires the analysis of no action as an alternative (40 CFR 300.430[e][6]). Under no action, no further remediation would be conducted at the site, although the monitoring program would still be performed to evaluate the effects of the remaining contamination. The existing institutional controls would remain in place.

\section{Evaluation}

The no action alternative does not meet either of the two threshold criteria described below. Because the threshold criteria are not met, this alternative is not eligible for selection.

Overall Protection of Human Health and the Environment. The no action alternative is not protective of human health or the environment. Although discharges from United Heckathorn ended 30 yrs ago, marine sediments in the Lauritzen Channel are currently acutely toxic to benthic organisms. These conditions would be expected to persist for an indefinite period, given the extremely slow degradation of the COCs, and contamination would continue to spread into the Santa Fe and Inner Harbor channels. Fish and shellfish in the area would continue to bioaccumulate high levels of pesticides. Fish and shellfish-eating birds, including the brown pelican, an endangered species, would continue to be threatened by consumption of contaminated organisms, even at very low consumption rates in contaminated areas. Finally, fish and shellfish in the Lauritzen Channel would continue to present unacceptable health risks for human consumers. The risks associated with the contaminants may decrease over a long period as the contaminants are either buried by new sediments or dispersed by resuspension due to propeller-wash and currents.

Compliance with ARARs. The no action alternative would not result in compliance with EPA ambient water quality criteria. These remedial action goals are currently violated in the Lauritzen and Santa Fe Channels.

\subsubsection{Alternative 2: Dredging with Containment at the Point Potrero Graving Docks}

\section{Description}

The major components of this alternative are dredging approximately $65,000 \mathrm{cy}$ of contaminated sediment from the Lauritzen Channel and Parr Canal, and disposing of the sediment in a CDF constructed at the Port of Richmond's graving docks. The graving docks are located at Point Potrero, at the southern end of the Richmond Inner Harbor Channel, approximately one mile from the 
location of the former United Heckathorn facility (see Figure 1.2). A sediment containment facility constructed at the graving docks could be determined to be "onsite" under the definition of the NCP, which includes all locations within the areal extent of contamination and all suitable areas in very close proximity necessary for implementation of the response action (40 CFR 300.5).

Graving docks are concrete box structures used to drydock ships. The Point Potrero graving docks were built during World War II and, due to their relatively small size, are obsolete for modern vessels. The Port of Richmond suggested that the graving docks be analyzed as a potential disposal site for contaminated sediments because they have the capacity to effectively contain very large volumes. Depending on the configuration and number of basins used, the facility could contain between $89,000 \mathrm{cy}$ and 500,000 cy of sediment. The facility would not be simply a disposal site, but would be constructed so that it would be suitable for use as a marine shipping terminal. Use of the graving docks would not be offered by the Port of Richmond for disposal alone. The Port has analyzed a number of alternative configurations that would accommodate varying volumes of dredged material and provide the Port an additional berth or pier of at least $600 \mathrm{ft}$. The Port's cost estimates for each of the various configurations are based on the costs of preparing the basins to receive dredged material and the costs of enhancing the facility for Port use.

The configuration chosen for analysis in this FS is shown in Figures 4.2 and 4.3. It is the lowest cost configuration that would provide sufficient volume to contain sediments dredged from the Lauritzen Channel and Parr Canal. The alternative would entail filling Basin 1 with approximately 65,000 cy of sediment dredged from the Lauritzen Channel and Parr Canal and 24,000 cy of additional material to produce a total of 89,000 cy (Figure 4.3 shows all of the basins filled with sediment; however, only Basin 1 would be filled under this alternative). Prior to receiving sediment, Basin 1 would be inspected and repaired if necessary, and then sealed with a concrete bulkhead. Wick drains would be installed for dewatering. The pier between Basins 2 and 3 would be removed, and Basin 3 would be lengthened from $500 \mathrm{ft}$ to $750 \mathrm{ft}$, creating a new berth for large ships.

Dredged sediment would be barged to the drydock and deposited by mechanical means in order to minimize entrainment of water. It is estimated that consolidation of the sediment within the basin would take a minimum of four years. If hydraulic dredging were used, consolidation would probably take longer. The average concentration of DDT in the sediment would be $30 \mathrm{mg} / \mathrm{kg}$ wet wt. 


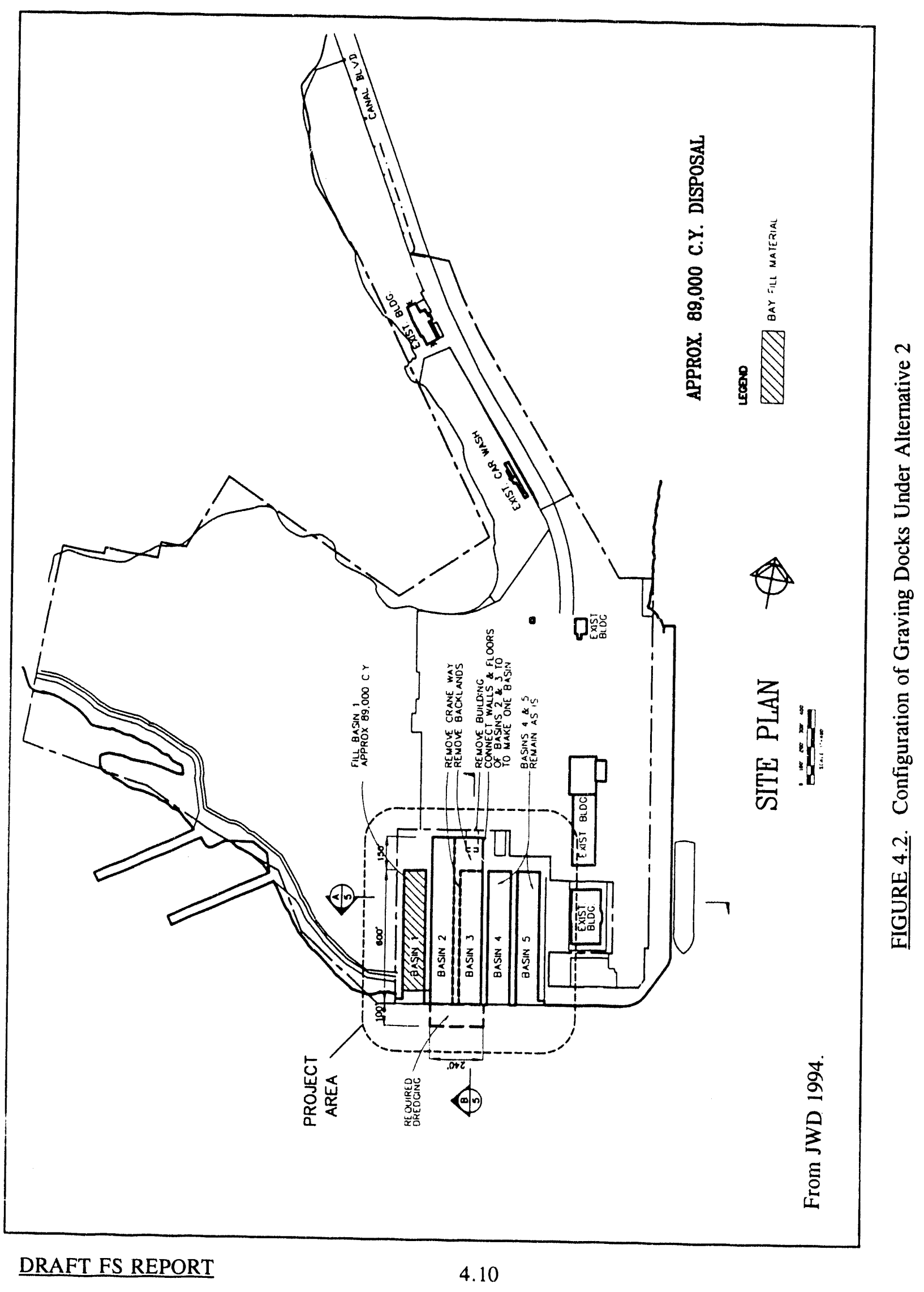




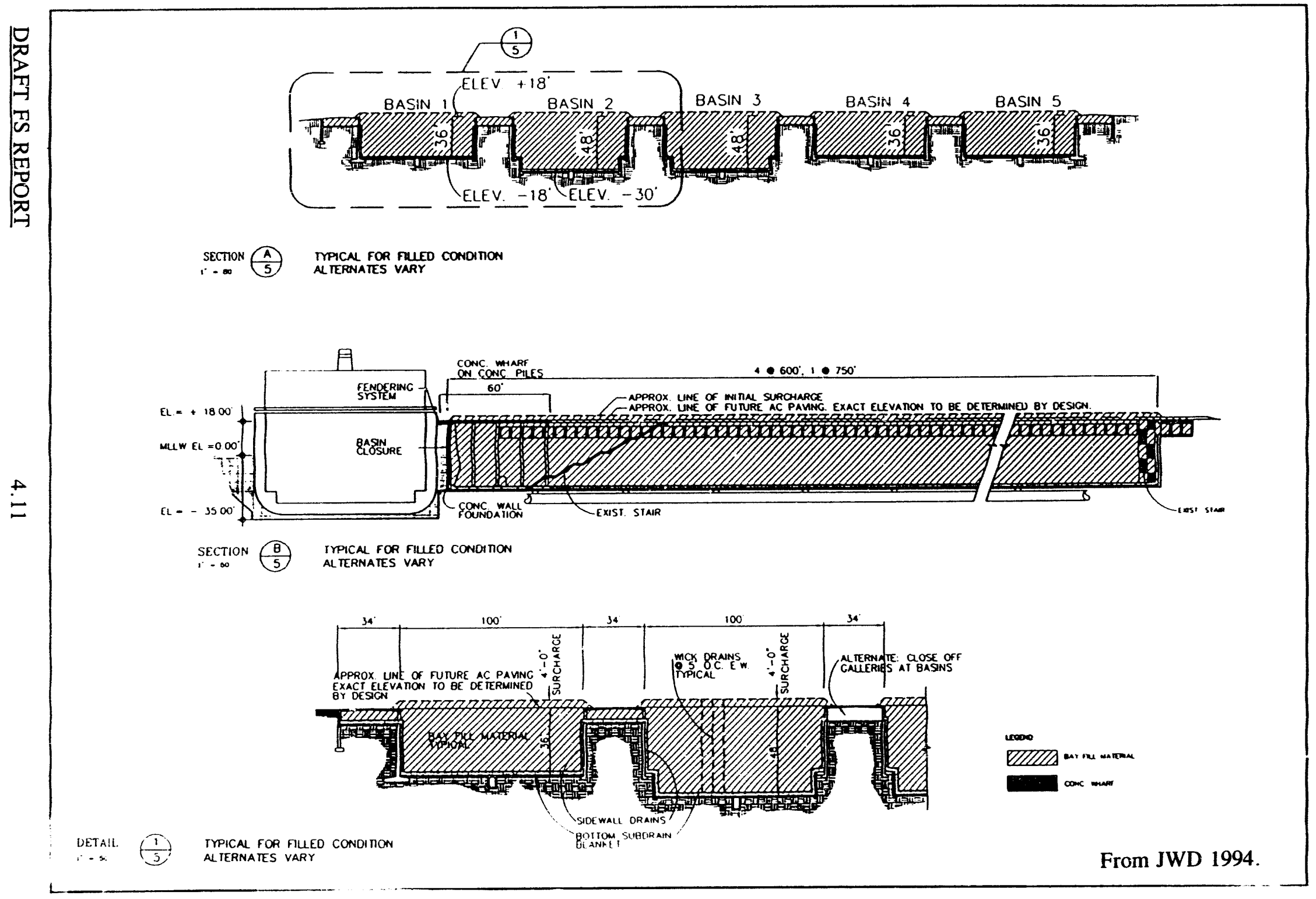

FIGURE 4.3. Cross-Section of Graving Docks Under Alternative 2 
Based on the results of the treatability testing performed during the marine RI, it is expected that treatment by filtration and carbon adsorption would be required before effluent produced by dewatering could be discharged from the basin to the bay. Although a Waste Discharge Permit would not be required under CERCLA, substantive requirements would have to be achieved, including toxicity limits and compliance with numeric water quality objectives. A possible alternative would be to discharge effluent to a sanitary sewer under permit from the local agency. Discharges to the sewer system would be "offsite" and require permitting.

In addition to the actions described above, this alternative would include the post-remedial monitoring program described in Section 4.2.2, removal of the sunken barges and other debris from the Lauritzeri Chranel, asphalt paving of the northern half of the Levin Richmond Terminal, and institutional controls as described in Section 4.2.4.

\section{Evaluation}

This alternative would be expected to meet the remedial action goals defined in Scction 2.2 and provide effective long-term protection of human health and the environment. It is unclear, however, whether it would comply with ARARs related to bay fill unless an upland alternative were unavailable. Dredging would cause short-term impacts within the excavation areas. This alternative would require agreements among a number of government and private parties regarding long-term liability and operations and maintenance, limiting its implementability.

Overall Protection of Human Health and the Environment. This alternative would meet the remedial action goals by removing contaminated sediments from the Lauritzen Channel and Parr Canal. Concentrations of the COCs in surface waters and marine organisms would be expected to drop to acceptable levels after implementation of the remedy. Short-term impacts would be confined to the currently highly contaminated areas that would be dredged.

Concrete vaults have been used elsewhere in the world for containment of contaminated sediments, and the Point Potrero facility would be expected to provide effective long-term protection of human health and the environment.

Compliance with ARARs. This alternative is expected to achieve compliance with the surface water quality criteria, which are ARARs. Two areas of concern, however, are compliance with ARARs related to filling in the bay and water of the United States, and facility requirements of the state's Hazardous Waste Control Law (HWCL). 
Although the graving docks are artificial structures that were excavated from fast land, they have been open to the bay for at least the past decade, and are part of the bay under BCDC policy. Generally, filling in the bay for disposal would be inconsistent with the San Francisco Bay Plan, and therefore also the CZMA, unless there were no upland disposal alternatives available, or it were necessary for environmental protection. Filling is also prohibited under the Clean Water Act unless there is no practicable alternative. Therefore, if the sole purpose of the graving dock facility were waste disposal, it would probably not comply with ARARs or be eligible for selection unless there were no practicable or available alternative. The Port of Richmond's graving dock plan, however, has another purpose, which is the creation of additional port capacity. This use is consistent with the Clean Water Act and the Bay Plan, and has the general support of BCDC staff. Therefore, this alternative is consistent with the CZMA and related ARARs because it accomplishes the purpose of enhancing port facilities.

The concentration of DDT in sediments consolidated in the graving docks would be approximately $30 \mathrm{mg} / \mathrm{kg}$ wet wt, which exceeds the state's TTLC of $1 \mathrm{mg} / \mathrm{kg}$. Since disposal in the graving docks would constitute onsite consolidation for the purposes of CERCLA, state hazardous wastes would not be generated, and the facility would not be permitted as a hazardous waste disposal facility. Nevertheless, some of the requirements of the state's HWCL relating to facility construction and management would still be relevant and appropriate.

Generally, facilities containing state hazardous wastes are required to have liners, leachate collection systems, and groundwater monitoring programs in order to protect groundwater. These requirements are not appropriate in this case because the facility would be a watertight concrete vault which would be expected to outperform any typical liner system. In addition, given the hydrophobic nature of the COCs, the absence of potable shallow groundwater adjacent to the bay, and the fact that the facility was constructed over bedrock and consolidated clay, further measures relative to groundwater protection are not appropriate. However, a long-term monitoring program would be established outside the docks to confirm that there were no impact to surface water.

After consolidation of the sediments, the facility would be capped with a structure sufficient to support port uses. This cap would be sufficient to meet the relevant and appropriate requirements of the HWCL, particularly because the concentration of contaminants beneath the cap would be well within the range of acceptability for long-term industrial exposure. 
Long-Term Effectiveness and Permanence. This alternative would be expected to be effective in containing contaminated sediments over a long period. The residual risks associated with this alternative are low. The concentrations of poilutarits $\vdots$. the consolidated sediments would be well within the range of acceptability if industrial COCs ever were to occur. However, perpetual maintenance of the structure would be necessary to ensure that the sediments were never released to the marine environment. The long-term effectiveness and permanence of this remedy would be confirmed through environmental monitoring.

Reduction in Toxicity, Mobility, and Volume through Treatment. This alternative does not employ treatment. It does, however, meet the expectation of the NCP for containment of high volumes of waste that have relatively low contaminant concentrations. Based on the process screening conducted in Section 3.0, treatment of the COCs in site sediments would not be practicable.

Short-Term Effectiveness. This alternative would pose no short-term risks to the community during implementation. The dredged sediments would be wet, so there would be no dust generation or wind-borne dispersion. The short-term risks to workers are primarily those inherent to construction, dredging, and solids handling. The mean concentrations of COCs in the sediments are well within the range of acceptability for long-term industrial exposure. The parties conducting the remediation would be required to develop a site health and safety plan for workers.

Dredging in the Lauritzen Channel and Parr Canal would have short-term environmental impacts. The dredging process would resuspend sediments within the excavation area. Silt curtains would be placed across the mouths of the channels prior to dredging to prevent the transport of contaminated sediment outside the excavation area. State water quality objectives for the protection of marine life are not currently achieved in the channels proposed for dredging, and would not be achieved during the remediation. Dredging the channels down to the older bay mud contact would result in the removal of the existing benthic communities from the channels. However, the existing sediment is toxic to some benthic organisms, and it is expected that the channels would be recolonized with a more diverse population.

This alternative would be expected to achieve protection within a relatively short time frame. JWD (1994) estimated that the design and permitting phase would take approximately one year. Construction of the modifications to the graving docks would take approximately one year. Dredging and placement of the contaminated sediment in the modified graving docks would take less than six 
months. Consolidation of the fill could take 3 to 10 years, depending on how aggressively the sediment is dewatered.

Implementability. This alternative is technically implementable. Concrete vaults have been used to contain contaminated sediments at other locations, and the technologies required to uiredge the channels and construct the facility are known and readily available.

Administratively, the feasibility of this alternative is limited. A complex multi-party agreement would have to be reached between the City of Richmond, which owns and operates the property, and the parties performing the remedy in order to define potential liabilities associated with permanent disposition of contaminated sediments containing hazardous substances exceeding state hazardous waste levels at an operating port facility.

Cost. A detailed cost summary for this alternative is provided in the appendix. Capital costs include the following elements: dredging of younger bay mud from the Lauritzen Channel and Parr Canal, including the salvage and disposal of debris in the Lauritzen Channel; design, preparation, and filling of the graving docks at Point Potrero, including dewatering; treatment of effluent; sample collection and analysis to confirm the effectiveness of dredging; and paving of the upland area. The cost of the modification of the Point Potrero graving docks is taken from the January 1994 report prepared by JWD Consultants for the Port of Richmond. This estimate includes roughly $\$ 700,000$ to prepare Basin 1 and close it after filling and roughly $\$ 1.8$ million to remove the pier between Basins 2 and 3 and to lengthen Basin 3 to produce a $750-\mathrm{ft}$ berth. Annual overhead and maintenance costs are evaluation and repair of the graving docks, operation and maintenance of an effluent treatment system for dewatering sediment, and post-remediation monitoring. The total estimated cost for this alternative is $\$ 5.6$ million. This estimate does not include the costs, which could be substantial, of obtaining an agreement among various parties regarding the use of the facility and future liability. In addition, state and federal agencies have indicated that they might seek mitigation to compensate for the fill associated with this alternative. The costs of mitigation would also significantly increase the total cost of this alternative.

\subsubsection{Alternative 3: Dredging with Containment at Lauritzen Canal}

\section{Description}

The major components of this alternative would be dredging between 47,000 cy and 52,000 cy of contaminated sediment from the Lauritzen Channel and Parr Canal, and depositing it in 
a CDF constructed within the Lauritzen Channel. Two variations of CDFs were analyzed for this alternative based on alternatives developed by Levine-Fricke (1991a). The first is shown in Figures 4.4 through 4.6 , and consists of a steel sheetpile wall approximately $1300 \mathrm{ft}$ long constructed along the eastern shoreline of the channel. The sheetpile wall would be tied to anchors placed in the soil at the Levin Richmond Terminal. This configuration does not interfere with either the storm drain at the northern end of the channel, or with properties across the channel from Levin.

The second variation of a CDF in the Lauritzen is shown in Figures 4.7 and 4.8. It would consist of a rock dam across the northern end of the Lauritzen Channel. Advantages of this configuration are that it would minimize the dredging of the most contaminated sediments in the channel; the barge, tank, and debris in the northern end of the channel could remain in place; it would require less maintenance than a steel sheetpile wall; and it would be less costly to construct.

Dredged sediment could be deposited in the CDF by mechanical means, or by hydraulic dredging. Consolidation of the sediment within the basin would take several years. The average concentraticn of DDT in the sediment would be $30 \mathrm{mg} / \mathrm{kg}$ wet wt. Based on the results of the treatability testing performed during the marine RI, it is expected that treatment by filtration and carbon adsorption would be required before effluent produced by dewatering could be discharged from the basin to the bay. Although under CERCLA a Waste Discharge Permit need not be obtained, substantive requirements would have to be achieved, including toxicity limits and compliance with numeric water quality objectives. A possible alternative would be to discharge effluent to a sanitary sewer under permit from the local agency. Discharges to the sewer system in this case would be "offsite" and require permitting.

In addition to the actions described above, this alternative would include the post-remedial monitoring program described in Section 4.2.2, asphalt paving of the northern half of the Levin Richmond Terminal, removal of at least one sunken barge from the Lauritzen Channel, and institutional controls as described in Section 4.2.4.

\section{Evaluation}

This alternative would be expected to meet the remedial action goals defined in Section 2.2 and provide effective long-term protection of human health and the environment. It is unclear, however, whether it would comply with ARARs related to bay fill unless an upland alternative were unavailable. This alternative would require the least amount of dredging, which would minimize 


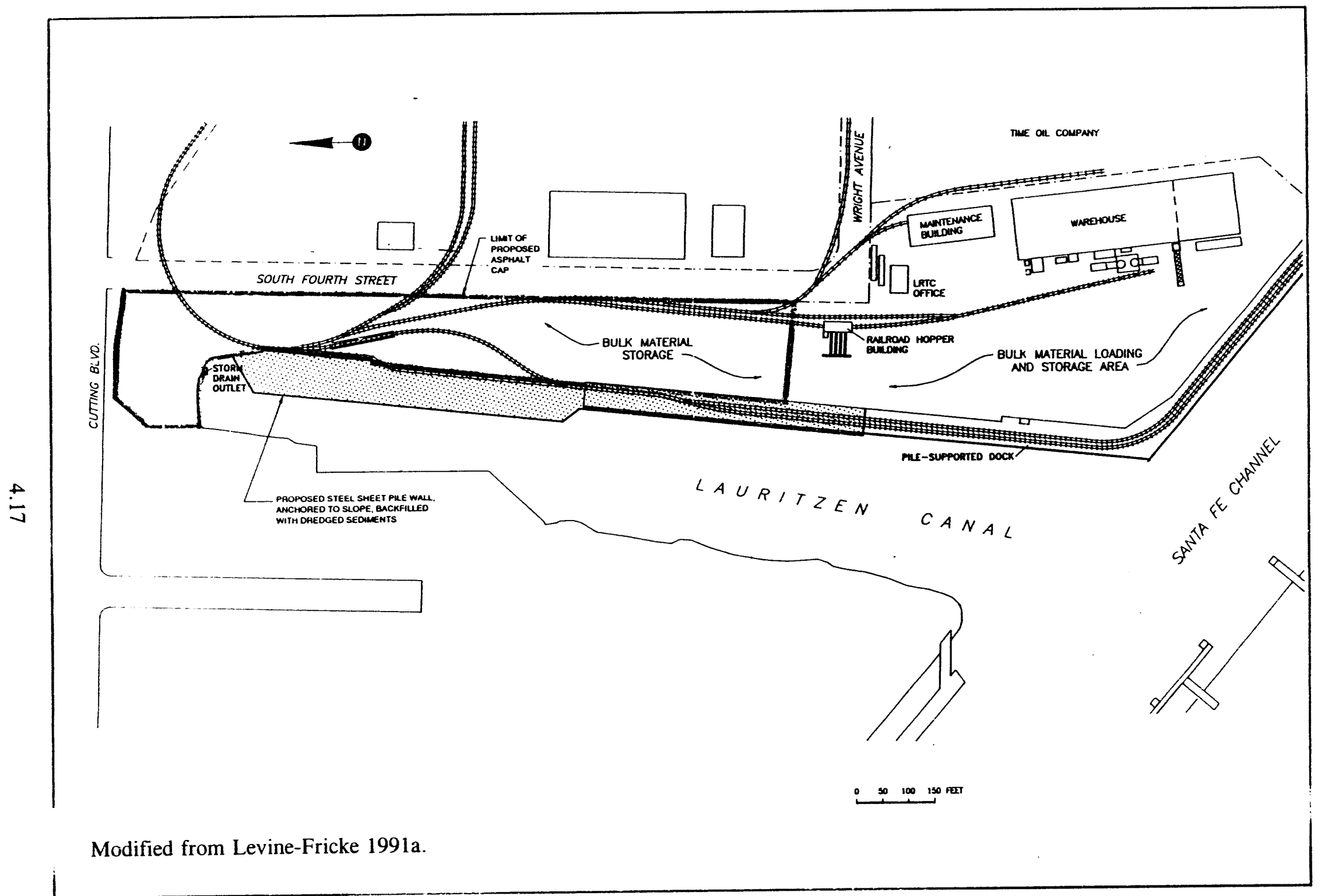

FIGURE 4.4. Configuration of Sheetpile Wall, Alternative 3 


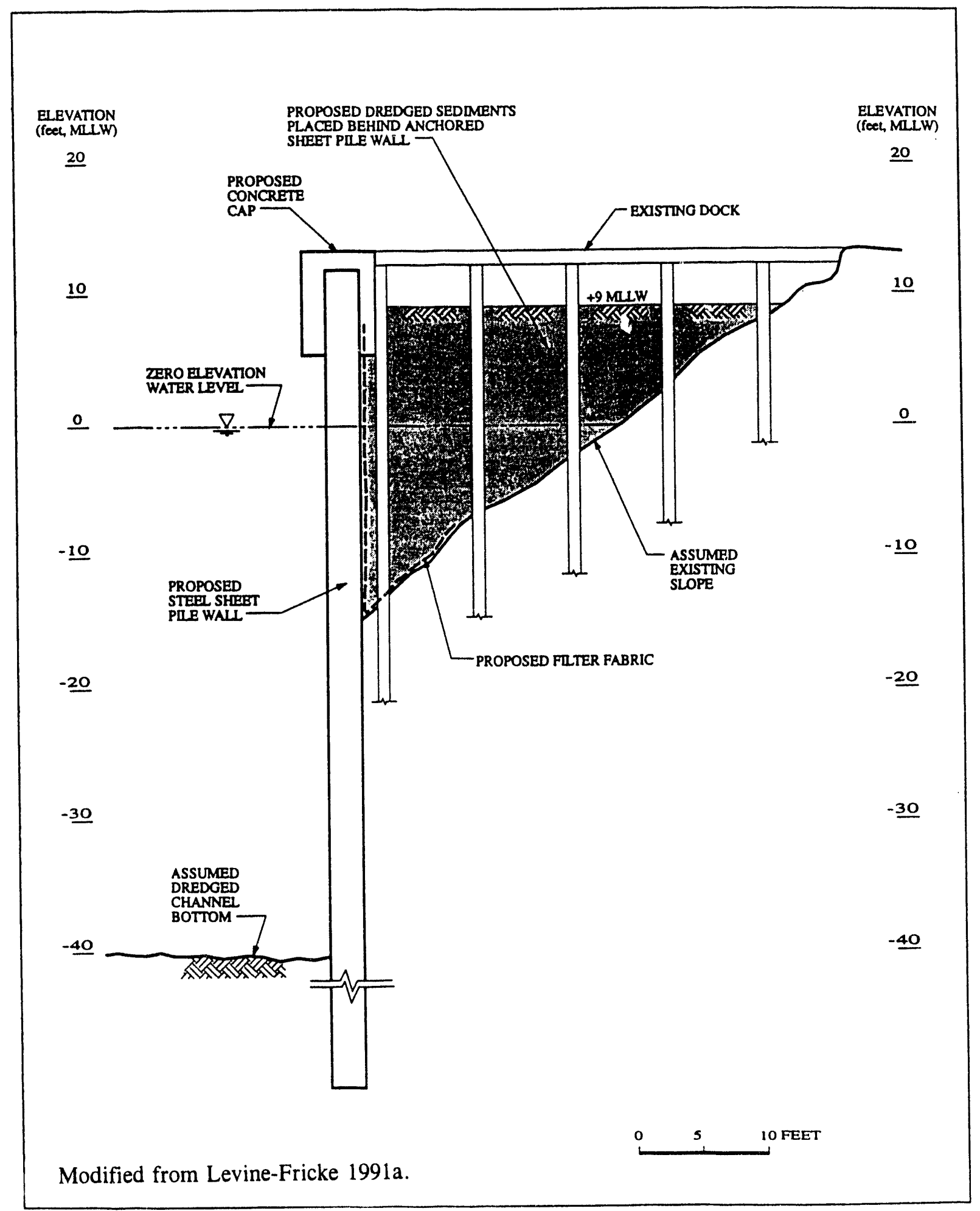

FIGURE 4.5. Cross-Section of the East Bank of the Lauritzen Channel, Alternative 3 


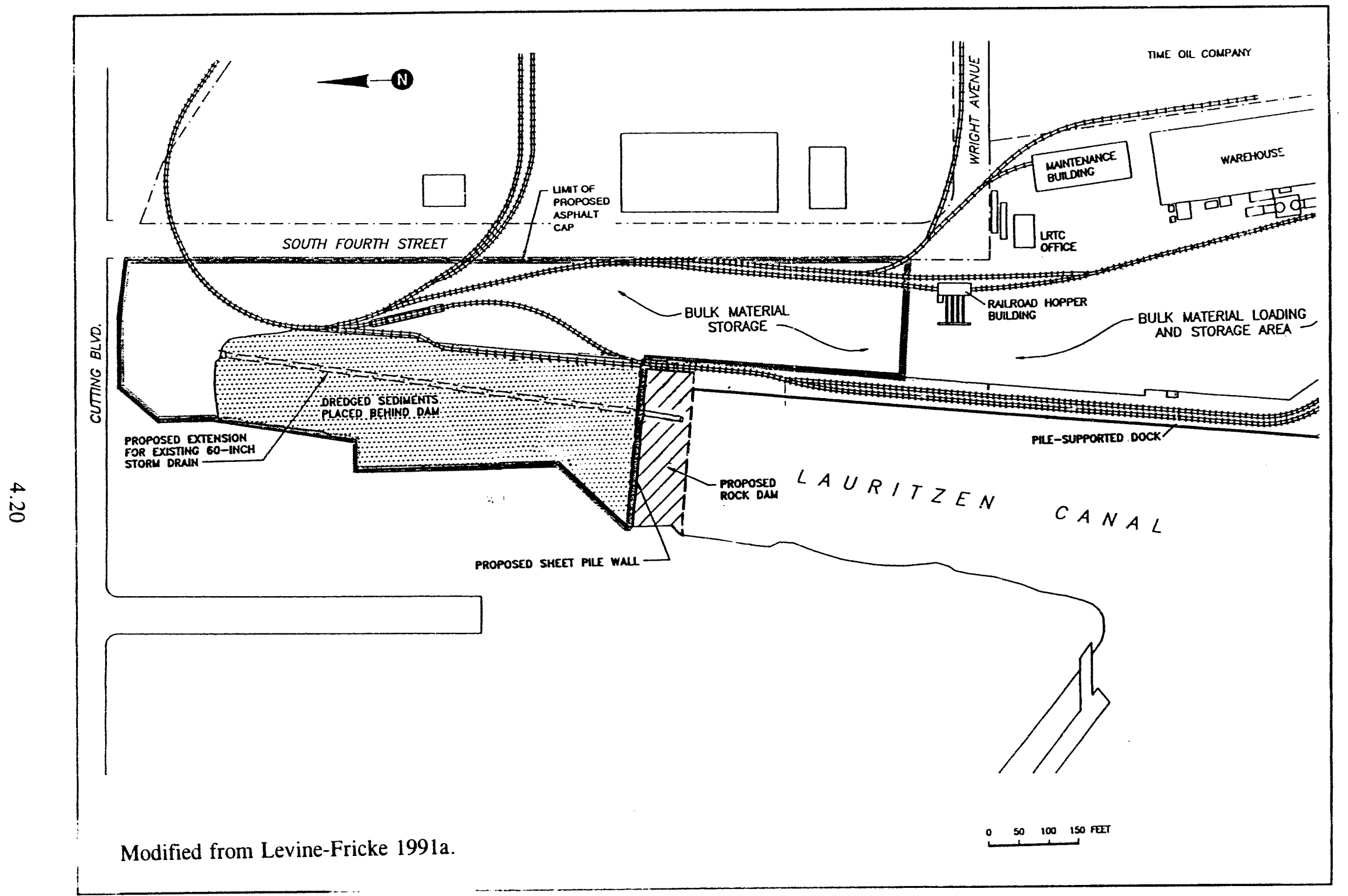

FIGURE 4.7. Configuration of Rock Dam, Alternative 3 


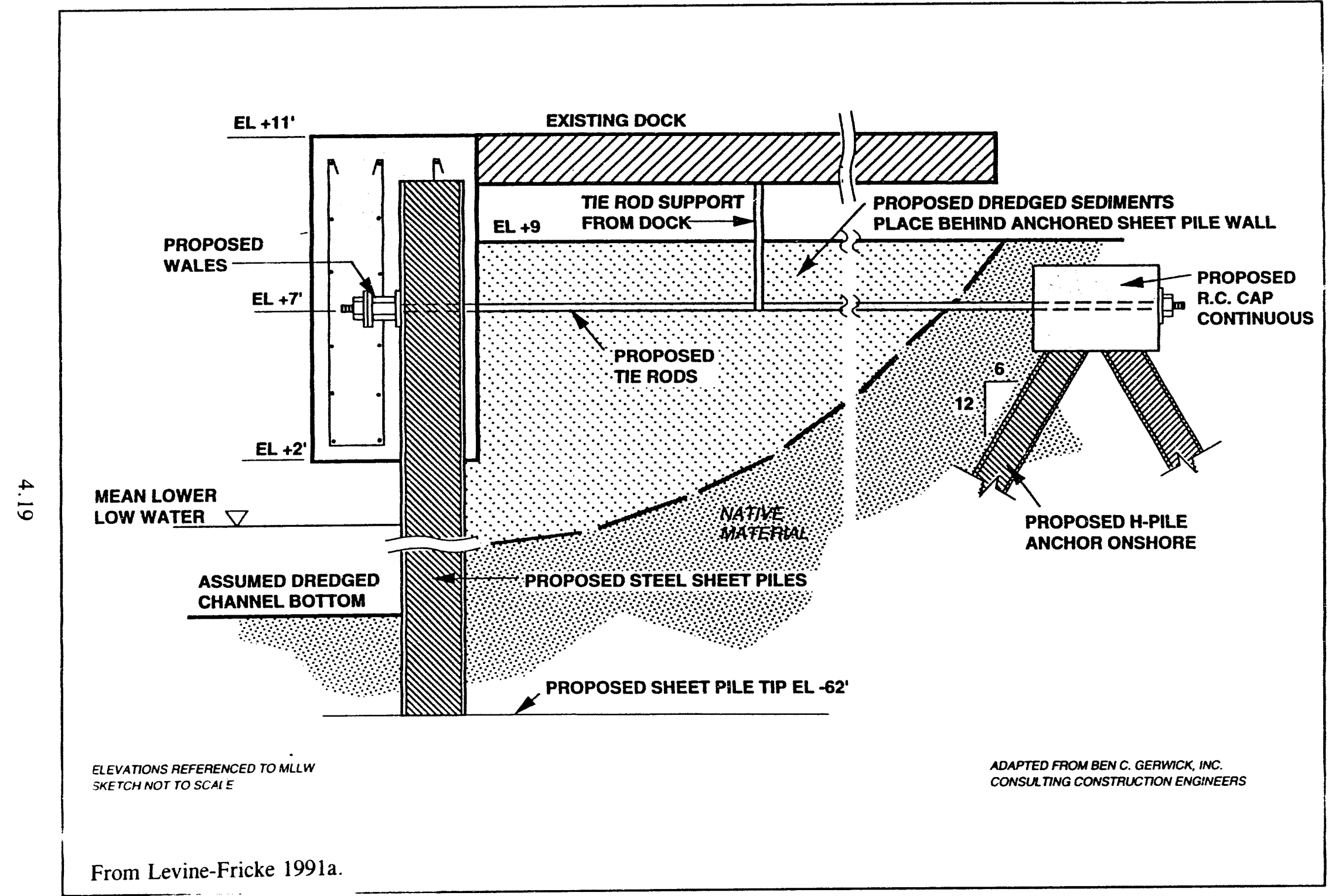

FIGURE 4.6. Cross-Section of Proposed Anchored Bulkhead Along Wharf, Alternative 3 


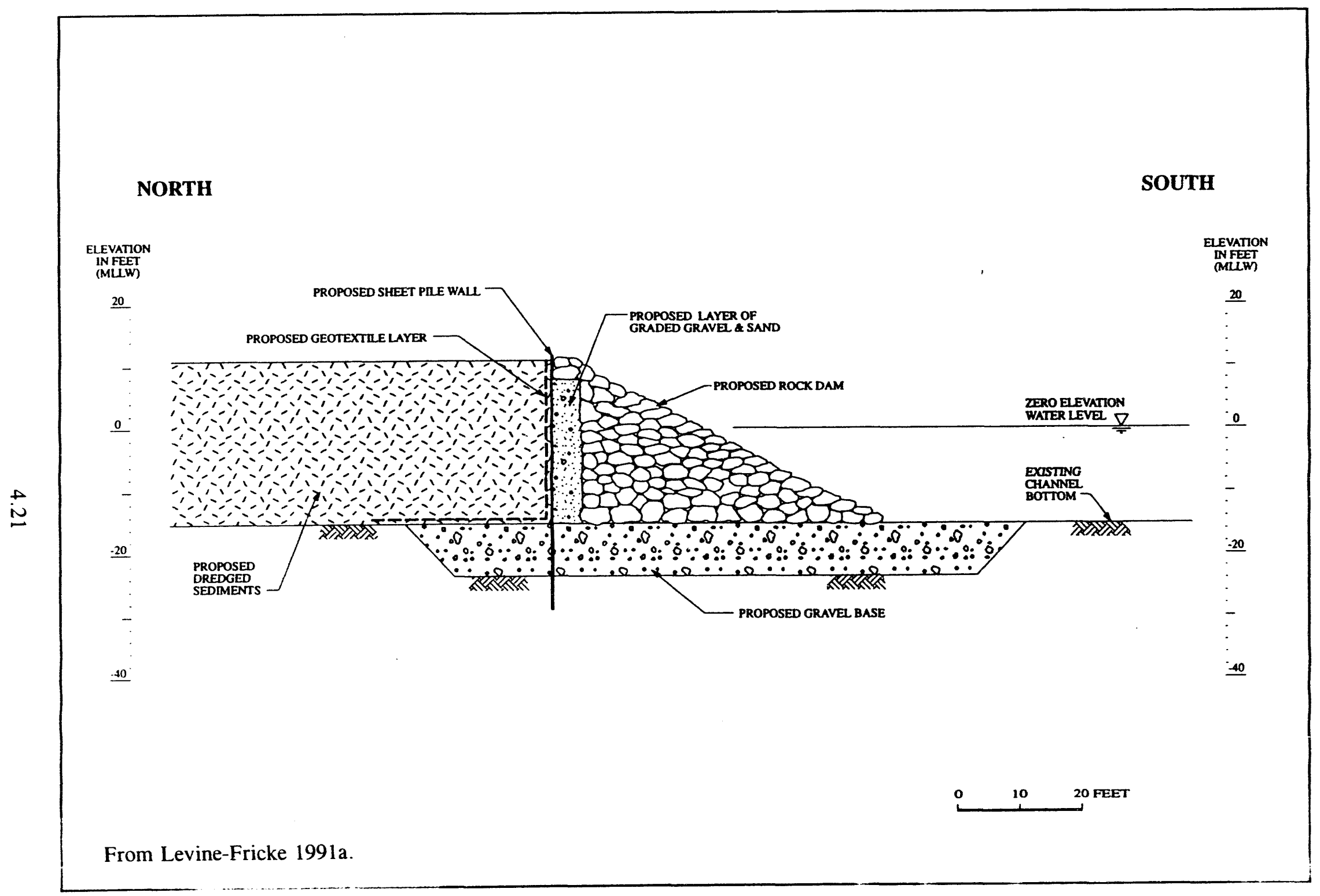

FIGURE 4.8. Cross-Section of Proposed Rock Dam, Alternative 3 
short-term impacts within the excavation areas. The rock dam variation of this alternative would have an impact on adjacent property owners, which could hinder implementability.

Overall Protection of Human Health and the Environment. This alternative would meet the remedial action goals by consolidating and containing contaminated sediments from the Lauritzen Channel and Parr Canal. Concentrations of the COCs in surface waters and marine organisms would be expected to drop to acceptable levels after implementation of the remedy. Short-term impacts would be confined to the currently highly contaminated areas which would be dredged.

Compliance with ARARs. This alternative is expected to achieve compliance with the surface water quality criteria, which are ARARs. Two areas of concern, however, are compliance with ARARs related to filling in the bay and waters of the United States, and facility requirements of the state's HWCL.

The surface area of the CDF would be useable for industrial purposes after consolidation of the sediments; however, this would not significantly enhance port facilities as would the graving dock alternative. The rock dam configuration would, in fact, interfere with port use by decreasing the accessible length of shoreline. The primary purpose of either Lauritzen Chanel CDF configuration would be dredged material disposal. Filling in the bay for disposal would be inconsistent with the San Francisco Bay Plan, and therefore also the CZMA, unless there were no upland disposal alternatives available, or it were necessary for environmental protection. Filling is also prohibited under the Clean Water Act unless there is no practicable alternative available. Under this criterion, this alternative would probably not be eligible for selection unless it is determined that it is the only practicable or available alternative.

The concentration of DDT in sediments consolidated in a Lauritzen Channel CDF would be approximately $30 \mathrm{mg} / \mathrm{kg}$ wet wt, which exceeds the state's TTLC of $1 \mathrm{mg} / \mathrm{kg}$. Since disposal in a CDF would constitute consolidation onsite for the purposes of CERCLA, hazardous wastes would not be generated, and the facility would not have to be permitted as a hazardous waste disposal facility. Nevertheless, some of the requirements of the state's HWCL relating to facility construction and management could still be relevant and appropriate.

Generally, facilities containing state hazardous wastes are required to have liners, leachate collection systems and groundwater monitoring programs in order to protect groundwater. These requirements are not appropriate in this case because of the hydrophobic nature of the COCs, the 
absence of potable shallow groundwater adjacent to the bay, and the fact that the facility would be underlain by approximately $50 \mathrm{ft}$ of consolidated older bay mud which would prevent downward migration of contaminants. Further measures relative to groundwater protection are not appropriate. However, a long-term monitoring program would be established within the Lauritzen Channel to confirm long-term effectiveness in protecting surface water.

After consolidation of the sediments, the facility would be capped with a structure sufficient to support industrial uses. This cap would be sufficient to meet the relevant and appropriate requirements of the HWCL, particularly since the concentration of contaminants beneath the cap would be well within the range of acceptability for industrial exposure.

Long-Term Effectiveness and Permanence. This alternative would be expected to be effective in containing contaminated sediments over a long period. The residual risks associated with this alternative are low. The concentrations of COCs in the consolidated sediments would be well within the range of acceptability if industrial exposure ever were to occur. Long-term maintenance of the structure would be necessary to ensure that the sediments were never released to the marine environment. The long-term effectiveness and permanence of this remedy would be confirmed through environmental monitoring.

Reduction in Toxicity, Mobility, and Volume through Treatment. This alternative does not employ treatment. It does, however, meet the expectation of the NCP for containment of high volumes of waste which have relatively low contaminant concentrations. Based on the process screening conducted in Section 3.0, treatment of the COCs in site sediments would not be practicable.

Short-Term Effectiveness. This alternative would pose no short-term risks to the community during implementation. The dredged sediments would be wet, so there would be no dust generation or wind-borne dispersion. The short-term risks to workers are primarily those inherent to construction, dredging and solids handling. The mean concentrations of COCs in the sediments are well within the range of acceptability for long-term industrial exposure. The parties conducting the remediation would be required to develop a site health and safety plan for workers.

Dredging in the Lauritzen Channel and Parr Canal would have short-term environmental impacts. The dredging process would resuspend sediments within the excavation area. Since some of the contaminated sediments would be contained within the CDF however, this alternative would require the least amount of dredging. Silt curtains would be placed across the mouths of the channels 
prior to dredging to prevent the transport of sediment outside the excavation area. State water quality objectives for the protection of marine life are not currently achieved in the channels proposed for dredging, and would not be expected to be achieved during the remediation. Dredging the channels down to the older bay mud contact would result in the removal of the existing benthic communities from the channels. However, the existing sediment is toxic to some benthic organisms, and it is expected that the channels would be recolonized with a more diverse population.

This alternative would be expected to achieve protection within a relatively short time frame. Levine-Fricke estimated that the entire remediation, including construction of the CDF, would take approximately one year.

Implementability. This alternative is technically implementable. Shoreline CDFs are commonly used to contain contaminated sediments and the technologies required to dredge the channels and construct the facility are known and readily available.

Administratively, the feasibility of either of these alternatives would be limited by opposition from state agency concerns regarding bay fill. The rock dam variation of this alternative may be further limited by its impact to adjacent land owners and operators. Agreements would have to be reached regarding loss of shoreline and access.

Cost. Detailed cost summaries for both variations of this alternative are provided in the appendix. Capital costs include the following elements: design and construction of the CDF; dredging of younger bay mud from part of the Lauritzen Channel and the Parr Canal, and placement in the CDF; treatment of effluent from dewatering sediment; sample collection and analysis to confirm the effectiveness of dredging; and paving of the upland area. Annual overhead and maintenance costs include evaluation and repair of the CDF, operation and maintenance of an effluent treatment system for dewatering sediment; and post-remediation monitoring.

The cost of dredging the sediment for this alternative would be slightly lower than the costs described for the previous alternative since some of the sediment would remain in place and transportation would not be required. The estimated cost range is $\$ 13$ million for the sheet-pile wall variation and $\$ 4.3$ million for the rock dam. In addition, state and federal agencies and the Port of Richmond have indicated that they might seek mitigation to compensate for the fill associated with this alternative. The cost of mitigation would also significantly increase the total cost of this alternative. 


\subsubsection{Alternative 4: Dredging with Offsite Disposal}

\section{Description}

The major components of this alternative are dredging approximately 65,000 cy of contaminated sediment from the Lauritzen Channel and Parr Canal, and transportation of the sediment by rail to a permitted offsite disposal facility. Transport by rail offers several significant advantages. The Levin Richmond Terminal is a rail facility with lines running the length of the shoreline of the Lauritzen Channel. Since dredging can produce very large volumes of sediment very quickly, the limiting factor in removing sediment from the site would be the time required to load it for transport. Dredging would most likely be done mechanically in order to minimize the entrainment of water. Watertight rail cars would be used to prevent releases during transportation. A rail car can carry 100 tons, and a single train can transport approximately 8000 tons. Disposal costs (including transportation by rail) are based on an estimate obtained from a facility in Utah that is permitted to receive non-RCRA wastes and that has estimated that the entire project could be accomplished in about two months.

In addition to the actions described above, this alternative would include the post-remedial monitoring program described in Section 4.2.2, asphalt paving of the northern half of the Levin Richmond Terminal, removal of barges and debris from the Lauritzen Channel, and institutional controls as described in Section 4.2.4.

\section{Evaluation}

This alternative would be expected to meet the remedial action goals defined in Section 2.2, provide effective long-term protection of human health and the environment, and comply with all ARARs. Dredging would cause short-term impacts within the excavation areas. Disposal of sediments at an offsite facility would require no bay fill, and would minimize long-term maintenance costs and liabilities. Offsite disposal by rail appears to be implementable at a reasonable cost.

Overall Protection of Human Health and the Environment. This alternative would meet the remedial action goals by removing contaminated sediments from the Lauritzen Channel and Parr Canal and transporting them to a permitted offsite disposal facility. Concentrations of the COCs in surface waters and marine organisms would be expected to drop to acceptable levels after implementation of the remedy. Short-term impacts would be confined to the currently highly contaminated areas which would be dredged. 
Compliance with ARARs. This alternative is expected to achieve compliance with the federal and state surface water quality criteria and objectives and all other ARARs. Sediments dredged from the site would not be RCRA hazardous wastes and would not require disposal in a RCRA-permitted facility. The disposal facility selected would have to meet the requirements of CERCLA Section 121(d)(3) (42 U.S.C. \$9621[d][3]). Because much of the dredged sediment would exceed the California TTLC for DDT, state regulations regarding the generation, pre-transport and transport of California hazardous waste could be ARARs or otherwise applicable to this alternative (see generally 22 C.C.R. Division 4.5, Chapter 12, Articles 1, 2, 3 and 13).

Long-Term Effectiveness and Permanence. 's is alternative would be expected to provide the greatest long-term effectiveness since contaminated sediments would be removed and transported offsite for disposal. The residual risks associated with this alternative are the lowest since it does not rely on containment in a facility adjacent to the marine environment. The risks of disposal at a permitted facility are minimal since such facilities are designed and operated to prevent the release of wastes. Furthermore, the risks currently associated with the contaminated sediments are due to their location in the marine environment, which aliows direct exposure to marine organisms and bioaccumulation through the aquatic food chain. These exposure pathways would not exist at an offsite disposal facility. In addition, the concentrations of contaminants in the consolidated sediments would be well within the acceptable range for long-term industrial exposure if it ever were to occur. Therefore, the long-term effectiveness of this remedy is expected to be excellent.

Reduction in Toxicity, Mobility, and Volume through Treatment. This alternative does not employ treatment. It does, however, meet the expectation of the NCP for containment of high volumes of waste which have relatively low contaminant concentrations. Based on the process screening conducted in Section 3.0, treatment of the COCs in site sediments would not be practicable.

Short-Term Effectiveness. This alternative would pose no short-term risks to the community during implementation. The dredged sediments would be wet, so there would be no dust generation or wind-borne dispersion. The risks associated with the operation should be only the physical hazards il herent to rail transportation. The concentrations of chemicals in the sediment are a threat because of their current location in the marine environment, and they would not pose a short-term risk to the community even if a spill were to occur during transportation.

The short-term risks to workers are primarily those inherent to rail transportation, dredging and solids handling. The mean concentrations of COCs in the sediments are well within the range of 
acceptability for long-term industrial exposure. The parties conducting the remediation would be required to develop a site health and safety plan for workers.

Dredging in the Lauritzen Channel and Parr Canal would have short-term environmental impacts. The dredging process would resuspend sediments within the excavation area. Silt curtains would be placed across the mouths of the channels prior to dredging to prevent the transport of sediment outside the excavation area. State water quality objectives for the protection of marine life are not currently achieved in the channels proposed for dredging, and would not be expected to be achieved during the remediation. Dredging the channels down to the older bay mud contact would result in the removal of the existing benthic communities from the channels. However, the existing sediment is toxic to some benthic organisms, and it is expected that the channels would be recolonized with a more diverse population. This alternative would be expected to achieve protection within a very short time frame. It is estimated that the dredging and removal operation would take approximately two months.

Implementability. This alternative involves standard construction techniques and should be readily implementable. There should be no administrative impediments to its implementation.

Cost. The estimated cost for this alternative is $\$ 6.8$ million. Since the sediments would be transported offsite to a permitted disposal facility, long-term operations and maintenance costs are only those associated with the monitoring program and maintenance of the asphalt paving at the site. The detailed cost summary for this alternative is presented in the appendix. The estimated disposal cost for this alternative includes transportation by rail and was provided by the East Carbon Development Corporation, a facility in eastern Utah that is permitted to receive non-RCRA wastes.

\subsection{COMPARATIVE ANALYSIS OF REMEDIAL ALTERNATIVES}

In the following analysis, the alternatives are evaluated in relation to one another for each of the seven criteria used to evaluate them individually. The purpose of this analysis is to identify the relative advantages and disadvantages of each alternative. The remaining two criteria, state and community acceptance, will be evaluated after the public comment period. Results of the comparative analysis are summarized in Table 4.1 .

Overall Protection of Human Health and the Environment. All of the aiternatives except no action are expected to provide adequate protection of human health and the environment. The risks 
TABLE 4.1. Comparison of Alternatives

\begin{tabular}{|c|c|c|c|c|}
\hline Criteria $^{(a)}$ & No Action & $\begin{array}{l}\text { Dredging with } \\
\text { Containment at } \\
\text { Port of Ricl nond }\end{array}$ & $\begin{array}{l}\text { Dredging with } \\
\text { Containment in } \\
\text { Lauritzen Channel }\end{array}$ & $\begin{array}{l}\text { Dredging with } \\
\text { Offsite Disposal }\end{array}$ \\
\hline $\begin{array}{l}\text { Overall Protection of Human } \\
\text { Health and the Environment }\end{array}$ & Not protective & Protective & Protective & Protective \\
\hline Compliar e with ARARs & No & Yes & $\begin{array}{l}\text { No, unless no } \\
\text { alternative, available. }\end{array}$ & Yes \\
\hline $\begin{array}{l}\text { Long-term Effectiveness and } \\
\text { Permanence }\end{array}$ & $\mathrm{NA}^{(0)}$ & $\begin{array}{l}\text { Yes. Will require } \\
\text { maintenance. }\end{array}$ & $\begin{array}{l}\text { Yes. Will require } \\
\text { maintenance. }\end{array}$ & Yes \\
\hline $\begin{array}{l}\text { Reduction of Toxicity, Mobility } \\
\text { or Volume Through Treatment }\end{array}$ & NA & No & No & No \\
\hline Short-term Effectiveness & NA & $\begin{array}{l}\text { Remediation in } 12 \\
\text { months. Consolidation of } \\
\text { sediment over several } \\
\text { years. }\end{array}$ & $\begin{array}{l}\text { Reduces dredging. } \\
\text { Remediation in } 12 \\
\text { months. Consolidation } \\
\text { of sediments over } \\
\text { several years. }\end{array}$ & $\begin{array}{l}\text { Remediation in about } 2 \\
\text { months. }\end{array}$ \\
\hline Implementability & NA & $\begin{array}{l}\text { Liability agreements } \\
\text { required. }\end{array}$ & $\begin{array}{l}\text { Not implementable if } \\
\text { alternatives available. }\end{array}$ & Readily implementable. \\
\hline Cost & NA & $\$ 5.6 \mathrm{M}$ & $\$ 4.3 \mathrm{M}$ to $\$ 13 \mathrm{M}$ & $\$ 6.8 \mathrm{M}$ \\
\hline
\end{tabular}


associated with the COCs are due to their current location in or near the aquatic environment. Alternatives 2 and 3 would achieve protection by isolating the contaminants from the aquatic environment in onsite confined disposal facilities. Alternative 4 would achieve protection by transporting contaminants offsite.

Compliance with ARARs. The no action alternative would not result in compliance with ARARs. Alternative 2, confinement in the Port of Richmond's graving docks, relies on the dual purpose of the remedy to create a port facility in order to achieve consistency with the CZMA and compliance with the Clean Water Act. Alternative 3, confinement in the Lauritzen Channel, would probably not be consistent with the CZMA or the Clean Water Act unless it were determined that there were no practicable alternative. Alternative 4, offsite disposal, complies with all ARARs, and appears to be practicable.

Long-term Effectiveness and Permanence. Alternatives 2 through 4 are all expected to provide adequate long-term effectiveness and permanence. Concrete vaults and shoreline CDFs have been used successfully to contain contaminated sediments, although they require perpetual maintenance. Alternative 4, offsite disposal, provides the highest degree of permanence because the contaminated sediments would be stored far from the aquatic environment.

Reduction of Toxicity, Mobility, or Volume Through Treatment. None of the alternatives employs treatment. Alternatives 2 through 4 meet the expectation of the NCP for containment of high volumes of waste which have relatively low contaminant concentrations. Based on the process screening conducted in Section 3.0, treatment of the COCs in site sediments would not be practicable.

Short-term Effectiveness. None of the alternatives would be expected to cause short-term risks to the community. The risks to workers are expected to be primarily those associated with construction, transportation, dredging, and solids handling. All of the dredging alternatives would cause short-term impacts within the excavation areas, and would remove the existing benthic communities from the bottoms of the Lauritzen Channel and Parr Canal. However, it is expected that the channel bottoms would be recolonized by more diverse populations. Alternative 4 , offsite disposal, would achieve protection in the shortest amount of time, approximately two months.

Implementability Alternative 4 is the most readily implementable. It would require the least amount of onsite construction and preparation, and should have no administrative impediments. Alternative 2, consolidation at the Port of Richmond's graving docks, would require a complex 
agreement between the City of Richmond and other parties regarding ownership, operations, and liability. Alternative 3, consolidation in a CDF in the Lauritzen Channel, would likely encounter state opposition, and could require agreements among adjacent property owners regarding loss of shoreline and access.

Cost. The estimated costs for all of the alternatives are comparable. The cost for Alternative 4, offsite disposal, although not the lowest, is probably the most certain. The estimated costs for Alternative 2, confinement at the Port of Richmond's graving docks, and Alternative 3, confinement at the Lauritzen Channel, would be more likely to change given the need for agreements among parties regarding ownership, maintenance and liability for facilities containing wastes exceeding state hazardous levels. In addition, various agencies have indicated that they would seek mitigation for the fill associated with these alternatives which could significantly increase their cost. The costs for construction, dewatering, effluent disposal, and hazardous waste storage are also less certain than the offsite transportation and disposal costs. 


\subsection{REFERENCES}

CH2M Hill. 1987. Work Plan/Revised Remedial Action Plan, Richmond Terminal Corporation Site. Prepared for the California Department of Health Services, Berkeley, California.

CH2M Hill. 1988. Site Characterization Technical Memorandum, Levin Richmond Terminal Corporation Site. Prepared for California Department of Health Services, Berkeley, California.

Cullinane, J. M. Jr., D. E. Averett, R. A. Shafer, C. L. Truitt, and M. R. Bradbury. 1989. "Alternatives for Control/Treatment of Contaminated Dredged Material." In Contaminated Marine Sediments - Assessment and Remediation, pp 221-238, National Academy Press, Washington D.C.

Ecology and Environment, Inc. 1988. CERCLA Expanded Sit. Inspection Report for Levin Richmond Terminal Corporation/United Heckathorn Company, 402 Wright Avenue, Richmond, Contra Costa County, California. Prepared for EPA Region IX, San Francisco, California.

EPA (United States Environmental Protection Agency). 1980. Ambient Water Quality Criteria for Dieldrin. EPA 440/5-80-019. Office of Water Regulations and Standards, Washington, D.C.

EPA (United States Environmental Protection Agency). 1980. Ambient Water Quality Criteria for $D D T$. EPA 440/5-80-038. Office of Water Regulations and Standards, Washington, D.C.

EPA (United States Environmental Protection Agency). 1988. Guidance for Conducting Remedial Investigations and Feasibility Studies Under CERCLA, Interim Final. EPA/540/G-89/004 Office of Emergency and Remedial Response, Washington, D.C.

EPA (United States Environmental Protection Agency) 1989. CERCLA Compliance With Other Laws Manual: Interim Final. EPA 540-G-89-006. Office of Solid Waste and Emergency Response, Washington, D.C.

EPA (United States Environmental Protection Agency) 1993. Selecting Remediation Techniques for Contaminated Sediment. EPA-823-B93-001 Office of Water, Office of Science and Technology, Standards and Applied Science Division and Office of Research and Development, Risk Reduction Engineering Laboratory, Washington, D.C.

EPA (United States Environmental Protection Agency) 1994. Ecological Risk Assessment of the Marine Sediments at the United Heckathorn Superfund Site. ERL-N:N269 EPA Region 9, San Francisco, California.

Goldman, H. B. 1969. "Geology of San Francisco Bay." In Geologic and Engineering Aspects of San Francisco Bay Fill, pp. 9-30, Report 97, California Division of Mines and Geology, San Francisco, California.

HLA (Harding Lawson Associates). 1984. Preliminary Site Characterization, Former United Heckathorn Site, Richmond, California. Prepared by Harding Lawson Associates for the Levin Richmond Terminal Corporation, Novato, California. 
HLA (Harding Lawson Associates). 1986a. Revised Draft Site Characterization and Remedial Action Plan, Former United Heckathorn Site, Richmond, California. Novato, California.

HLA (Harding Lawson Associates). 1986b. Interim Remedial Actions, Train Scale Excavation, United Heckathorn Site, Richmond, California. Novato, California.

Helley, E. J., and K. R. Lajoie. 1979. Flatland Deposits - Their Geology and Engineering Properties and Their Importance to Comprehensive Planning. U.S. Geological Survey Professional Paper 943. Washington, D.C.

ICF Technology, Inc. 1994. Human Health Risk Assessment for the United Heckathorn Superfund Site, Richmond, California. Prepared by ICF Technology for the U.S. Environmental Protection Agency, Region 9, Oakland, California.

JWD (Jordan, Woodman, Dobson). 1994. Revised Dry Dock Basin Study, Port of Richmond. Oakland, California.

Levine-Fricke. 1990. Remedial Investigation, United Heckathorn Site, Richmond, California. Emeryville, California.

Levine-Fricke. 1991a. Feasibility Study Report, United Heckathorn Site, Richmond, California. Emeryville, California.

Levine-Fricke. 1991b. Removal of Pesticide-Affected Soil, United Heckathorn Site, Richmond, California. Emeryville, California.

Levine-Fricke. 1993. Removal of Hot Srot Soils from the United Heckathorn Site, Richmond, California. Emeryville, California.

Long, E., D. MacDonald, M. Baker Matta, K. VanNess, M. Buchman, and H. Harris. 1988. Status and Trends in Concentrations of Contaminants and Measures of Biological Stress in San Francisco Bay. NOAA Technical Memorandum NOS OMA 41, Seattle, Washington.

McLellan, T. N., R. N. Havis, D. F. Hayes, and G. L. Raymond. 1989. Field Studies of Sediment Resuspension Characteristics of Selected Dredges. Technical Report HL-89-9. U.S. Army Engineer Waterways Experiment Station, Vicksburg, Mississippi.

Morton, R. W. 1989. "Monitoring the Effectiveness of Capping for Isolating Contaminated Sediments." In Contaminated Marine Sediments - Assessment and Remediation, pp. 262-279, National Academy Press, Washington, D.C.

Palermo, M. R. 1986. Development of a Modified Elutriate Test for Predicting the Quality of Effluent From Confined Dredged Material Disposal Areas. Technical Report D-86-4, U.S Army Engineer Waterways Experiment Station, Vicksburg, Mississippi.

Palermo, M. R., and E. L. Thackston, 1988. "Test For Dredged Material Effluent Quality." J. of Env. Eng. Vol. 114. 
Parametrix. 1991. Site Reconnaissance at the United Heckathorn Site, Lauritzen Canal. Prepared by Parametrix for United Heckathorn, Bellevue, Washington.

SFBRWQCB (San Francisco Bay Regional Water Quality Control Board). 1992. Water Quality Control Plan for the San Francisco Bay Basin, Amended September 16, 1992. Oakland, California.

Strenge, D. L., and F. R. Peterson. 1989. Chemical Databases for the Multi-Media Environmental Pollution Assessment System (MEPAS): Version 1. PNL-7145. Pacific Northwest Laboratory, Richland, Washington.

Weston, R. F. 1993. Final Report for the United Heckathorn Site. W.0-00709-031-001. Walnut Creek, California.

White, P. J., N. P. Kohn, W. W. Gardiner, and J. Q. Word. 1994. Remedial Investigation of Marine Sediment at the United Heckathorn Superfund Site. PNL-9383. Pacific Northwest Laboratory, Richland, Washington.

Zappi, P. A., and D. F. Hayes. 1991. Innovative Technologies for Dredging Contaminated Sediments. Miscellaneous Paper EL-91-20. U.S Army Engineer Waterways Experiment Station, Vicksburg, Mississippi. 
APPENDIX

COST ESTIMATES 
ALTERNATIVE 1: NO ACTION

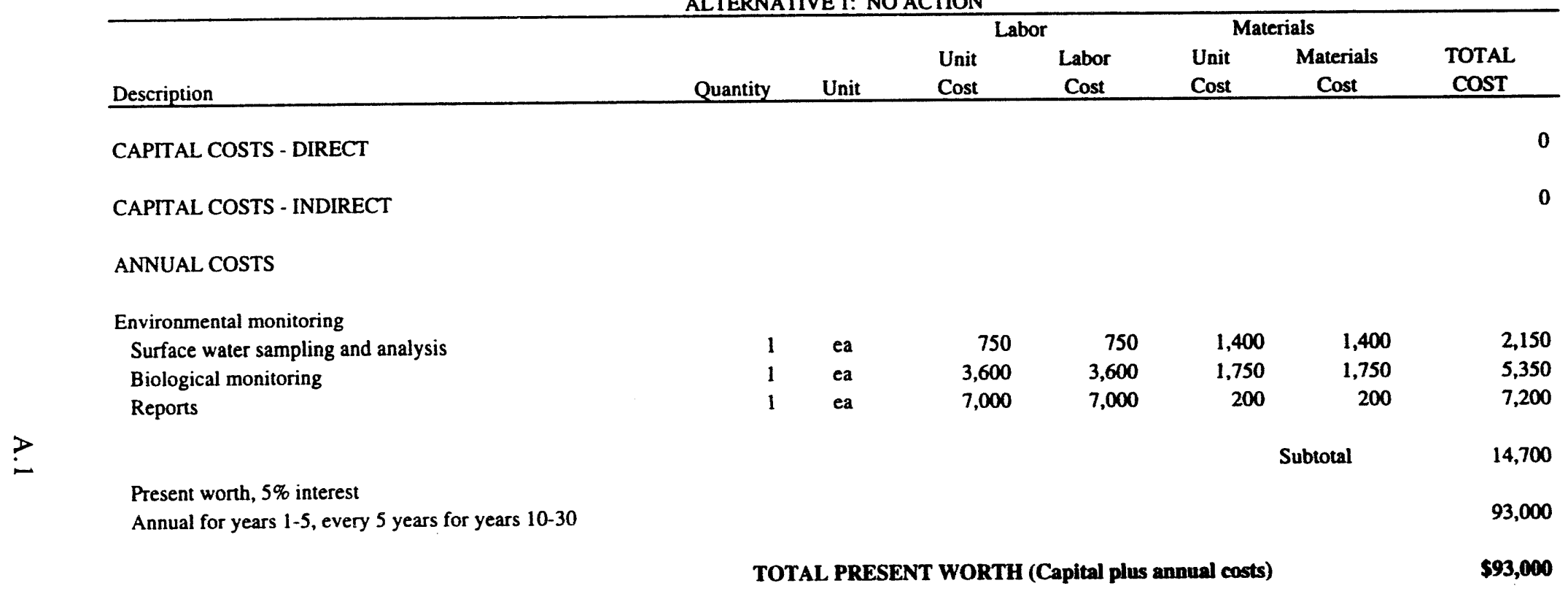




\begin{tabular}{|c|c|c|}
\hline & & \multirow[b]{2}{*}{$\begin{array}{c}\text { TOTAL } \\
\text { COST }\end{array}$} \\
\hline & & \\
\hline
\end{tabular}

\section{CAPITAL COSTS - DIRECT}

Design and Conversion of Point Potrero Graving Docks (from JWD 1994 report for Alternative I)

Basin Closure

Clean up basin and prep

Bottom subdrain blanket

Sidewall drains

Wick drains

Dewatering pumping

Basin closure top beam

Demo craneway and bldg, lengthen Basin 3

Dredging outside basins

i

AC paving over fill (future)

Dredging Lauritzen Channel and Parr Canal

Mobilization

Silt screen

Set timber piles

Steel cable

Screen

Maintenance

Salvage and disposal of submerged barges and tank

Dredging

$\begin{aligned} 1 & \text { ea } \\ 1 & \text { ea } \\ 60,000 & \text { sf } \\ 9,360 & \text { sf } \\ 86,400 & \text { If } \\ 89,000 & \text { cy } \\ 100 & \text { sf } \\ 1 & \text { Is } \\ 13,333 & \text { cy } \\ 54,000 & \text { sf }\end{aligned}$

$\begin{array}{rr}300,000 & 300,000 \\ 20,000 & 20,000 \\ & \\ 0.05 & 4,450 \\ & \\ 1,800,000 & 1,800,000 \\ 5 & 66,665\end{array}$

\begin{tabular}{rrr} 
& & 300,000 \\
0.50 & 30,000 & 20,000 \\
0.50 & 4,680 & 30,000 \\
0.40 & 34,560 & 4,680 \\
& & 34,560 \\
1,000 & 100,000 & 4,450 \\
& & 100,000 \\
& & $1,800,000$ \\
2.50 & 135,000 & 66,665 \\
& & 135,000 \\
\hline & & \\
& & \\
& &
\end{tabular}

$\begin{array}{rcrr}1 & \text { ea } & 100,000 & 100,000 \\ 10 & \text { item } & & \\ 500 & \text { If } & & \\ 10,000 & \text { sf } & & \\ 1 & \text { is } & 4,500 & 4,500 \\ 1 & \text { ea } & 130,000 & 130,000 \\ 65,000 & \text { cy } & 10 & 650,000\end{array}$

100,000

\begin{tabular}{lrr}
1,000 & 10,000 & 10,000 \\
1.00 & 500 & 500 \\
1.50 & 15,000 & 15,000 \\
& & 4,500 \\
& & 130,000 \\
& & 650,000 \\
\hline
\end{tabular}

Subtotal $\quad 910,000$ 


\begin{tabular}{|c|c|c|c|c|c|c|c|}
\hline \multirow[b]{2}{*}{ D } & \multirow[b]{2}{*}{ Quantity } & \multirow[b]{2}{*}{ Unit } & \multicolumn{2}{|c|}{ Labor } & \multicolumn{2}{|c|}{ Materials } & \multirow[b]{2}{*}{$\begin{array}{l}\text { TOTAL } \\
\text { COST }\end{array}$} \\
\hline & & & $\begin{array}{l}\text { Unit } \\
\text { Cost }\end{array}$ & $\begin{array}{c}\text { Labor } \\
\text { Cost }\end{array}$ & $\begin{array}{l}\text { Unit } \\
\text { Cost }\end{array}$ & $\begin{array}{c}\text { Materials } \\
\text { Cost }\end{array}$ & \\
\hline
\end{tabular}

Effluent Treatment

(from 12/22/93 letter from Levine-Fricke to EPA)

Water treatment system

carbon units/delivery

pumps, filters, and controls

piping

carbon ( $1 \# / 1000 \mathrm{~g}$ est)

Treatability studies

\begin{tabular}{rcrrrrr}
3 & ea & 1,000 & 3,000 & 5,000 & 15,000 & 18,000 \\
1 & item & 5,000 & 5,000 & 8,000 & 8,000 & 13,000 \\
1 & item & 2,000 & 2,000 & 2,000 & 2,000 & 4,000 \\
25,000 & lbs & & & 2.50 & 62,500 & 62,500 \\
1 & ea & 8,000 & 8,000 & 50,000 & 50,000 & 58,000 \\
\cline { 3 - 6 } & & & \multicolumn{2}{c}{ Subtotal } &
\end{tabular}

Confirmation sampling

Sediment sample collection, analysis, report

Upland Area Cap

(from Levine-Fricke 1991a)

Mobilization

Site preparation

Grading and compacting

Asphalt surface seal w/ AB

$\begin{array}{rr}1 & \text { ea } \\ 1 & \text { ea } \\ 12,375 & \text { sy } \\ 24,750 & \text { sy }\end{array}$

$\begin{array}{rr}5,000 & 5,000 \\ 6,000 & 6,000 \\ 2 & 24,750\end{array}$

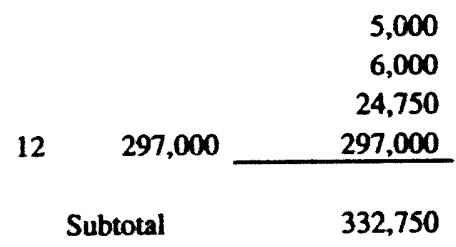

Total Direct Costs

$3,914,605$ 


\begin{tabular}{|c|c|c|c|c|c|c|c|}
\hline \multirow[b]{2}{*}{ Description } & \multirow{2}{*}{ Quantity } & \multirow[b]{2}{*}{ Unit } & \multicolumn{2}{|c|}{ Labor } & \multicolumn{2}{|c|}{ Materials } & \multirow[b]{2}{*}{$\begin{array}{l}\text { TOTAL } \\
\text { COST }\end{array}$} \\
\hline & & & Unit & $\begin{array}{l}\text { Labor } \\
\text { Cost }\end{array}$ & $\begin{array}{l}\text { Unit } \\
\text { Cost }\end{array}$ & $\begin{array}{l}\text { Materials } \\
\text { Cost }\end{array}$ & \\
\hline
\end{tabular}

CAPITAL COSTS - INDIRECT

Contingency

Engineering Design

Construction Managment

$20 \% \mathrm{X}$ total direct costs

7\% $\mathrm{X}$ total direct costs

782,921

$7 \% \times$ total direct costs
$5 \% \times$ total direct costs

274,022

195,730

Total Indirect Costs

$1,252,674$

Total Capital Costs (Direct + Indirect)

$5,167,279$

ANNUAL COSTS

Operation and maintenace of graving docks

Structural evaluation

General repairs

Subtotal

Present Worth, 5\% interest, 30 year term

Effluent treatment system

Operation

Maintenance

Subtotal

Present Worth, 5\% interest, 20 year term

Post remediation monitoring (see Alternative 1 )

Present worth, $5 \%$ interest

Annual for 5 years, every five years from years $10-30$

93,000

Total Present Worth Annual Costs

433,600

TOTAL PRESENT WORTH (CAPITAL + ANNUAL COSTS)

$\$ 5,600,879$ 
ALTERNATIVE 3: CONFINED DISPOSAL OF MARINE SEDIMENT IN LAURITZEN CHANNEL

CONSTRUCTION OF SHEETPILE BULKHEAD ON EAST SHORE OF LAURITZEN CHANNEL

\begin{tabular}{|c|c|c|c|c|c|c|c|}
\hline \multirow[b]{2}{*}{ Description } & \multirow[b]{2}{*}{ Quantity } & \multirow[b]{2}{*}{ Unit } & \multicolumn{2}{|c|}{ Labor } & \multicolumn{2}{|c|}{ Materials } & \multirow[b]{2}{*}{$\begin{array}{c}\text { TOTAL } \\
\text { COST }\end{array}$} \\
\hline & & & $\begin{array}{l}\text { Unit } \\
\text { Cost }\end{array}$ & $\begin{array}{l}\text { Labor } \\
\text { Cost }\end{array}$ & $\begin{array}{l}\text { Unit } \\
\text { Cost }\end{array}$ & $\begin{array}{c}\text { Materials } \\
\text { Cost }\end{array}$ & \\
\hline
\end{tabular}

CAPITAL COSTS - DIRECT

Construction of Sheetpile Bulkhead

(from 12/22/93 letter from Levine-Fricke to EPA)

Mobilization

Arbed sheet pile sections

Tie rods under dock

Tie rods north of dock

HP Piles (12X63)

HP Piles (12X53)

Concrete deadmen

Painting steel sheets

Cathodic protection

Wales

Geotextile backing

Reinforced concrete cap

Remove and replace fenders

$\begin{array}{rcrr}1 & \text { ea } & 5,000 & 5,000 \\ 1,200 & \text { If } & 390 & 468,000 \\ 1,200 & \text { If } & 204 & 244,800 \\ 1,200 & \text { If } & 220 & 264,000 \\ 1,200 & 12 \text { If } & 170 & 204,000 \\ 1,200 & 12 \text { If } & 170 & 204,000 \\ 660 & \text { cy } & & \\ 60,000 & \text { sf } & 1 & 45,000 \\ 1,200 & \text { If } & & \\ 1,200 & \text { If } & 14 & 16,800 \\ 1,200 & \text { If } & 25 & 30,000 \\ 1,200 & \text { If } & 440 & 528,000 \\ 1,200 & \text { If } & 220 & 264,000\end{array}$

\begin{tabular}{rrr}
2,810 & $3,372,000$ & 5,000 \\
610 & 732,000 & 970,000 \\
110 & 132,000 & 396,000 \\
245 & 294,000 & 498,000 \\
415 & 498,000 & 702,000 \\
440 & 290,400 & 290,400 \\
1 & 45,000 & 90,000 \\
55 & 66,000 & 66,000 \\
42 & 50,400 & 67,200 \\
25 & 30,000 & 60,000 \\
440 & 528,000 & $1,056,000$ \\
& & 264,000 \\
\hline & & \\
& Subtotal & $8,311,400$
\end{tabular}




\begin{tabular}{|c|c|c|c|c|c|c|c|}
\hline \multirow[b]{2}{*}{ escription } & \multirow[b]{2}{*}{ Quantity } & \multirow[b]{2}{*}{ Unit } & \multicolumn{2}{|c|}{ Labor } & \multicolumn{2}{|c|}{ Materials } & \multirow[b]{2}{*}{$\begin{array}{l}\text { TOTAL } \\
\text { COST }\end{array}$} \\
\hline & & & $\begin{array}{l}\text { Unit } \\
\text { Cost }\end{array}$ & $\begin{array}{l}\text { Labor } \\
\text { Cost }\end{array}$ & $\begin{array}{l}\text { Unit } \\
\text { C }>\text { st }\end{array}$ & $\begin{array}{c}\text { Materials } \\
\text { Cost }\end{array}$ & \\
\hline
\end{tabular}

Dredging Part of Lauritzen Channel and Parr Canal

Mobilization
Silt screen
Set timber piles
Steel cable
Screen
Maintenance
Salvage and disposal of submerged barges and tank
Dredging

Dredging

Installation of cap over confined disposal facility

(from 12/22/93 letter from Levine-Fricke to EPA)

Gravel/geotextile cap

Effluent Treatment (see Alternative 2)

Confirmation sampling (see Alternative 2)

Upland Area Cap (see Alternative 2)

$\begin{array}{rcrrrrr}1 & \text { ea } & 100,000 & 100,000 & & & 100,000 \\ 10 & \text { item } & & & 1,000 & 10,000 & 10,000 \\ 500 & \text { If } & & & 1.00 & 500 & 500 \\ 10,000 & \text { sf } & & & 1.50 & 15,000 & 15,000 \\ 1 & \text { Is } & 4,500 & 4,500 & & & 4,500 \\ 1 & \text { ea } & 130,000 & 130,000 & & & 130,000 \\ 52,000 & \text { cy } & 7 & 364,000 & & & 364,000 \\ & & & & & \text { Subtotal } & \\ & & & & & & \end{array}$

8700

sy

8,700

5

43,500

52,200

155,500

21,000

332,750

Total Direct Costs

$9,496,850$ 


\begin{tabular}{|c|c|c|c|c|c|c|c|}
\hline & & & \multicolumn{2}{|c|}{ Labor } & \multicolumn{2}{|c|}{ Materials } & \\
\hline & Ouantity & Unit & $\begin{array}{l}\text { Unit } \\
\text { Cost }\end{array}$ & $\begin{array}{r}\text { Labor } \\
\text { Cost }\end{array}$ & $\begin{array}{l}\text { Unit } \\
\text { Cost }\end{array}$ & $\begin{array}{c}\text { Materials } \\
\text { Cost }\end{array}$ & $\begin{array}{l}\text { TOTAL } \\
\text { COST }\end{array}$ \\
\hline
\end{tabular}

\section{CAPITAL COSTS - INDIRECT}

Contingency

Engineering Design

Construction Managment
$20 \% \mathrm{X}$ total direct costs

7\% $X$ total direct costs

$5 \% \mathrm{X}$ total direct costs

Total Indirect Costs

Total Capital Costs (Direct + Indirect)
$1,899,370$

664,780

474,843

$3,038,992$

$12,535,842$

\section{ANNUAL COSTS}

Operation and maintenace of confined disposal facility Structural evaluation

General repairs

Subtotal

Present Worth, $5 \%$ interest, 30 year term

Effluent treatment system

Operation

Maintenance

Subtotal

Present Worth, 5\% interest, 20 year term

Post remediation monitoring (see Alternative 1)

Present worth, $5 \%$ interest

Annual for 5 years, every five years from years $10-30$

$\begin{array}{rrrrrrr}1 & \text { ea } & 8,000 & 8,000 & 2,000 & 2,000 & 10,000 \\ 1 & \text { ea } & 9,000 & 9,000 & 1,000 & 1,000 & 10,000 \\ & & & & & & 20,000 \\ & & & & & & 307,400 \\ & & & & & & \\ 1 & \text { ea } & 10,000 & 10,000 & & & 10,000 \\ 1 & \text { ea } & 4,000 & 4,000 & 1,000 & 1,000 & 5,000 \\ & & & & & & 15,000 \\ & & & & & 186,900\end{array}$

93,000

587,300

TOTAL PRESENT WORTH (CAPITAL + ANNUAL COSTS)

$\$ 13,123,142$ 
CONSTRUCTION OF ROCK DAM ACROSS LAURITZEN CHANNEL

\begin{tabular}{|c|c|c|c|c|c|c|c|}
\hline \multirow[b]{2}{*}{ Description } & \multirow[b]{2}{*}{ Quantity } & \multirow[b]{2}{*}{ Unit } & \multicolumn{2}{|c|}{ Labor } & \multicolumn{2}{|c|}{ Materials } & \multirow[b]{2}{*}{$\begin{array}{l}\text { TOTAL } \\
\text { COST }\end{array}$} \\
\hline & & & $\begin{array}{l}\text { Unit } \\
\text { Cost }\end{array}$ & $\begin{array}{c}\text { Labor } \\
\text { Cost } \\
\end{array}$ & $\begin{array}{l}\text { Unit } \\
\text { Cost } \\
\end{array}$ & $\begin{array}{c}\text { Materials } \\
\text { Cost }\end{array}$ & \\
\hline
\end{tabular}

CAPITAL COSTS - DIRECT

Construction of Rock Dam

(Modified fom 12/22/93 letter from Levine-Fricke to EPA)

Subexcavation

Gravel backfill

Steel sheet piles

Coal tar epoxy coating

Cathodic protection

Rock

Geotextile

Extend RCP storm drain

\section{Dredging Part of Lauritzen Channel and Parr Canal}

Mobilization
Silt screen
Set timber piles
Steel cable
Screen
Maintenance
Salvage and disposal of one submerged barge
Dredging

$\begin{array}{rc}9,600 & \text { cy } \\ 11,200 & \text { ton } \\ 14,000 & \text { sf } \\ 14,000 & \text { sf } \\ 14,000 & \text { sf } \\ 12,800 & \text { ton } \\ 55,200 & \text { sf } \\ 800 & \text { lf }\end{array}$

$\begin{array}{rr}10 & 96,000 \\ 5 & 56,000 \\ 5 & 70,000 \\ 1 & 6,600 \\ & \\ 5 & 64,000 \\ & 3,450 \\ 140 & 112,000\end{array}$

\begin{tabular}{rrr} 
& & 96,000 \\
20 & 224,000 & 280,000 \\
25 & 350,000 & 420,000 \\
1 & 11,200 & 17,800 \\
1 & 18,200 & 18,200 \\
25 & 320,000 & 384,000 \\
1 & 27,600 & 31,050 \\
530 & 424,000 & 536,000 \\
\cline { 2 - 3 } & & \\
& Subtotal & $1,783,050$
\end{tabular}

$\begin{array}{rcrr}1 & \text { ea } & 100,000 & 100,000 \\ 10 & \text { item } & & \\ 500 & \text { If } & & \\ 10,000 & \text { sf } & & \\ 1 & \text { ls } & 4,500 & 4,500 \\ 1 & \text { ea } & 40,000 & 40,000 \\ 47,000 & \text { cy } & 7 & 329,000\end{array}$

100,000

\begin{tabular}{rrr}
1,000 & 10,000 & 10,000 \\
1.00 & 500 & 500 \\
1.50 & 15,000 & 15,000 \\
& & 4,500 \\
& & 40,000 \\
& & 329,000 \\
\cline { 3 - 3 } & & 499,000
\end{tabular}




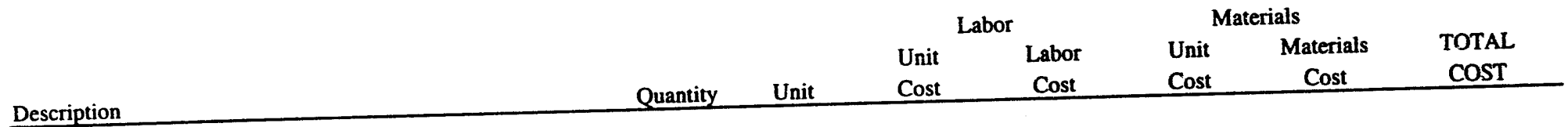

Installation of cap over confined disposal facility

(Modified from 12/22/93 letter from Levine-Fricke to EPA)

Clay/asphalt cap

13,000 sy

$1 \quad 13,000$

$5 \quad 65,000$

78,000

Effluent Treatment (see Alternative 2)

Confirmation sampling (see Alternative 2)

21,000

Upland Area Cap (see Alternative 2)

332,750

Total Direct Costs

$2,869,300$

CAPITAL COSTS - INDIRECT

Contingency

Engineering Design

Construction Managment

\title{
ANNUAL COSTS
}

\author{
Operation and maintenace of confined disposal facility \\ Structural evaluation \\ General repairs \\ Subtotal \\ Present Worth, 5\% interest, 30 year term
}

$\begin{array}{rrrrrr}\text { ea } & 4,000 & 4,000 & 1,000 & 1,000 & 5,000 \\ \text { ea } & 9,000 & 9,000 & 1,000 & 1,000 & 10,000 \\ & & & & & 15,000 \\ & & & & & 230,600\end{array}$




\begin{tabular}{|c|c|c|c|c|c|c|c|}
\hline \multirow[b]{2}{*}{ Description } & \multirow[b]{2}{*}{ Quantity } & \multirow[b]{2}{*}{ Unit } & \multicolumn{2}{|c|}{ Labor } & \multicolumn{2}{|c|}{ Materials } & \multirow[b]{2}{*}{$\begin{array}{l}\text { TOTAL } \\
\text { COST }\end{array}$} \\
\hline & & & $\begin{array}{l}\text { Unit } \\
\text { Cost }\end{array}$ & $\begin{array}{c}\text { Labor } \\
\text { Cost }\end{array}$ & $\begin{array}{l}\text { Unit } \\
\text { Cost }\end{array}$ & $\begin{array}{l}\text { Materials } \\
\text { Cost }\end{array}$ & \\
\hline \multicolumn{8}{|l|}{ Effluent treatment system } \\
\hline Operation & 1 & ea & 10,000 & 10,000 & & & 10,000 \\
\hline Maintenance & 1 & ea & 4,000 & 4,000 & 1,000 & 1,000 & 5,000 \\
\hline Subtotal & & & & & & & 15,000 \\
\hline Present Worth, $5 \%$ interest, 20 year term & & & & & & & 186,900 \\
\hline \multirow{2}{*}{\multicolumn{8}{|c|}{$\begin{array}{l}\text { Post remediation monitoring (see Alternative 1) } \\
\text { Present worth, } 5 \% \text { interest }\end{array}$}} \\
\hline & & & & & & & \\
\hline \multirow{2}{*}{ Annual for 5 years, every five years from years $10-30$} & & & & & & & 93,000 \\
\hline & & \multicolumn{5}{|c|}{ Total Present Worth Annual Costs } & 510,500 \\
\hline
\end{tabular}




\begin{tabular}{|c|c|c|c|c|c|c|c|}
\hline \multirow[b]{2}{*}{ Description } & \multirow[b]{2}{*}{ Quantity } & \multirow[b]{2}{*}{ Unit } & \multicolumn{2}{|c|}{ Labor } & \multicolumn{2}{|c|}{ Materials } & \multirow[b]{2}{*}{$\begin{array}{c}\text { TOTAL } \\
\text { COST }\end{array}$} \\
\hline & & & $\begin{array}{l}\text { Unit } \\
\text { Cost }\end{array}$ & $\begin{array}{c}\text { Labor } \\
\text { Cost }\end{array}$ & $\begin{array}{l}\text { Unit } \\
\text { Cost } \\
\end{array}$ & $\begin{array}{c}\text { Materials } \\
\text { Cost }\end{array}$ & \\
\hline
\end{tabular}

\section{CAPITAL COSTS - DIRECT}

Dredging Lauritzen Channel and Parr Canal

Mobilization

Silt screen

Set timber piles

Steel cable

Screen

Maintenance

Salvage and disposal of submerged barges and tank

Dredging

$\stackrel{?}{=}$

\section{Transportation and disposal at permitted facility}

Confirmation sampling (see Alternative 2)

Upland Area Cap (see Alternative 2)

$\begin{array}{rcrr}1 & \text { ea } & 100,000 & 100,000 \\ 10 & \text { item } & & \\ 500 & \text { If } & & \\ 10,000 & \text { sf } & & \\ 1 & \text { ls } & 4,500 & 4,500 \\ 1 & \text { ea } & 130,000 & 130,000 \\ 65,000 & \text { cy } & 7 & 455,000\end{array}$

$60 \quad 4,485,000$
100,000

\begin{tabular}{rrr}
1,000 & 10,000 & 10,000 \\
1.00 & 500 & 500 \\
1.50 & 15,000 & 15,000 \\
& & 4,500 \\
& & 130,000 \\
& & 455,000 \\
\hline
\end{tabular}

Subtotal

715,000

$4,485,000$

21,000

332,750

$5,553,750$ 


\begin{tabular}{|c|c|c|c|c|c|c|c|}
\hline \multirow[b]{2}{*}{ Description } & \multirow[b]{2}{*}{ Quantity } & \multirow[b]{2}{*}{ Unit } & \multicolumn{2}{|c|}{ Labor } & \multicolumn{2}{|c|}{ Materials } & \multirow[b]{2}{*}{$\begin{array}{l}\text { TOTAL } \\
\text { COST }\end{array}$} \\
\hline & & & $\begin{array}{l}\text { Unit } \\
\text { Cost }\end{array}$ & $\begin{array}{c}\text { Labor } \\
\text { Cost }\end{array}$ & $\begin{array}{l}\text { Unit } \\
\text { Cost }\end{array}$ & $\begin{array}{c}\text { Materials } \\
\text { Cost } \\
\end{array}$ & \\
\hline \multicolumn{8}{|c|}{ CAPITAL COSTS - INDIRECT } \\
\hline \multirow[t]{2}{*}{ Contingency } & \multicolumn{3}{|c|}{$20 \% X$ total direct costs } & & & & $1,110,750$ \\
\hline & & & \multicolumn{4}{|c|}{ Total Indirect Costs } & $1,110,750$ \\
\hline
\end{tabular}

\section{ANNUAL COSTS}

Post remediation monitoring (see Alternative 1)

Present worth, 5\% interest

Annual for 5 years, every five years from years 10 - 30

93,000

Total Present Worth Annual Costs

93,000

TOTAL PRESENT WORTH (CAPITAL + ANNUAL COSTS)

$\$ 6,757,500$ 


\section{DISTRIBUTION}

No. of

Copies

\section{OFFSITE}

12 DOE/Office of Scientific and Technical Information

8 A. Lincoff U.S. Environmental Protection Agency Mail Code H-6-5

75 Hawthorne Street

San Francisco, CA 94105

A. Rakstins

U.S. Army Corps of Engineers

211 Main Street

San Francisco, CA 94105

H. Clark

West County Toxics Coalition

1019 Macdonald Avenue

Richmond, CA 94801

J. Farah

Planning Department

2600 Barrett Avenue

Richmond, CA 94804

S. Gladstone

Regional Water Quality Control Board

2101 Webster Street, Suite 500

Oakland, CA 94612

S. Goldbeck

Bay Conservation and Development

Commission

30 Van Ness Avenue, Suite 2011

San Francisco, CA 94102-6080
No. of

Copies

OFFSITE (contd)

\section{J. Haas}

U.S. Fish and Wildlife Service 2800 Cottaga Way

Sacramento, CA 95825

M. Herz

Baykeeper

Fort Mason, Building A

San Francisco, CA 94123

J. Hilinski

Grubb \& Ellis Co.

1111 Broadway, Suite 2150

Oakland, CA 94607

D. Klimas

National Oceanic and Atmospheric Administration

75 Hawthorne Street (H-1-2)

San Francisco, CA 94105

L. Jackson

Santa Fe Neighborhood Association

240 S. 6th Street

Richmond, CA 94804

L. Johnson

Congressman George Miller

367 Civic Drive, Suite 14

Pleasant Hill, CA 94523

L. Lee

Save the Bay

$173 j$ Franklin Street, 3rd Floor

Oakland, CA 94612

Distr. 1 


\section{DISTRIBUTION (contd)}

No. of

Copies

OFFSITE (contd)

S. Luoma

U.S. Geological Survey

Mail Stop 465

345 Middlefield Road

Menlo Park, CA 94025

M. Martin

California Department of Fish and

Game

20 Lower Ragsdale Drive

Monterey, CA 93940

P. Maynard

Sierra Club

6014 College Avenue

Oakland, CA 94618

E. Serex

Port of Richmond

P.O. Box 4046

Richmond, CA 94804

J. Soto

Department of Toxic Substances

Control

700 Heinz Aven!e, Building F

Berkeley, CA 94710

A. Wanken

Versar, Inc.

5330 Primrose Dr., Suite 228

Fair Oaks, CA 95628
No. of

Copies

QNSITE

DOE Richland Operations Office

P. W. Kruger

A5-90

$\underline{\text { Pacific Northwest Laboratory }}$

G. Costan

1451 River Park Dr., Suite 145

Sacramento, CA 95815

M. Montgomery

1451 River Park Dr., Suite 145

Sacramento, CA 95815

10 L. M. Gully

SEQUI

P. J. White

SEQUI

J. Q. Word

SEQUI

Publishing Coordination

Technical Report Files (5)

Routing

R. M. Ecker

SEQUI

M. J. Graham

K6-78

P. M. Irving

K6-98

C. S. Sloane

K6-04

P. C. Hays (last)

Distr. 2 

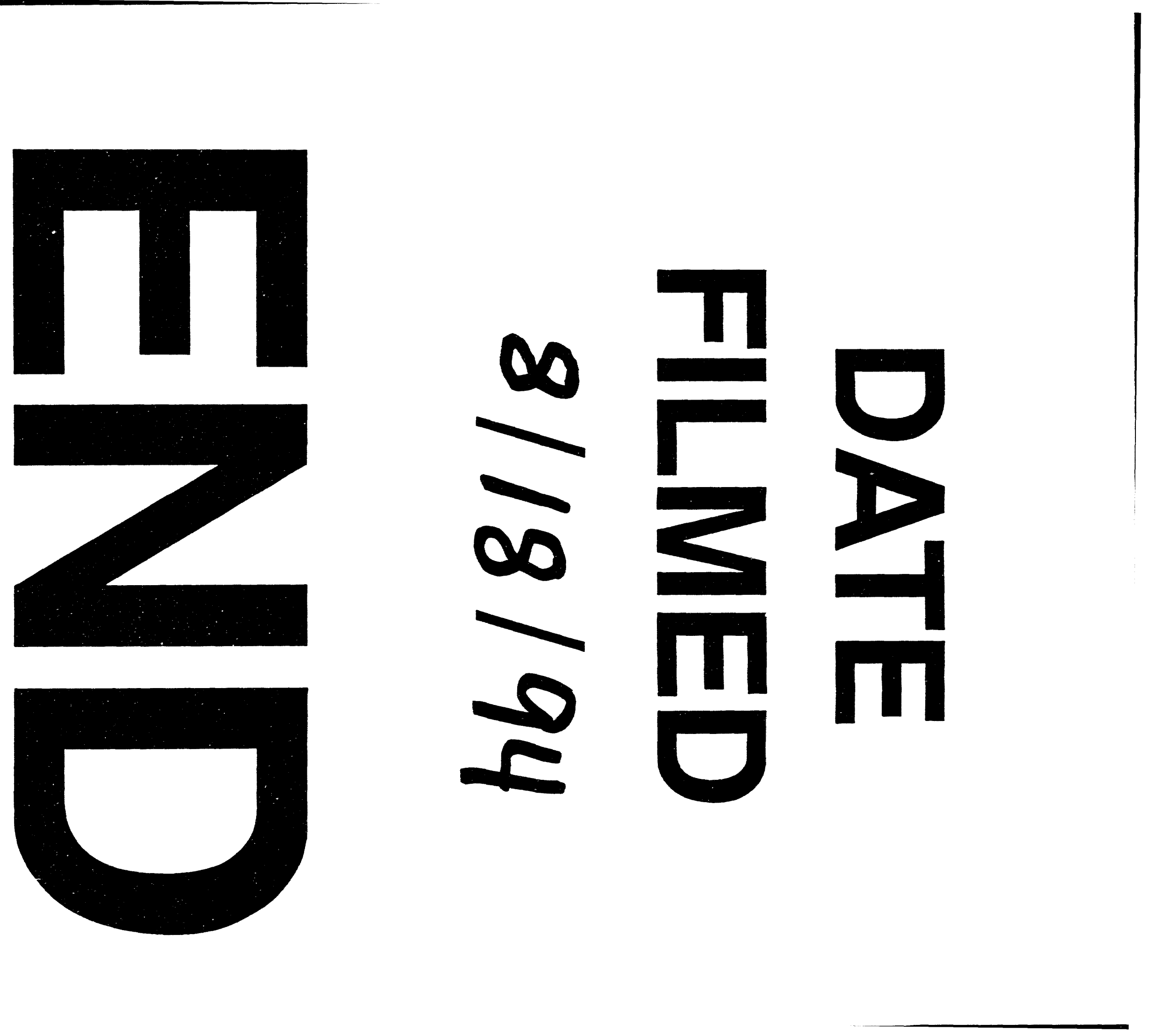
